
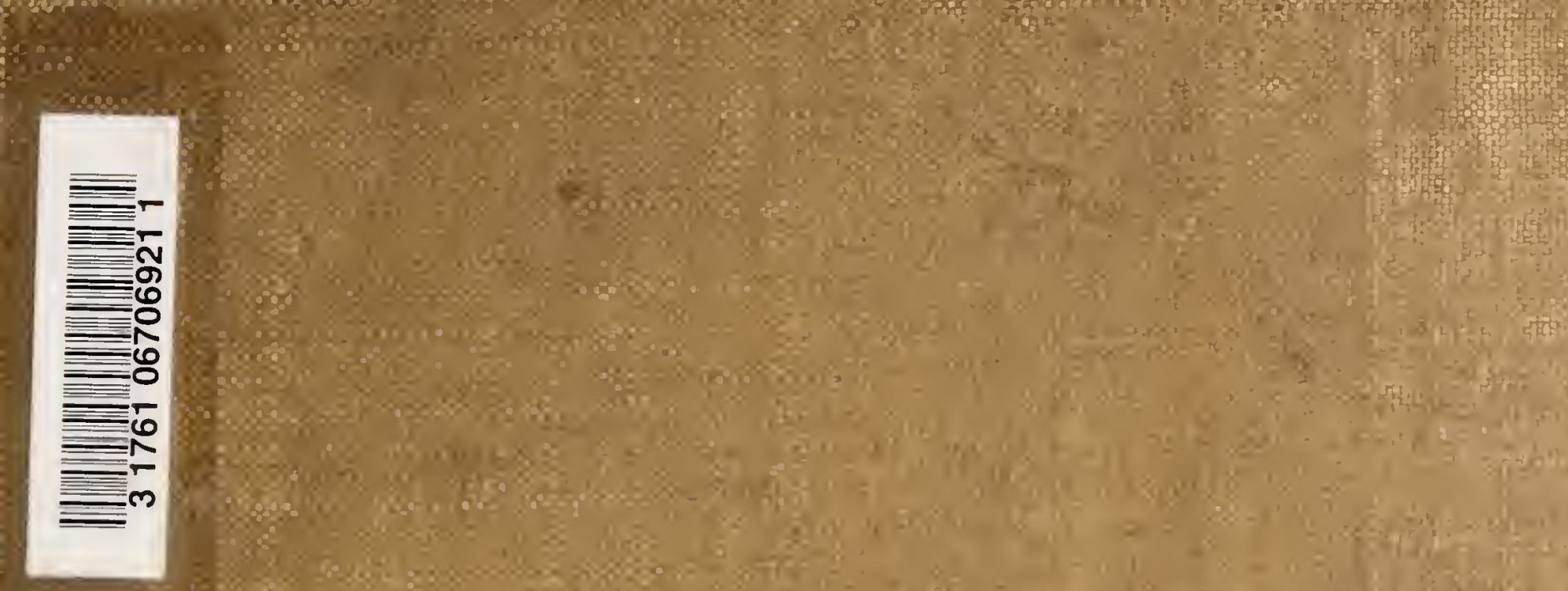

The

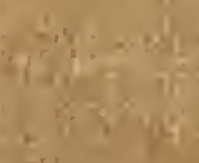

\subsection{0}

$x-4$

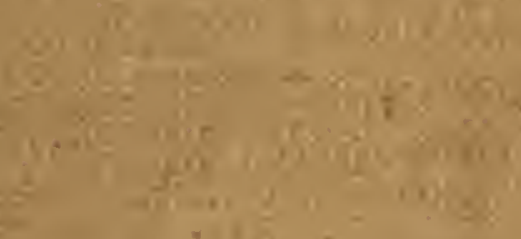

\section{(3)}

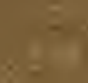
4.

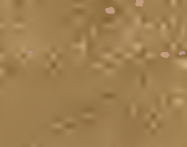
shing

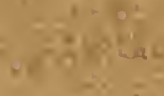

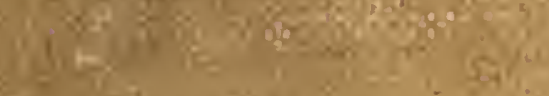

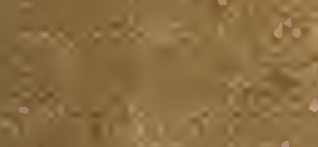

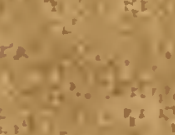

4 testar

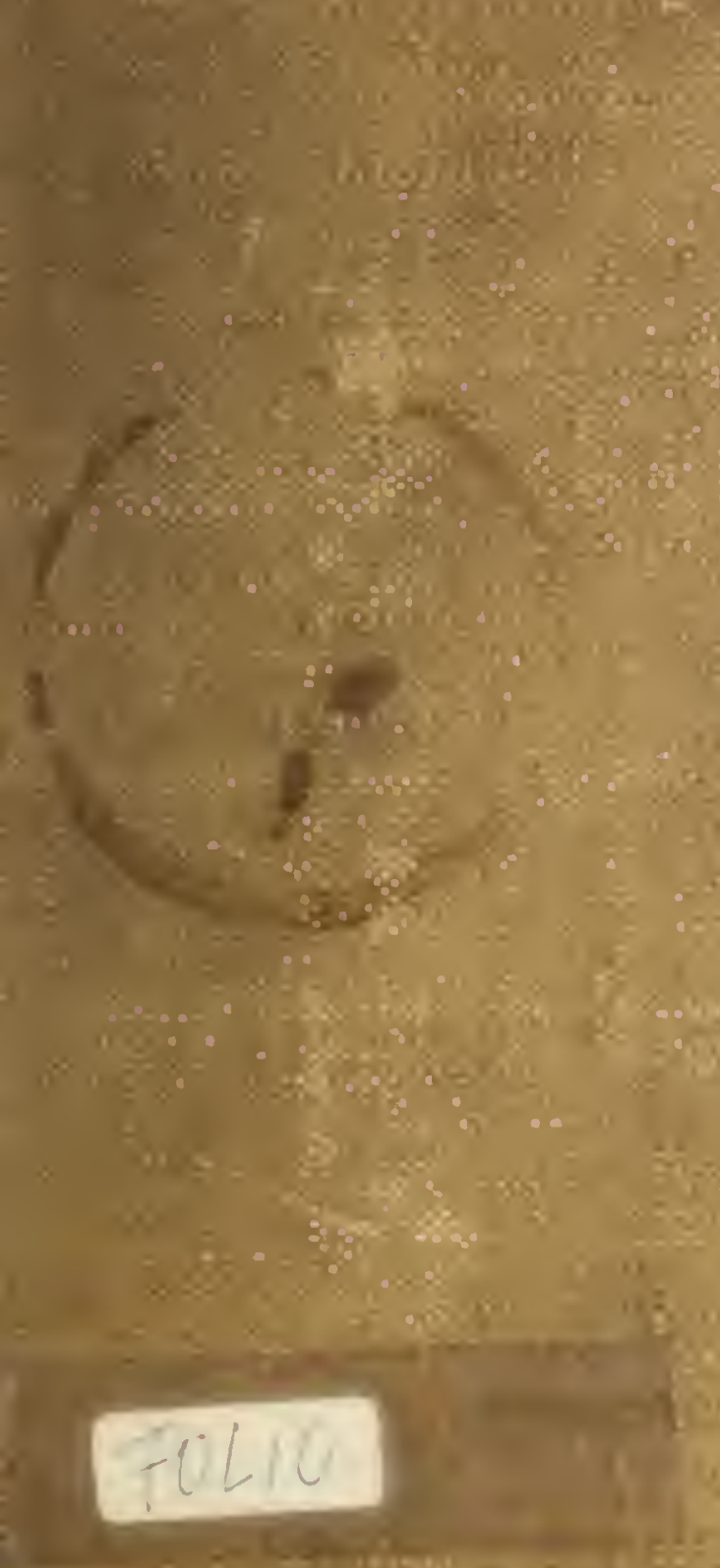

prosyits -

\section{8
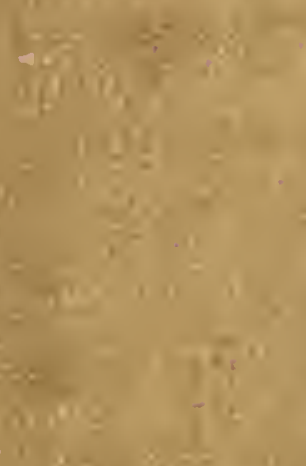

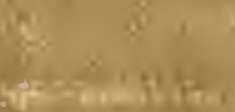

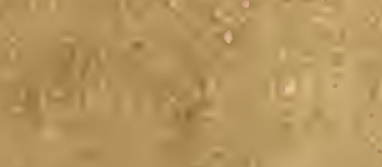

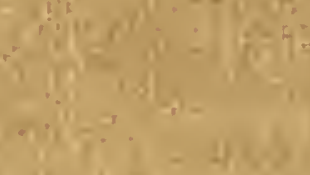

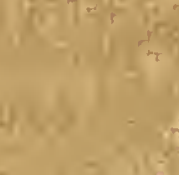

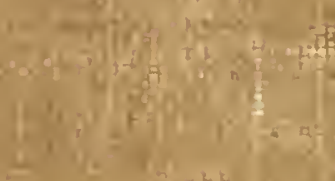

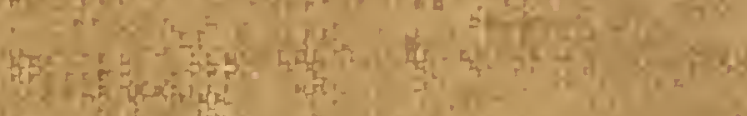

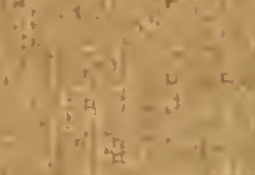

0
460
-100

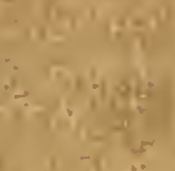

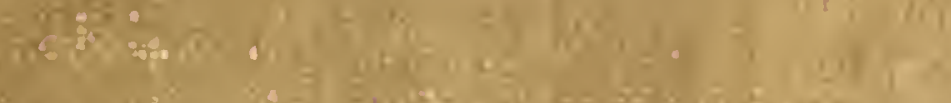

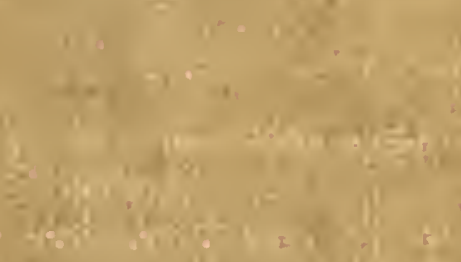

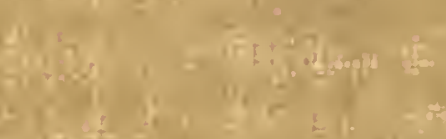
bic ati

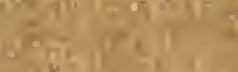
7:? : 



\section{Digitized by the Internet Archive in 2018 with funding from University of Toronto}









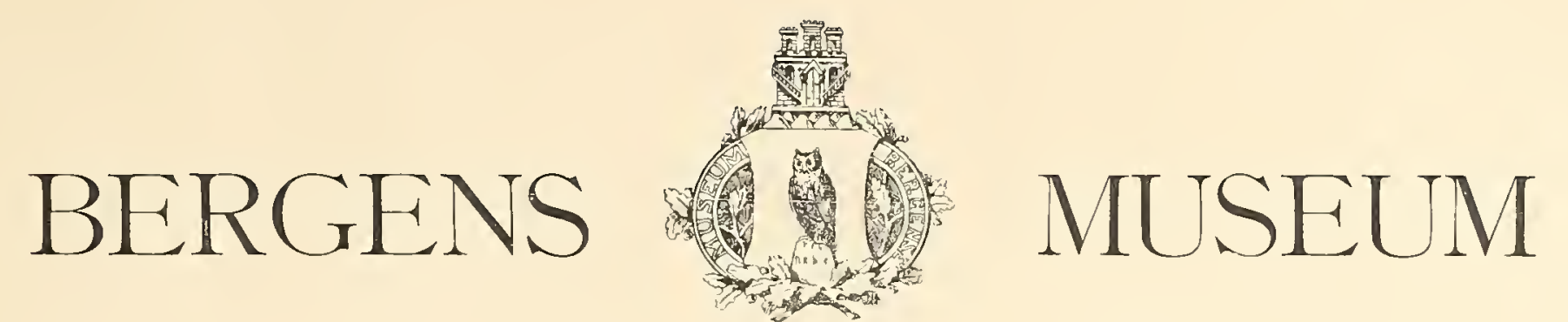

$-v-$

\section{ON THE \\ DEVELOPMENT AND STRUCTURE OF THE WHALE}

PART I.

ON THE DEVELOPMENT OF THE DOLPHIN

GUSTAV GULDBERG, M. D. ANI) FRIDTJOF NANSEN, PH. D.

BERGLN

PRINTED BY JOHN GRIEG

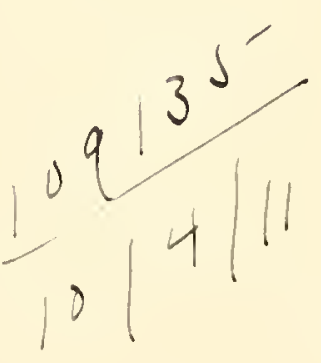





\section{Contents.}

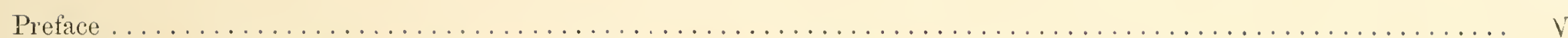

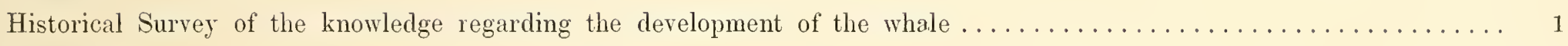

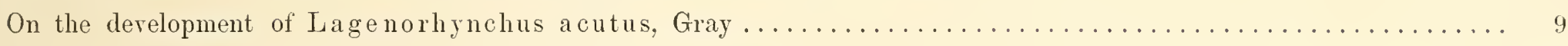

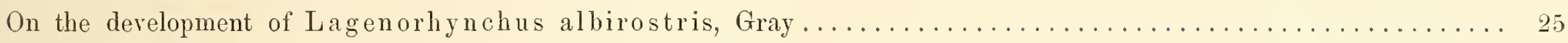

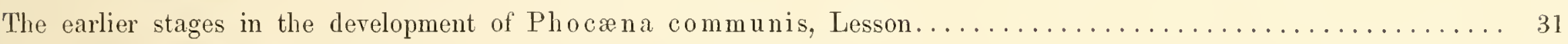

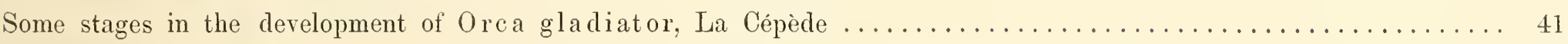

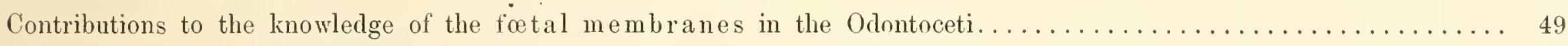

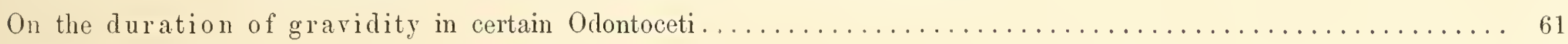

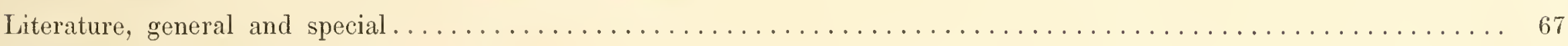

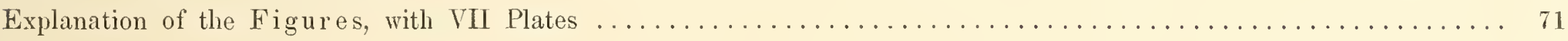





\section{Preface.}

It is now about four years since my friend, Dr. Fridtjof Nansen asked me if I would join him in a work on the fine collection of Whale embryos contained in the Bergen Nuseum, and which, to a great extent, Dr. Nansen himself, when curator of that museum, assisted by the curator, James Grieg, had brought together. As the committee of management were favorably disposed towards Dr. Nansen's proposal. I was quitc willing to enter into so interesting a labour, the more so from my having formerly been greatly interested in Cetacea.

In the autumn of 1890 , some small embryos of Lagenorhynchus acutus were sent to us in Christiania, where Dr. Nansen was also residing, having been made fellow of the University after his Greenland expedition, and keeper of the zootomical collection in the Royal Norwegian University of Christiania.

In the summer of 1891, I spent some time in Bergen in order to become better acquainted with the large collection of embryos and foetuses belonging to the museum there; and I would here offer my sincerest thanks to Dr. Danielssen ${ }^{1}$ ) and the officers of the museum, Dr. Brunchorst, Dr. Appellöf and James A. Grieg, for the friendliness and good will there shown me.

During the winter of 1891-92. Dr. Nansen and I worked together in the laboratory of the Anatomical Institution, studying more particularly the small embryos of Lagenorhynchus acutus, Gray. Later on, we had only occasional meetings for consultation about the work, as Dr. Nansen, being occupied with preparations for his North Pole Expedition, left it entirely to me. Dr. Nansen, as is well-known started on his Polar Expedition in June, 1893.

Owing to the numerous duties of my office, and to other calls upon my time, the completion of this work has been delayed for about two years, as I did not resume it until August, 1893. In the mean time. the material had been increased by the addition of a few interesting small embryos of Phocæna communis which I received from Greenland, through the Unirersity's Zoological Museum. In these I was able to show the existence of rudimentary lind-limbs. I spoke of this discovery and demonstrated it at the Anatomical Congress in Strasburg, on Nay 14th, 1894.

In addition to the species Lagenorhynchus acutus, L. albirostris, Phocæna communis and Orea gladiator, I have examined several embryos of Globicephalus melas and Dclphinapterus leucas, and to some extent Delphinus delplis. With the last three species, however, I have not dealt in this treatise, as its publication would thereby have been still further delayed.

Our special thanks are duc to the trustees of the Bergen Museum for the liberality with which the work has been got up, and to Miss Jessie Muir in Christiania for the care and labour bestowed upon its translation.

$$
\text { Christiania, July, } 1894 .
$$

G. GULDBERG. 

I.

GUSTAV GULDBERG

HISTORICAL SURVEY OF THE KNOWLEDGE

REGARDING THE DEVELOPEMENT OF THE WHALE 



\section{Historical Survey.}

$\mathrm{F}$ rom olden times until the beginning of this century, not only has the natural history of the Cetaceans belonged, as is well known, to the least familiar sections of zoology, but the accounts of this remarkable group of aquatic Mammals have been perhaps more than usually mixed up with additions of the imagination. Although Cetology, like so many other branches of biology, has grown considerably during the present century, we find its essential features already indicated in the by no means unimportant literature of the last century. John Hunter's must be considered as a fundamental work in this direction.

The older cetological literature presents many difficulties, and its value is in a great measure diminished on account of the great inaccuracy in the descriptions of the different Cetacean species, and the consequent difficulty and often impossibility in recognising them, whereby much confusion and many mistakes have arisen. This is, of course, very excusable, not to say natural, as both methods and material have been defective; but on the other hand, we have here a striking example of how misleading and disadvantageous is the desire in certain writers to cut up the genera - I had almost said, in a wholesale manner, -- into a number of species, thus manufacturing a diagnosis on the basis of defective material, without regard to differences of age and sex, or to variations, or only founded on anatomical (osteological) descriptions. It is not, therefore, until the later decades that a reliable specific definition - that first basis of all profound knowledge of any group of animals - has obtained a solid foundation in cetology; whereby also, it has become possible to identify several species which have been known and described in former centuries on the basis of numerous observations.

As was the case with so many other orders of the Mammal class, it was long before the Cetacea found recorders of the history of its developement, not through any want of interest in it, but because there was no material to be obtained. When I have named Eschricht, Anderson, Sir William Turner, and in later years Kükenthal, I have named the most important contributors. It would certainly be interesting if a complete literary survey of the history of the developement of the Cetacea and their biology from the earliest times could be made; for many a useful fact lies buried among the superfluous and useless matter which occupies so many pages in the old folios. I think, however, that the result, with regard to zoology, would scarcely be proportionate to the labour.

In here giving a short introductory survey of what is known about the history of the developement of the Cetacea, I ask that it may be criticised indulgently, as so much will remain incomplete and defective, the reason of this being partly that I have not had a sufficient quantity of literature at my disposal, and partly that I have not had the wished-for opportunity of working up the whole in the manner I had originally intended.

In the derelopmental history of the Cetacea, as in so many other fields of natural science, we find interesting facts recorded by that wonderful genius of ancient times, Aristotle, in which the general views of the philosopher, and the sober inquiry into details of the naturalist are combined in an exceptional manner.

In the 4th chapter of his first book, in which the propagation of animals is generally treated, Aristotle states that the Cetacea give birth to living young ones. In his second book (chap. 13 in the German translation, chap. 9 in the French), it is stated that dolphins have mammæ, and that these are not situated on the upper part of the body but by the regio inguinalis; they have not, howerer, as in quadrupeds protruding nipples, but a kind of opening on each side out of which the milk flows, the young one sucking as it swims by the side of its mother, as it has already sometimes been clearly observed to do. In the 6th book (chap. 11 in the French translation, chap. 12 [66-70] in the German) the propagation 
of the Cetacea is more fully treated of. We subjoin the following: ,The Dolphin. the Phalæna (Physeter?) and other Whales which have no gills, but a spouting-tube, give birth! to living young ones, as do also the sawfish and the ..bus" (le bœuf marin); for in none of these animals are eggs found, but from the first, germs (embryos) whence the young emerge by derelopement, as is the case with man and the riviparous quadrupeds. The Dolphin generally gires birth to 1 young one, sometimes 2; the Whalebone Thale to at most 2. which is most frequently the case, seldom 1; as with the Dolphin, so is it with the Porpoise (Phocæna) which has the appearance of a small dolphin and lires in Pontus, but is distinguishable from the Dolphin by its smaller size and greater breadth of back: its colour is dark blue. Many consider the Phociena to be a species of Dolphin. [All animals that hare a spouting-tube. breathe and draw in air, for they have lungs. The Dolphin has also been observed when asleep to hold its snout above water, and to snore in its sleep.] The Dolphin and the Phocxena hare milk and give suck to their young; they als, take their young into themselves as long as they are small. Ioung Dolphins grow quickly, for they attain to their full size in 10 years: they are pregnant for 10 months. The Dolphin does not bear at any other season than the summer. At the period of the dog-star, it hides itself for about 30 days. It accompanies its young for a long time and takes great care of them. It lives for a long time. and it is certain that many attain to the age of 25 and eren 30 rears; for fishermen have cut the tails off certain Dolphins, and let them go again, so that their age could be ascertained."

Other ancient authors. who mention the Cetacea, hare not been able to add anything of lasting value about these animals which was not knomn from Aristotle.

Galen (Kuhn's edition. Leipz. 1821) states that Whales, Seals and Dolphins breathe air (III, p. 444) and that Thales... have their eyes "on their long neck" (ibid. p. 631). He further states that the flesh is hard and unpleasant to eat, but may be eaten, if necessity requires, salted and spiced (VI, p. 728 and 737); also that eating whale's flesh occasions "sanguis melancholichus" (TIII, p. 13). ${ }^{1}$ ) Pliny, Oppian, Paulus Egineta and Tarro include the Cetacea in their description of other large marine animals, such as the Tumy, the Shark and others. Pliny has made himself conspicuous by the fables with which he has adorned the natural history of the Whale. Elianus and Plutarch also describe certain features of its natural history,

There are certain Arabian writers in the middle ages who are of interest to the history of cetology, as they mention some of the whale species among other wonders of the ocean.

In Abbé Renaudot's translation in 1718, of an old Arabian work: "Anciennes Relations des Indes et de la Chine rle deux Toyageurs Mahométans qui y allèrent dans le IX e. Siècle de notre Erre," revised and criticised by MI. Renaud, a large fish is stated to be found in the Indian Ocean, of which the size and width of the jaws is describer as enormous. Ships dread this fish greatly, and bells are rung to frighten it away. Much is said, too, about ambergris, which is cast up by the sea on to the coasts, also that it grows from the bottom of the sea like a plant. The word al-oual occurs as the name of a large fish. According to Renaud's critical remarks, the large fish in question must be a Cachelot (Physeter macrocephalus, L.).

In Edrisïs Geography from the year 1154 (translated from Arabic to French, by P. Amédée Jaubert, Paris $183 \pm$ it is stated that in the Gulf of Oman. in Indian Herkend, there is a lind of fish that is about : 200 feet long. "It is called el-waly; it is white." The translator interprets this as "la baleine" (in which case it is Eubalæna australis) and thinks that the words 'whale' and 'ITal' have come from the Arabic. In Dimichqui's Cosmography (from the latter half of the 13th century) ambergris is stated to occur in the Indian Ocean, and fables are related about its origin and effect; the stranding is also recorded of a large fish - probably a cachelot - on which 300 people lived for a whole montl. A fuller description of certain whale species is found in El-Kazwini's Cosmography. A "well-known genus of fish," 100 feet in length is here mentioned. which, by the aid of harpoons, is drawn to land and cut in pieces with axes, while from "the brain. a grantity of oil" is extracted. The Dolphin receives ligh praise as a "blessed animal" that helps those who are in danger of drowning. "Two other kinds are also described, called "Ketos" and "Kata", i. e. Whales, of which the first destroys ships, and the second is so large that bridges may be built of its ribs. "If leprosy be spread over with its fat, it disappear's with God the Almighty's help." The same writer also mentions the taking of whales — al iblênah (= la baleine) on the island of Irlandah; its young are hunted to procure "surl" (fat and lean). It is related that the young are born in the month Ilul (i. e. September' and are hunted from October to January, and the mode of capture is described as rery adrenturous. It is evidently the well-known mode of whale fishery practised by the Biscayans. In other respects, the aceounts of these Arathian writers are highly embellished, and any fresh items of information about the Cetacea will scarcely be found in their literature. ${ }^{2}$ )

In the time of the Renaissance, we find the famous Conrad Gesner as at distinguished author also in Cetology.

1) For the quotations from Galen I have to thank my honoured colleague Prof. Stenersen.

?) The above accounts of the Cetacea from Arabian writers have been obtained through my colleague. Prof. A. Steippel, to whom I would here offer my sincere thanks. 
This learned man, who was so well rersed in classical literature, quotes and criticises the accounts of these animal forms giren by older authors. In this way he has numerous quotations from Aristotle, Oppian. Pliny, Elianus, etc. for which reasou his great work will retain its full ralue from a historical point of riew; and as an original source. This edition also contains extracts from Belon (Petrus Belonius) and Rondelet (Guilielmus Rondeletius). The animals mentioned in his work. are, as is well known, arranged in alphabetical order, and most of them are also figured. Cnder the heading Delphinus, a grarid uterus with the embryo is figured. The Dolphin's anatomy is mentioned. also that the females usually give birth to one. occasionally two young ones, after 10 months gestation. The birth takes place in the summer. The fœetus is inclosed. in the uterus, in the chorion, the amnion, and the allantois: "sanguine nutritur per renas umbilicales, spiritum per arterias easdem trahit.... Coëunt delphini supinis partibus admotis mutuis amplexibus inhærentes, hominum more." A passage from Oppian is quoted in support of this (p. 383). Cnder the same heading a number of stories is related about the habits, disposition and intelligence of the Dolphin.

Among older writers in Northern literature, who have treated of Whales to any great length, Peder Clausson Friis (b. $15+5$ at Ekersund, Norway; d. 1614) claims a special mention. In his account "Om Fische," he gires an extract from the Royal Mirror (Speculum regale), in which the different species of Thales are enumerated and generally briefly described. The sperma of the Whale is moreover mentioned under "Huall-Raff". "which on account of its fat and the air which it contains, Hoats on the top of the water like froth." In his account of a whale-fishery; he relates that "when whales are at play, sereral may often run after one mother-whale." He describes a large Whale - probably a fin-backed whale. Balænoptera musculus - which was stranded in August 1532 at Thinemudt (Tynemouth?) (England). Olaus Magnus repeats the fact of the stranding of this whale. Olaus Worm (Museum Wormianum. 1656) translates into Latin the account of the different species of whales repeated by Peder Clauson Friis from the Royal Mirror ${ }^{1}$ ). Nothing further is related concerning the embryos of whales. These accounts of Whales and their habits hare probably arisen in a great measure from a gradual collection of the experiences of the fishing population of the coast.

Thomas Bartholin describes the anatony of the Porpoise, anatome tursionis, which may presumably be identified with our ordinary Phocena communis. In the presence of the Dano-Norwegian king; Frederick III and other spectators, he dissected a female Dolphin and its fœetus. He says: "The internal organs do not greatly differ from those in the human being." and he mentions the differences in his description. In the left part of the uterus he found a male fotus. with its head turned towards the mouth of the uterus (capite ad os uteri verso): the right part of the uterus was empty. He describes the umbilical cord with prominent quadruple ressels, and its dirision and disappearance in the sides of the placenta. His remarks on the placenta, amnion and allantois are worthy of notice: "Placenta exilis concreto sanguine similis, parietibus chorii agglutinatur. Tenuis amnios. Allantoides humores serosum continet, farciminibus inclusum."

In his anatomical description of the embryo, Bartholin pars special attention to the foetal openings and passages. such as the communications between the r. unbilicalis and the r. hepatica. the open urachus. the small supra-renal bodies. the testes with their connections, hidden in the abdomen, and the comnection of the membrum with the cartilaginous" hyoid-like" bone; the position of the heart beneath the ensiform process is moreorer mentioned, and its main foetal communications.

The works of Major (De anatome phocaence. . Ephemer, medico-physicarum annus tertius) and E. Tyson (The anatomy of a porpess. London, 168(1,40)2) also treat of the anatomy of the Porpoise.

Martens describes sereral species of whale, especially the Greenland Whale and makes a few remarks on the Nordcaper. With regard to the breeding of the Greenland Whale (pp. 103, 104) he only mentions that it gives birth to 1 or 2 young ones. and the author knows nothing about the duration of pregnancy. His attempt to make spermaceti from the semen of the whale (which at that time was a general supposition), strikes us as rather comical. Klein gires an account of the anatomy of the Phocæna, with special mention of certain muscles, and makes a ssstematic surrey of the different Cetacea. He took the holes on the embryo's upper lip, left by the hairs. to be organs of smell.

Johan Anderson repeats from the "unanimous assertions of Greenland whalers," stories of the pairing of Greenland whales in a perpendicular position in the water, both "sinking on to their broad, flat-lying tail-fins," with their heads pointing upwards, and embracing each other with their pectorals (swimmers). But at the same time he quotes P. Dudle $y^{\prime \prime}$ account (Philos. Trans. no. 387, Art. 2), which states that the female lies upon her back and bends her tail backwards. while the male passes orer her. They breed every other year, and the gravidity is said to last 9 or 10 months. A fœtus no more than 17 inches in lengtll, says Anderson, has the form of the species, and is white. They are 20 feet long when they are born. The young one sucks the maternal breast for 1 rear. There are illustrations of the Narwhal, and among them of a foetus. which, however, is unrecognisable.

Brisson's "Regnum animale" contains only a system, in which the Cetacea form one particular rlass separate from Fishes: while Linnæus, in his "Systema Naturæ". allows the Cetacea to belong definitirely to Mammals.

1) Mr attention was directed to the above literary particulars by Prof. Gustav sto rm, to whom I tender my sincere thanks.

9) These two authors I know only from extracts. 
Erik Pontoppidan, bishop of Bergen, among other things mentions (20 and 21 Bd. II. p. 228 ) the breeding of whales, repeating the statement of the perpendicular position of the animals in the water while pairing; that the new-born animal is from 8 to 10 feet long; that it sucks the breast of which the nipples are near the anus; and that the mother shelters the young one, when it is tired, beneath ler great pectoral.

Gunnelus, bishop of 'Trondhjem, gives a long account of the Phocæna (22. II, 1765, pp. 258-269) and the Orca (22. IT, 1768, pp. 99-112) but says nothing about their embryos or breeding. The contributions of these learner divines towards the natural history of the Cetacea is of considerable interest.

The find several observations in the work hy Otho Fabricius, which is of such importance to Arctic fauna. He quotes in lis "Fauna gronlandica" remarks on the hreeding and the young of certain Whales. 'Thus, he says of the pairing of Balienal mysticetus: "Corpore erecto, capite supra aquam prominente." It brings forth its young, generally only 1, in April. "The Balana boops (i. e. Negaptera boops) gives lirth to only one young one, but certainly not every year." The young one follows the mother until the next one is born. The Phocæna gives birth to one young one, which lieeps with the mother the first year. "Si gravida occiditur, ex utero cauda pulli prominens conspici solet. forsitan matre in angustiis parere conante." Of the Delphinus albicans (i. e. Delphinapterus leucas, Pall.) it is relater that it gives birth to only one young one which even in the fortal state becomes light-coloured, and when newly born is of a bluish colour, afterwards becoming gradually whiter, observations which have only lately been confirmed.

J. G. Schneider's critical collection. from his own and older times, of accomnts of the natural history of the whale. is also important to the atrance of Cetology in the last century. He relates the usual story about the pairing of the Greenland whale. adding also Dudley's version. which hats an appearance of greater probability. Pairing takes place only erery other year, and only one young one is born. A fixtus is meritioned that was 17 inches long, and of a white colour: the new-born animal is black and generally $20 \mathrm{ft}$. long. Pregnancy lasts from 9 to 10 months. and when the mother gives suck to her young, she lies on her side in the water. Ho gives full accounts of the other whalebone Whales that were known in the last century, critically sifting their literature. He also gives a survey of the then known toothed whales, among which the Carchelot takes a conspicuous platee. Minor anatomical rematks are added; and he gives a representation of the common Porporise, based upon personal observation. Schmeider's work gives valuable information for the study of the cetological literature of the 18 th century.

While John Hunter, in his fundamental work on the organisation and habits of whales, enlarged the knowledge of these ocean-mammals. and brought a stronger light to bear upon them, it did not fall to his lot to make obserrations on their embryos and developement. On the other hand, he treats fully of the anatomy of the organs of generation.

In the beginning of the present century we find, as an eminent cetologist. Lacépède, who describes and figures, in his well-known "Histoire Vaturelle des Cétacés", a number of Cetacean forms; we are, as is well known. indebted to him for the separation of the genera Balina and Balanoptera. He does not, however, state anything new about the breeding and developement of whales, though he describes in vivid colours and with the pen of a Buffon, the habits of these animals.

Somnini. a contemporary of Lacépede but not of the same importance, who continued Leclerc de fBuffon's great "Histoire Naturelle". describes the Cetacea. the different species known at that time, their different anatomical relations, especially of Baicena mysticetus. its habits, propagation, etc. He gives attractive descriptions in fine language from the best sources of that period, though he also produces much that is false. A much greater interest in Cetology seems, however, from this time to have been awakened in the prolific French zoologists, and has borne good fruit in the cetological literature now to be mentioned.

The accounts of the Gaing-whale, and its capture in particular, given by J. Landt (2t) and H. Chr. Lyngloye (26. pp. 204-232) are of subordinate interest. Lyngbye mentions that young ones are often found in the Caaing-whale when cut up; but they differ very considerably in size, large embryos having been found at all times of the year, from which lie infers that the Caaing-whale breeds at any season of the year. It gives birth to only one young one.

A cetological writer of some mark, William Scoresby, describes, both in his "Account of the Arctic Regions" and his ". Toumal of a Toyage to the Northern Whale-fishery," ete, the appearance and habits of several Arctic Whales, and among others gives a full description of the Greenland Whale, with which, from abundant experience, he was best acrutinted. "The pairing," he says "lass often been observerl in the latter end of the summer, and the young one is supposed to be born in Felnuary or March." It is added that at the end of April 1811 a young one with umbilical cord was captured.

"The young one at the time of parturition is said to be at least 10 , if not 14 fect in lengtir. It goes uncler the protection of its mother for molably a year or more, or mutil by the evolution of the whalebone, it is enablerl to procure its own nourishment." He also gives in excellent drawing and description of the Narwhal. and describes several Balsenopteridie, Hhobephalus and Behugat. Scoreshy's work has still a great interest for Cetology, notwith-tanding that he was the originator of the well-known mistake about the Nordcaper. a mistake which was long maintaned under G. Cuvier"s authority.

Lesson. whose name is renowned in Cetology, describes in his "Histoire Naturelle des Cétacès" both the herbivorous 
Cetacea and the whales proper, their habits and anatomy, as far as they were then known, being shortly treated of. Concerning their breeding he says (p. 17T): "Les femelles des dauphins reçoirent dans l'accouplement les mâles en les serrant entre leurs nageoires. On dit que la gestation est de dix mois, et que la conception a lieu dans l'automne; on assure aussi qu'elles ne font qu'mn petit ou deux à chaque portée, et que la mère surreille arec sollicitude leurs mourements, les façonne ou les habitue à la natation .. . Ce n'est qu'en se penchant sur le côté que les jeunes dauphins saisissent le namelon du sein de leur nourrice, et qu'ils y puisent un lait onctueux, de couleurs bleuâtres, mais très-nourrissant."

In the well-known "Medicinische Zoologie" by Brandt and Ratzeburg, where Physeter, Balæna and sereral other Cetacean genera are described with special reference to their outward form and skeleton, and to the products they yield which are used in medicine, nothing new is found about the graridity or the embryo of these animals.

Georges Curier has also rendered great services to Cetology, notwithstanding the mistakes he has made on certain points, e. g. the geographical distribution of the Greenland whale. With his critical ability and thoroughness he brings order into the numerous descriptions and the confusion of names, searching for literary sources, and procuring osteological signs for the identification of the species. His works are therefore of considerable ralue with regard both to the systematism and anatomy of these animals; but it did not fall to his lot to contribute any fresh facts about their breeding and derelopement.

Nor does F. Curier, in his well-known "Histoire Naturelle des Cétacés," seem able to extend the knowledge in these particulars, for he says (p. XXIT seq.): "On ignore d'accouplement des Cétacés souffleurs. Personne jusqun'à présent n'en a été témoin. Liopinion la plus probable, c'est qu'ils sunissent couchés tous deux sur le côté . . . On ignore aussi la durée de la gestation que quelques-uns portent à dix mois pour la baleine, dont le jeune, en naissant, aurait ringt pieds de longueur." He then enters into the subject of suckling. After describing the different Cetacean forms, - certain of the descriptions being undoubtedly based partly on autopsy, - he gires in conclusion a good. though scarcely complete list of the literature on this subject.

In the first half of the present century, we find a number of cetological treatises, some of them descriptions of stranded specimens. others. anatomical pamphlets. Inquiry seems to be trying to make up for the prerious neglect of these giant organisms of the world. While there hare appeared as we have seen, large collections of accounts of the true and the herbirorous Cetacea in French zoological literature, we find on the English side a number of special descriptions following John Hunter. Contributions to Cetology hare also been made by German naturalists, the Phocæna communis haring been taken as the model, and in the main furnishing material for special descriptions.

We find an eminent explorer in the field of Cetology in Rapp, who in his well-known little book, "Die Cetaceen zoologisch-anatomisch dargestellt" 1837, has recorded the outlines of the anatomy of these animals, based upon careful obserration and thorough study; while besides the addition of fresh information, he critically sifts the already existing material. He had not, howerer. an opportunity of becoming acquainted with Cetacean embryonic forms. He states that he found in the umbilical cord of a Phocena 2 arteries and 2 reins; and that the urachus seems to be open until the birth of the young one. "Leber die Fötushïllen der" Cetaceen fehlt es an Beobachtungen." he says. quoting frcm E. Home the statement that the chorion takes the place of the placenta, as in the sow and the mare.

Nor has Karl Erust ron Baer. in his famous work "Leber Entwicklungsgeschichte der Thiere," much to say" about the developement of the Cetacean trpe, for he states that he knows nothing about the orum of the Cetacea. but that he believes, from the remarks made about it in literature, that no placenta is formed, and that the orum shows conditions similar to those in the Pachydermata. He has only had the opportunity of seeing one embryo 9 inches in length. - a narwhal, whose navel string had only a single umbilical rein, a fact which he emphasized in contradiction to Rud olph s observation of 2 umbilical reins in Phocæna.

Towards the middle of the present century a new era in cetological investigation begins with the production by the well-known Danish naturalist D. F. Eschricht of a series of works on Whales, based on studies of embryonic forms. Part of his material was obtained from Bergen in Norway - where for centuries captures of Balænoptera rostrata and some species of Dolphin have been made, - and part from the now-existing Danish colonies in Greenland. We thus find in Eschricht for the first time, a more detailed description of some large and small embryos. In addition to Balœnoptera rostrata. the embryonic forms of Megaptera boops and Hyperoodon diodon and their anatomy are described. In an earlier work. from 1837, he has described the fœtal membranes in a grarid Phocena. In Eschricht and Reinhardt's well-known monograph on Balæna mysticetus, L., the subject of the duration of its gestation is also touched upon. Eschricht directs the attention of inrestigators to embryonic forms as a means of learning to know many of the conditions in the full-grown animal. This is due to the circumstance that the Whale embryo rery early assumes the generic and specific characters, - a fact which is clearly shown in the present treatise.

Although embryonic forms are only occasionally mentioned by more modern anthors. - their size and dimensions being generally given in conjunction with descriptions of full-grown animals, - we hare contributions to the knowledge of the fortal membranes in the Cetacea. from Owen, C. D. Meigs and Rolleston. It is to the eminent naturalist Sir IIilliam 
Turner, however, that we owe a more intimate acquaintance with the foetal membranes in Cetacea, his important work forming the foundation for future inrestigation in this field.

A detailed description of both embryo and foetal membrane is given by John Anderson in his monograph on the tropical genera of Dolphin, Orcella and Platanista. Further investigation of the placentation is made by Beauregard and Boulart, and Chabry and Boulart, who mention an embryo of Delphinus delphis, s5 centim. in length, its position and the futal membranes. Klatsch describes the foetal membranes of the Phocana communis very exactly, and a very clear description of the placentation in Cetacea as compared with that in other Mammals, is found in Max $\mathbb{W}^{\top} \mathrm{ebe} \mathrm{r}^{\prime} \mathrm{s}$ interesting work, "Studien üher Säugethiere", in which the relations of the Cetacea to other Mammals are treated rery thoroughly.

When we add G. Guldberg's study on gravidity in fin-whales, and P. J. van Beneden's valuable "Histoire Naturelle. of Balæna, Megaptera, Ziphoides and Delphinidse, _ in which a few remarks on the fotus and placentation occur, - and Kiikenthal's large and important works on the anatomy and developement of Cetacea, the most important contributions to Cetology in the last decade have been named.

As a consequence of the ruling tendency in biology in the divection of the theory of evolution, the question of the phylogeny of Whales has of course been discussed. It was especially Sir H. Flower, - whose investigations in Cetology have earned such merit. - who. about 10 years ago, made this a buning question, earlier naturalists, such as Huxley. Iacalister, Marsh and others having only touched mpon it; while the famous P. J. van Beneden, in numerous treatises has left valuable material for future comparison. Most of them place the Cetacea in comnection with Pinnipedia, a theory which is specially expressed by Ch. Julin. while Max Weber does not take his view, but treats exhaustively of the probabilities and affinities between the Cetacea and other Mammals. John A. Ry der takes up a peculiar position in holding that the flukes of the tail-fin are homologous to hind extremities (52. p. 482). "The structure of the pinnipeds indicates that the process by which their hind limbs were directed backwards and partially included together with the tail in a common integumentary investment, would, if exaggerated, lead to the translocation and fusion of the feet with the end of the sides of the tail. as in the Cetaceans, in which the now degenerate, backwardly-displaced feet are represented by the thukes." Ryder has been strongly opposed by Kïkenthal. 'The skeleton of the Cetacean's fore-limb is of course of great phylogenetic interest, and has therefore been deeply studied and utilised in that direction, chiefly by Max W eber and J. Ryder, Leboucq, who has made considerable contributions, and P. Alblecht, and .J. F. Brandt, who takes up a peculiar position. But above all Käkenthal has studied "die Cetaceenhand", and las thereby gained lasting merit, having had very considerable embryological material at his disposal. In addition to Weber, Kükenthal has also given special attention to the question of the Cetacean's position in relation to other Manmals, and whether, according to Flower they must be considered as derived from more primitive Mammals which have titted themselves for an aquatic life like the Sirenia and Pinnipedia, witlout standing in any phylogenetic connection with these animals. In Kïkenthal's important work of 1889 he treats of the skin of Cetacea. their hand-skeleton, and, in conjunction with I'l. Ziehn, their central nervous system. In lis work published in 1893. which contains a miss of facts. Kiikenthal treats of the developement of the external form of the body, and the structure and developement of the external organs the integument, tail-fin, dorsal-tin, pectorals and the formation of the lip, with their functions, the nose, the external ear and mammary organs), and lastly the developenent of the teeth in the 'Toothed Whale, and their absorption in the Whalebone Whale.

Of late years, new light has been thrown upon the palæontological position of the Cetacea by an important work on "leuglodon", by professor WT. Dames, who establishes 3 sub-orders of Odontoceti, viz. (1) Archacoceti, (Zeuglodon), (2) Mesoceti (Squalolon). and (3) Euodontoceti (the recent Odontoceti).

Though it might be rery interesting to make more copious extracts from different works with regard to the phylogeny of Cetacea. and reflections upon them, I slaall not, for the present, enter more fully into the subject. In the following investigntion, I shall touch mpon certain sides, of this question. What I wish to give in/ this treatise is an account of the ontogeny of some Odontocete species as far as material will permit, and hope by this contribution to fill up a small part of the lacuna which the ontogenic developement of the Cetacea permits us to open up. Certain fresh facts throwing liglit upon the futal membranes and the gravidy of Odontoceti will also be added. 
II.

1.

GUSTAV GULDBERG AND FRIDTJOF NANSEN

\section{ON THE DEVELOPEMENT}

$\mathrm{OF}$

LAGENORHYNCHUS ACUTUS, GRAY.

PL. I-III,

AND LETTERPRESS FIGS. 1 AND 2. 



\title{
The Developement of
}

\section{Lagenorhynchus acutus, J. E. Gray, 1828.}

\author{
Plates I-III.
}

$\mathrm{T}$

his species of dolphin, so frequently met with on the coasts of northern Europe, was, as is well linown, described by J. E. Gray as early as the year 1828. His first description of the animal was not, however, rery accurate, and occasioned misapprehension. A more detailed description appeared later (1846), and since that time both the skeleton and the external form of the animal have been the subject of numerous investigations, e. g. by Schlegel, Rasch, Van Beneden, Lilljeborg, Sven Nilsson, Malm etc., the same species having been represented under different names. After Flower's careful inspection of the specimens lying in different museums, it may be looked upon as certain, that Schlegel's Delphinus Eschrichtii and Rasch's D. leucopleurus are indentical with Lagenorhynchus acutus, since I cannot but agree with True (85) in thinking that Schlegel's statement of the number of vertebræ - namely 91 - must be incorrect. According to True, Prof. Cope's L. perspicillatus and L. gubernator are also identical with L. acutus, a theory which Liitlen (82) also advances.

Concerning the occurrence of this species on the coast of Norway, Prof. Collett (79) has made several notes, from which it appears that both in the last and in the present century, there have been large and small takes of this species. It is necessary, howerer, to be cautious in identifying the species from the reports of fishermen and others, as the name certainly raries with the locality. For instance, in south-eastern Norway, the species in question is called "white-side", but "springer" on the west coast (according to James Grieg) where the fishermen frequently call L. albirostris "white-side."

Prof. Rasch's account of the shoal near Drobak in the Christiania Fjord, in June, 1842, when 22 specimens were taken, is well known in cetological literature. Of these 22, 4 were females, one of which had mill in the mammary glands, though no embryo was observed. The males in this species, as in L. albirostris, are on an average larger than the females. The one figured by Rasch measured 2.630 metres, and a female measured by the same author was 2.310 metres in length; but these measurements were made, according to Rasch's own statement, from the front of the lower jaw to the extreme point of the tail, and not to the cleft in the tail where the back-bone ends. F. W. True gires the length of this species as 2.515 metres.

On the 9th Nor. 1885, a remarkably large catch was made at Torskøen, Manger, some miles north-west of Bergen, by which Bergen's Iluseum obtained a hitherto unsurpassed collection of enbryos, a number of skeletons, etc. also being preserved. It was Dr. F. Nansen, at that time keeper of the Bergen Museum, and keeper James Grieg in Bergen, who preserved this expensive and valuable collection.

Embryos of this species had previously been briefly described by Gray and Lütken. The former (76, p. 274) mentions an embryo preserved in the British Museum, which came from the Faröe Isles; he does not, howerer, state its length, but mentions the 6 foetal hairs on the upper lip.

Prof. Lütken (82) in Copenhagen has given detailed measurements and, to some extent, description of two foetuses, one 370 millimetres, and the other 485 millimetres in length. He also mentions one 820 nmm. long from Greenland, which he supposes to be L. acutus, and not albirostris, under which name it has been represented. Kükenthal (58) mentions in his great work, a foetus $41 \mathrm{ctm}$. in length, of which the skin-colouring is briefly described, and one $45.5 \mathrm{ctm}$. long, whose hand-skeleton has been subjected to comparative examination.

Being in possession of so complete a collection of embryos of this species in different stages of developement, we will here give a series of descriptions of the developement of this Odontocete from the earliest at present known embryonic Cetacean forms, up to the almost full-grown foetus, considering principally the external form-conditions.

I. The smallest Lagenorhynchus embryo (Tafel I), found in the collection at our disposal, measured 8 mm., without doubt the smallest Cetacean embryo hitherto examined. The whole egg, (Pl. VI, fig. 1) which was preserved entire, measured 75 mm., 
and in it the embryo lay inclosed in its foetal corerings. These foetal membranes will be more fully treated of elsewhere, suffice it to say here. that the little fuetus was closely enveloped in the amnion. (Pl. VI. figs. 2 and 3).

On a closer examination of the external form of this embryo, it unfortunately proved to be very much deformed and injured. especially in the anterior: more pointed end (Pl. I fig. 1). The external form of the head could not therefore be determined. nor was any indication of either fore or hind extremities observable. On the other hand the eonvex surface of the back was distinct separated from the injured front portion by a sharp furrow. thereby giving prominence to the more rounded back part of the trunk. At the posterior end was observed a blind fossa underneath, rentrad of the tail. The tail was plainly to be seen lying in folds, and bent upwards against the rentral surface. In front of it, the remains of the umbilieal cord might be observed (fig. 1. u.).

On looking at the rentral surface of the embryo, it proved to be injured to such an extent, that no clear idea of its external form could be gathered. On the other hand, with regard to the posterior end of the body, there could be traced a long. relatively well-developed. cylindro-conical tail, lying in a sigmoid curve: and in front of it the remains of the detached narel forming an irregular oral surface (Pl. I. fig. 2 c and u).

In riewing the embryo's right side (fig. 3), there are no exact particulars to be gained of the shape of the head, visceral cleft, etc.. so that only rague conjectures can be made. Remains of the umbilical cord and the enlargement behind it (u) may be seen. The hinder part of the body here too, appears smooth and uninjured. The hollow at the posterior end together with the cylindrical tail are noticeable.

Tn a dorsal aspect. the furrow separating the injured from the uninjured parts is to be clearly seen; the body tapers towards the end, where the tail is bent forward against the rentral surface. The body does not appear to be stmmetrical, a fact which must doubtless be attributed to a deforming sigmoid curvature in the long axis, and which is confirmed by the longitudinal sections made.

How far this may be a normally-developed embryo seems doubtful after external examination. The injury to the fore part of the embryo, especially the head, may perhaps be attributed to a too great shrinking caused by the preserring fluid, and consequent great deformity and partial breaking away of the epidermis. This, lowever; is only partly confirmed by a microscopical examination, which rather points to an interupted developement, with already commenced degeneration. The possibility of cadareric changes may; on the other hand. be almost excluded. as the specimen was preserred fresh. I have had good opportunity of ascertaining that the deformity of. and injury to the front part of the body were not due to its preparation being commenced after hardening, as the opening of the amniotic bag was made from behind and on the back, so that in any case, the injuries, if any, could only have been slight and superficial, caused by the instruments during this process.

Drawings of the embryo were made by Dr. F. Nansen (Pl. I, figs. 1-4). As the examination of the external form in this specimen could lead to no further explanation or information, it was coloured in borax carmine and imbedded in paraffine, and microtomised in longitudinal sections (162 sections).

On examining the sections with a low magnifying power (Zeiss, obj. aa oc. 2, drawn with an Abbes camera) it appeared, as before. that the fore part of the embryo was exceedingly deformed, and had also, as regards the histologieal structure, undergone a degenerative change. The immediate impression received is that a deforming, retrogressire change has taken place, in which the listological elements have been injured.

It is. however, noticeable, that this histological change principally affects and is most marked in the anterior part of the embryo, corresponding with the facts apparent on external examination.

When the sections are examined with a low magnifying power, the segmentation of the convex, dorsal parts of the body becomes more and more distinct, the nearer the sections approximate the median line. The protorertebræ, or mesoblastic somites (Pl. I, figs. 5 and 6, Seg) reveal themselves partly as a closer, more undifferentiated mass of cells which, in many sections, especially in the dorsal region, are separated by the embryonal connective tissue with elongated cells and a clear, homogeneous ground substance, partly by the appearance of an incipient cartilage formation, in the shape of short, true cartilage vertebrx. Fragments of the chorda dorsalis are seen in many of the sections (fig. 6, ch). I was able to count more than 10 segments. The segmentation of the tail part was not complete. Tafel I, fig. 5 shows the segmentation of the lateral region outside the medullary tube, while in fig. 6 may here and there be seen longitudinal sections of the chorda. the clear lines arranged in rows representing the incipient cartilage rertebræ.

The outline of the medullary tube (fig. 6, med) is distinctly seen. but while the elements constituting it hare, in the fore part. the appearance of a shapeless mass in which no distinct cell elements are to be discovered. there may be found in many places in the hinder part that corresponds with the embryonal body's uninjured portion, distinct epithelial cells, arranged to some extent in rows, but always rather curved, with many artificial lacunæ. In the fore part of the embryonal body, enlargements of the medullary tube may be plainly seen. which are most naturally interpreted as the embryonal brain resicles (fig. 6. ch). In a few sections situated laterally as regards that represented in fig. 6, there is a smaller brain resicle 
enlargement, lying in front of the foremost in fig. 6 ; the contents and walls, howerer. of all these brain resicles are so misshapen that no distinct cellular elements can be distinguished. While it is scarcely possible, from the specimen under consideration. to declare with certainty whether this laterally-situated brain vesicle enlargement in the fore part of the medullary tube is the primary anterior or the secondary anterior brain vesicle, the cerebral hemispheres resicle, or possibly the not yet invaginated optic vesicle (which, however, secms to me to be rery improbable). I bclieve that the foremost enlargement of the medullary tube in fig. 6. cb. should be considered as the mesencephalon. The clongated part lying in the rear would then have to be taken for the myelencephaton and its continuation in the spinal cord.

If that part of the mesoderm tissue in the brain region. which lies on the rentral side of the medullary tube be carefully examined. a dorsally-projecting. conical process is at once apparent, forming the posterior bourdary of the mesencephalon, and separating it from the parts lying behind. This projection I consider ought to be interpreted as Kölliker's hindmost "Schädelbalken": while one in front of the foremost brain vesicle enlargement in fig. 6 ought to be taken for Kölliker's "vordere Schädelbalken" (Rathke's "mitlere Schädelbalken"). This explanation is supported by the numerous proto-rertebræ lying behind, which attach themselves entirely to the rest, only that they lie somewliat close together, and that directly below (rentrally) lie the aorta and heart, so that we are only justified, from these relations, in considering that part of the medullary tube lying above as corresponding to the neck region.

The fact that the proto-vertebræ, the chorda dorsalis and the medullary tube appear in the various sections with a maximum and minimum of distinctness in different places. is owing to the subjection of the embryo s axial skeleton with the medullary tube to side compression. The median line of the foremost brain resicle is thus met with long before the lindmost. and about simultaneously with the median line of a part of the back. There is thus without doubt a double sigmoid curve of the long axis. Moreover, the sections do not fall exactly in the sagittal plane, but intersect it at an acute angle.

The integuments (Pl. I, fig. 8) show a purely embryonal structure, namely, the epidermis like a single-layered, low. cubical epithelium, and the corium, as a very undifferentiated mesodermic tissue.

The large. long fissure in the fore part of the embryo (fig. 6, F.t.) I interpret as the fore-gut. In one or two laterally-situated sections, a few enlargements are observable, perhaps due to artificial compression. No mouth is to be discovered.

Below the fore-gut, a triangular region is seen (fig. 6, cor), which may be explained as the heart; in a few sections the embryonal blood corpuscles can be seen in it: the walls are also visible. In some of the sections the vena umbilicalis is visible, and can be traced from the umbilicus and seen to open, in front of the liver, into the heart.

Behind the heart, separated by a bridge of mesoderm-tissue, is a larger oval object, to be recognised as the liver; numerous blood-ressels are visible. and between these, large epithelial cells, which here and there form a lumen (Fig. 6 and 7 hep.).

In a few lateral sections, beneath the proto-vertebre, above a fissure (fig. 6. t) which I have interpreted as being an intestinal lumen (?) can distinctly be seen the Wolffian bodies, with passages, numerous blood-ressels, and a single glomerulus, although the whole example is rery indistinct.

In the description of the external form, there has already been mentioned an invagination situated ventrad of the tail, and seemingly blind. This cavity can be traced in some sections to the side of the medial plane (fig. $\overline{7}$, a) where the form of the anus is distinctly seen. The adjacent portion of the intestines is, on the other hand, not visible. The surrounding, strongly-coloured. granulated parts here denote quicker cell-proliferation.

The histological elements in this hinder, less injured part of the embryo possess, however, a certain peculiar character which cannot be designated as quite normal. The boundary between the different organs is slight. and the whole example, as represented by the diffcrent sections, is somewhat obscure.

If we sum up the discoreries now before us after the examination of this 8 millim. long embryo, they scarcely admit of a doubt that it is an embryo at a very early stage of developement. Had it been entirely uninjured, the visceral arches would rery probably have been found, and the first slight indication of anterior extremities. while the perforation for the mouth aperture could scarcely have been more than in its commencement. The external form of the trunk has certainly been giren with broad navel. The ahready long tail, although in its embryonal form. may yet be noted as characteristic. In the embryo of a quadruped in a stage corresponding to this, bud-like indications of the extremities might well have been expected; and similar conditions would also, in all probability, have been found here. As reliable points of comparison with other animal embryos, there are the purely embryonal integument, the first indications of a cartilage formation, and the scarcely complete segmentation of the extreme end of the tail. I must, however. characterize this embryo as abnormal, as it has been undergoing a retrogressive or degenerative process. Certain portions of the foetal membranes also point in this direction, as they show distinct adrancement, while the embryo is in a state of retrogression.

Haring a short time ago obtained a rery small embryo of Phocena, of which the form was remarkably well preserved, and is to be described subsequently, I have been even more strengthened in my opinion that this 8 millim. long 
embryo of Lagenorlynchus acutus has commenced a retrograde-degenerative developement. supervening soon after the medullary tube with the brain resicles and the more important organs hare been formed. It is also somewhat remarkable that a fœetus so small, and which could hardly have been more than 4 weeks old. had it been normal, should be found coexistent with one 100 millin. in length.

II. A far more adranced condition of developement than the foregoing is shom in the $26 \mathrm{millim}$. and the 30 millim. long Lagenorhynchus embryos, which resemble in a remarkable degree embryos of other orders of mammals (Tafel II, tigs. 1-8). Eschricht delineates a Beluga embryo about 30 millim. in length. and Kükenthal describes an embryo Porpoise 25 millim. long. both of which are in about the same stage of developement as the 26 millim. long embryo here described. The measurements give the distance in a straight line between the uppermost end of the head, i. e. the cranium, and the convexity of the curve of the tail.

The embryos now under consideration show marked feetal flexures ('Tafel II. Fig. 1 and 2. 5 and 6), with prominent head currature and less marked neck curvature. The flexure at the back of the neck is still less conspicuous in the 30 millim. long embryo (tig. 8). The tail curve in the 26 millim. long embryo (Tafel II, figs. 5 and 6 ) begins almost on a level with the lower edge of the attachment of the umbilical cord, and forms a regular semi-circle; the end of the tail is bent in against the rentral surface. No spiral twists in the direction of the long axis are to be discovered.

The head is divided from the rest of the body by the constriction of the neck; but this constriction, though deep in front. on account of the rentrally directed jaw region, is rery slightly marked at the side and back, though still sufficiently to attract notice. The form of the head is an irregular spheroid with a short and rounded facial part separated from the arched forehead - the cranium, by a slight, transversal furrow lying behind the nasal aperture (figs. 1, 2, 5 and 7 ). This furrow I have named the frontal furrow. The length of the head, measured from the front surface of the upper lip to the curve of the back of the neck, is 11 millim,, thus being between $1 / 3$ and $1 / 2$ of the whole length of the body.

The nasal aperture in the 26 millim. long fretus is a transverse fissure $1^{1 / 2}$ millim. in width, with somewhat raised margins (figs. 3 and 7). On examining it with a magnifying glass, this transverse fissure shows itself to be divided, hy a broad wall lying almost close to the surface, into 2 smaller fissures of which the left one is the shorter. These external "nostrils" are slightly concare below, especially the right one, which is the larger. The raised edges of skin are formed of several small, coherent protuberances, of which those on the right side are the larger. On the 30 millim. long Lagenorhynchus ('mbryo (fig. s) the same thing may be observed, only that there the partition wall lies deeper, while the transrerse fissure is continued a little to the side in the shape of a shallow skin furrow. It is thus unquestionable from the above, that the nostrils in the Delphinidse are double in original construction, and that their fusion is secondary. - The distance between the nasal aperture and the oral fissure is relatively great, riz. 3 millim., an undoubted mark of the Cetacean type.

The cleft of the mouth is $5^{1}: 2$ millim. broad, measured in a straight line between the corners of the month, and turns forwards and downwards (ventro-caudal; see figs. 5-7). If we imagine it continued backwards. it would intersect the concarity above the flexure of the neck, as this continuation would form an acute angle with the long axis of the body. The side parts of the cleft of the mouth have a somewhat sigmoid currature. The large, arched upper lip or upper jaw projects more than the lower jaw. which is separated by a narrow fissure from the ventral surface of the fore part of the body. A hollow is visible on that part of the lower jaw answering to the mentum (fig, 7). Within the slightly open mouth cleft in the 30 millim. long embryo, the tip of the tongue is visible (fig. 8). No indication of any hair formation is apparent on examining the upper jaw with a magnifying glass.

The eye is situated above and to the side of the angle of the moutl. The ocular fissure is 1.5 millim. in length, is open. and forms an irregular oral, bounded by the sunken clefts of the, as yet, mere indications of eyelids. The long axis of the oval of the open eye forms an acute angle with the backward production of the angle of the mouth.

The ear aperture lies abont 3 millim. behind and a little below the angle of the nouth, almost midway between the mouth cleft and the bend of the neck, the continuation of the cleft between the lower jaw and the body being below. The ear aperture forms a short, oblique cleft. 0.5 millim. in length, with almost imperceptibly raised margins. On using a lens of a higher power, the oral or round opening of the auditory passage in the 2 Lagenorhynchus embryos here treated of. is seen to be situated in a little oblong, almost fissure-like carity, which may presumably be considered as homologous with the fossa angularis auris; but no surrounding ridge or other elevation is perceptible.

The external ear of the Cetacea is a subject that has of late receired a considerable amount of attention from investigators. Besides being mentioned by Eschricht (4l), a rudimentary pimna has been described by G. B. Howes, from a Phocena embryo, and even from full-grown Porpoises. Kükenthal (58) has lately described rery exactly the derelopement of the external ear in Whates. haring found in his 25 millim. long Phocoena embryo, that the external carity, the fossa angularis auris, was surrounded by a raised wall with small prominences, of which he could distinguish 6, corresponding 
with what Moldenhauer, His and Gradinigo have pointed out in animals of the class Mammalia and in Man. This caused me to take the matter into renewed consideration, after my manuscript upon the 2 embryos here described had been complesed, two years ago. As the drawings show (Pl. II, figs. 5, 6), I have not been able to substantiate Howes' and Külkenthal's statements. In the 2 Lagenorhynchus embryos $(26$ millin. and 30 millim. long) there is no trace of any indication of protubezances around the auditory orifice. In order to satisfy myself still further as to this circumstance, I examined a Phocæna embryo, 18.5 millim. long, or three quarters the size of that described by Kükenthal; but neither could I here discover the tubercles referred to, surrounding the external auditory orifice. The external ear opening was fissure-like on both sides, and on the right side slightly concave at the back. It lies on a pertectly flat prominence, which cannot lay claim to the name papilla.

The contour of the back is almost straight until it joins the curve of the neck (figs, 2, 5, 6 and 8). On the abdomen, the outline forms a strongly marked convexity in the region of the navel, immediately below which is a 2 millim. long membrum. Below this the outhine is formed by a concavity of the narrow cauda, that is turned towards the abdomen. The outline of the side surfaces is curved, with the greatest curve at the level of the navel (fig. 7).

The small leaf-like pectoral fins, that somewhat resemble embryonal paws (cf. figs. 5- 7 ), are 4 millim. long, 2.5 millim. broad, and $1 \frac{1}{2}$ millim. thick at the root. They spring out from the ventral surface of the body, immediately below the lower jaw, and present a convex outer surface and a concave inner one. On their front margins are some slight indentations (figs. 5 and 6), and the obliquely rising lower edge forms an obtuse angle with the short distal margin. Five thick rays may easily be counted in the pectoral, separated by slight groores, thinner than the rays, on the upper surface. The hindmost ray or digit forms a projecting obtuse angle between the back margin and the distal margin. The second digit from the front is the longest, and extends into the blunt end of the fin. The surfaces of the pectorals are situated almost in the sagittal planes of the hody in such a manner that the outer surface is turned a little upwards or forwards towards the head.

On the surface of the abdomen, the arched part lying round the navel is separated from the rest of the body by a shallow, annular furrow (figs. 3, 5, 6 and 7), and this part differs from the rest of the body in being of a darker colour, owing to the underlying, blood-filled liver, which is here only covered by the membrana reuniens anterior (Rathké). The circular boundary indicates how far the muscle plates have advanced in the formation of the side walls of the body.

Immediately below the navel, at the lower edge of the membrana reuniens, the 2 millim. long tuberculum s. membrum genitale projects; it has a furrow (hypospadi) on the under side, and is thickest at the root. There is a very small, oblong prominence here, at the base of the membrum, which I consider to be the commencement of a fold of skin, which is to form the sheath in which the membrum lies during its further developement, and possibly, also, the first indication of the mamme pudendales. At little outside the base of the genital member, there is, on each side, another slight prominence (see Pl. II, figs. 5, 6 and 7), which is, howerer, scarcely visible to the naked eye. This slightly conical convexity must be kept distinct from the more oblong prominence at the base of the genital member. In the 30 millim. long embryo, the prominence is a little more pointed, but covers a rather smaller area. With regard to its interpretation as a temporary external rudiment of the hind limbs, attention is directed to my remarks below.

On the surface of the abdomen, none but the above-mentioned boundary furrow between the muscle plates of the sides and the membrana reuniens anterior is visible. On the sides and back of the body (figs. 2, 4 and 5 ) in the 26 millim. long embryo, is a furrow, concave in front, separating the back from the flanks (dorsal side-furrow). In the $30 \mathrm{millim}$. long embryo this division between the sides and back is only indicated by a different shade of colour (fig. 8).

In the examination of the specimens here described, I have naturally given full attention to the much debated question of the rudimentary hind limbs of the Cetacea; but I have not been quite convinced that I lave discovered anything, either in the 26 millim. or the 30 millim. long Lagenorhynchus embryo or in the $18.5 \mathrm{millim}$. $10 \mathrm{ng}$ Phocæna embryo that could be interpreted as external rudimentary hind limbs, or rather, perhaps, as rudimentary mamme. I did not, however, feel at all convinced until a short time ago (in January 1894), where I discovered distinct little hind limbs in a 7 millim. long Phocena emlnyo, and rudiments of such in a 17 millim. long Phocoena foetus. After this, I cannot consider otherwise than that the small conical prominences on eacl side of the membrum genitale, described above, are similar rudiments in L. acutus, these rudiments having, in all probability been more distinctly dereloped at an earlier stage.

This explanation has now been most strongly confirmed by examination of serial sections.

The prominence which Kükenthal takes to be the rudimentary remains of hind limbs in the Phocæna embryo (25 millim. long), I cannot regard as corresponding to those liere deccribed, as the relations are somewhat different. I shall return to this subject in the description of the small Phocena embryos.

The tail, cauda, ends i.l a curved cone with the concivity turned towards the ventral surface (Pl. II, figs. 1-3, 5-7); near the pointed end of the tail is an indication of a small swe'ling, which must be explained as the first commencement of the side lobes of the tail-fin. Being now convincer that the rudimentary hind limbs are on the point of disappearing from 
the surface of the body, and that it is only after their disippearance that the rery long tail shows the commencement of the formation of flukes. this may with certainty be taken as an ontogenetic proof of the secondary appearance of tail flukes as a more lately acquired form. How far this fluke formation may be deduced from a primary lateral widening of almost the whole free portion of the tail (Kiikenthal; 58, II Theil, p. 263). as regards Lagenorhynchus acutus, I am not prepared to say.

Recapitulation. In the general impression gained of the 26 and 30 millim. long embryos now before us (figs. 1-8), their mammal-like qualities are those which stand out most conspicuously, their likeness to small embryos from other orders of that class being quite remarkable. On closer consideration, however, it will at once be observed that the special Cetacean type has eren at this stage of decelopement set its peculiar stamp upon these emlnyos. The relatively great distance between the nasal and oral apertures, the external nasal apertures fused into one transrersely-situated cleft (indicating the Odontocete character'). the short neck and the long tail, the absence of external ears and external hind extremities, while the fore extremities are already well dereloped, mark the embryo as Cetacean.

The characters of the class and order are thus, even at this stadium, intermingled, a fact which is interesting to note, as it is usual. in the earlier stages of derelopement, to see only general or plyylogenetic characters.

III. A more adranced condition of derelopement in the Cetacean type is shown in the 45 millim. long embryo (Pl. II. figs. 9. 10 and 11). Among the futal flexures, that of the neck is almost obliterated, while that of the crown of the head, the principal cephalic flexure, and that of the tail are still distinct. The snout portion of the liead forms a right angle with the long axis of the body. and the constriction of the neck is distinct only in front, there being but a slight indication of it at the sides.

The round head with short, pointed nose, the obliquely-situated, closed eye fissures, the inward-turned pectoral fins beginning to assume a semilmar shape, and the still conical tail, where the first trace of the tail-fin at the point, gives it a bud-like appearance, are the characteristic features of this nearly 5 centim. long embryo, which has attained to about $1 / 20$ of the size of the newly-born animal. The umbilical cord is attached beyond the middle of the borly.

With regard to the details concerning this embryo, the following is to be noticed: -

The liead has an almost spherical cranium and a short, conical facial region. Its height from the neck to the crown of the head measures about $1 / t$ of the length of the body, its natural length. i. e. from the end of the nose to the bend of the back of the neck, measuring about $1 / 3$ of the length of the body. The diameter from the mouth to the back of the neck forms a right angle with the long axis of the body, and measures 18 millim. The slightly curved external nasal aperture is a $t$ millim. broad, transrerse fissure, and may be said to form the boundary between the snout and the forehead which arches upwards and disappears into the round cranium. The external nasal fissure has rather full lips, and shows an indentation in the middle: the right side region is a little larger than the left. - The facial region or snout seen in profile, resembles a short, curved bird's beak fig. 10). The upper jaw is arched, the lower more straightly projecting and forming, with its lower surface. an obtuse angle with the ventral surface of the body. The 6.5 millim. broad mouth fissure measures 4.5 millim. in length from the point of the jaws to the angle of the mouth, and runs straight in perpendicularly to the long axis of the body. On each side of the upper lip, a little above the month fissure is a slightly raised line with from 6 to 8 wart-like protuberances. which are indications of the incipient foetal hairs. The edge of the lower jaw is narrow in front, broader beyond, and inclined a little downwards; the edge of the upper jaw is also narrow in front, and inclined a little upwards beyond. The edges of both lips form a conical point in front.

The $1^{1 /}+$ millin. long eye cleft is situater at a distance of $t$ millim. from the mouth fissure. with which it forms an acute angle. if the montl cleft be imagined produced as far as to the eye. In a front aspect, the eye region forms a slight convexity. A little below and behind the eye, the external ear appears in the shape of a spot somewhat different in colour from the rest of the skin, and whose greyish yellow hue cannot easily be distingnished without the aid of a magnifying-glass: on the right side it forms a small, very slightly projecting prominence.

The depression between the crown of the head and the back of the neck, which was rery distinct in the previous stadium, is here effaced.

The contour of the back is almost a straight line down to the tail, which has only a slight, rentrad curre, and points downwards and to the side (Pl. II. figs. 9-11). The rentral surface is not nearly so arched as in the 26 millim. long embryo, and the side surfaces from the head down towards the tail, present only a slight convexity (fig. 11). The trumk is thickest between the navel and the anterior extremities. Beyond the navel. the cylindrical body rapidly decreases in thickness.

The fore-extremitics have already, to a great extent. assumed the shape of those of the Delphinidx. They lie witl their pointed lobes inclined inwards towards the median line. Neasured in a straight line along their front edge, i. e. 
cephalic margin, they are 8 millin. in length, the caudal margin measuring 5.5 millim. Springing out immediately below the angle between the lower jaw and the ventral surface of the body, they first take a directly ventral direction, and slightly medial, and then the distal, triangular part inclines in a medial and caudal direction. The cephalic margin forms a convex curve with a slight concarity on the transition between the antibrachium and the manus; the caudal margin is broken into a short, concave, proximal part (fig. 10), which forms an obtuse angle with the slightly longer and concave, distal part. The cephalic and caudal margins converge distally so as to form an acute angle. The distal part, or manus of the pectorals, is longer than the proximal part, which corresponds to the fore and upper arm. Four decided rays, or digits can be distinguished, the longest of which lies in the cephalic margin.

In the middle of the arched surface of the abdomen is seen a distinct raphé running from the navel forwards towards the lower jaw, and backwards towards the tail. Surrounding the insertion of the navel is an oval field, more pointed in frout, and bounded on each side by a slight prominence. This oval umbilical field denotes that part of the wall of the abdomen which is covered by the membrana reuniens anterior, while the outer boundary indicates the medially growing side-plates. If we compare this embryo with the one immediately before it, we see here a further advance of the side plates. Below the narel, the boundaries of the umbilical field are covfluent at the outer genitalia (Pl. II, fig. 11).

At this stage the genital aperture is distinctly separated from the anus. The membrum genitale is large and projecting; and bends towards the tail like a hook. Farthest in on the under side, it is hollowed out, and the genital opening lies like a carity at its base. Immediately below it, the anus is observalule in the form of a small dot-like opening.

On both sides of the genital aperture, a somewhat long, whitish, and slightly raised region can be distinctly seen, denoting the rudiments of the mammæ pudendales (Pl. II, fig. 11).

The almost cylindrical, conical cauda shows signs of side compression, as its ventral and dorsal sides present a sharp edge. Towards the end, the side surfaces become prominent, forming the commencement of the side lobes of the tail fin (Pl. II, fig. 11). Neither in the preceding stadium nor in this one have $\mathrm{I}$ found anything to indicate that "nearly the whole of the free tail becomes broader by lateral folds of skin", as Kükenthal states (cf. Lit. No. 58, II Theil. pag. 263). There is still a distinct bend in the tail, although its distal part is turned more in the direction of the long axis of the body. It is, howerer, begimning to incline towards the side (right).

The umbilical cord is 18 millim. long, and 4 millim. broad at the place of insertion. It increases a little in thickness immediately outside the insertion, and then gradually decreases towards the periphery.

Although the colour (fig. 10) in this hardened specimen is a uniform grey, a skin-colouring can clearly be seen in the neck region. This at first appears like a "neck-band", extending sideways towards the eye, and backwards in the median line of the hack. It is not, however, until later that this colouring exhibits its characteristic distribution.

IV. When the embryo, measured in a straight line from the crown of the head to the extended end of the tail, attains a length of from 7 to about 10 centim., several family characters already begin to appear in addition to the foetal Cetacean ones. While the head gradually takes a more foreward direction, so that the nasal aperture becomes the most adranced point, instead of the crown of the head as in eartier stages, the commencement of the dorsal fin is also visible, the little tail lobes become more distinct, and the pectoral fins assume more and more their peculiar, pointed, elegant shape ('liaf. II, figs. 12-14).

Of the foctal curves in the smallest $\left(7+\right.$ millim. $\left.{ }^{1}\right)$ long) of the 6 foetuses of this stadiun at our disposal, the head flexion is still apparent; in the longer embryos the facial region has become a little more straightened out (cf. fig. 12). The nose is longer and more pointed thian in the t5 millim. long embryo. In the 74 millim. long specimen, the production of the line of the mouth cleft forms a somewhat obtuse angle with the long axis of the body; in the slightly longer embryo this angle, which is open to the surface of the abdomen, becomes more obtuse (figs. 12, 13). At the side of the snout region of the larger embryos, a slight indication of a break may be detected, a characteristic mark of the Linnsean Delphinus genus. On the upper lip there is a distinct raised line with from 5 to 7 dot-like prominences denoting the commencenent of the fortal hairs (Pl. II, fig. 12). The mouth cleft extends so far backirards, that the frontal plane through the angle of the mouth will intersect the nasal apertures. The obliquely-set eye cleft forms an acute angle with the mouth cleft, if the latter be imagined produced backwards until it intersects the hind edge of the eye clett. The region of the eye itself forms a hemispherical protuberance at the sides.

The nasal orifice. in the about 90 millim. long embryo. forms a slight concavity behind, with its edges a little raised. In the smaller embryos there is a small prominence in the middle of the nasal cleft, most marked on the hind edge, but this becomes more obliterated in the larger enbryos. 
Below and behind the cleft of the eye is found the excessively small ear aperture, which may be recognised as a small cavity with a tiny lole in it.

The under surface of the lower jaw makes a more and inore obtuse angle with the surface of the abdomen, as the embryo increases in size which is an indieation that the facial region, together with the jaw and throat increase relatively more.

The pectoral fins begin to assume more their characteristic form. The convex ventral margin and the projecting angle on the dorsal margin are also peculiar. The digit-rays show distinetly through.

The rudimentary dorsal fin imparts to the formerly straight outline of the back a convexity which is opposite to the umbilicus. Though searcely projecting in the 73 and 78 millim. long embryos, it measures from 1 to 2 millim. in the embryos over 90 millim. in length. There is also visible a little comb-like eleration in the medial line, extending backwards right on to the tail. - The insertion of the umbilical cord lies near the middle of the body. In the embryo that is over 90 millim. in length, there is still a broad furrow in front and belind this insertion, the boundary between the rapidly approximating muscle-plates of the sides of the hody.

The shaply curved membrum genitale conceals the entrance to the urogenital canal. At the base of the membrm indications of the mammx pudendales are observalule in two small prominences, in each of which, by the aid of a magnifying glass. a minute hole is seen. The rery small anal opening is situated not far behind the genitalia (fig. It).

The tail has lost much of its conico-cylindrical shape, and has become flattened at the sides, the dorso-rentral dianeter having. relatively, increased considerably. The lobes of the tail are large, triangular pieces. The whole eauda has straightener itself ont, still more than in the earlier stages, in the direction of the long axis of the body, with a slight inclination to the right.

A considerable change of colour may be noticerl in all the fatuses of this stadium. In the region of the back of the neck, there is a lroar. dark band of colour. - the "neck-band", extending down to the region behind the eyes. In front of this dark band. the slin of the head is of a very slightly darker shade, while behind it, on the back as far as the dorsal fin, a darker skin colom is clearly visible (cf. Pl. II. fig. 12). This blackish grey colouring of the skin may also be traced some way down over the sides. The dark rariation in colour is inconspicuous on the smaller embryos, stronger and more distinct on the larger ones. No change, however. has taken place in the eye region, the snout, the ventral surface or the tail, in those emlryos that are less than 10 centim. in length. The natural skin colour of embryos just taken from the uterus is always pink. with a little grey in it, the pigment or dark skin-colour appearing in the shape of tinges of colour from grey to blue-black. This pink ground-colour with the greyish tinge in it is owing to the quantity of blood in and suculence of the tissues, while the darker colour is caused, as is well known, by the pigment deposit in the skin. By hardening in alcohol, the reddish colour is changed to white or greyish red. while the dark colour remains almost unchanged, always presupposing that the embryo has been preserved in a fresh condition and not allowed to lic for some time, so that carlaveric changes have set in.

V. The ymerie characters begin to appear in frotuses of Lagenorlignchus acutus, Gray, that are from 10 to 20 centim. in length (Pl. III. figs. 1 and 2). The characteristic features of fortuses of this size (which is from $1 / 3$ to $1 / 5$ of the size of the full-grown furtus) may be shortly recapitulated as follows: -

The snout points almost straight forwards, so that the foremost part of the liead is formed by the region extending from the external nasal apertures to the apex of the upper jaw; the pectoral fins lhave thescuilunar shape peculiar to Dolphins, and, while the fortal tailflexion has disappeared, the candal segment of the horly begins to assume a ventro-lateral curve; to these is added a dorsal fin sereral millinetres in leight, while, botween the large triangular lobes of the tail-fin, there is a little cleft, and their posterior edges take the shape of an S. Sexual difference is here rery distinct.

It may lo remarked. with regard to the relation between the body and its various divisions, that the head amounts to about $1 / .+$ the length of the body, the pectorals to from $1 / 4,7$ to $1 / 5,4$, whle the navel insertion lies at about the middle of the ventral surface of the body; though fregiently a trifte further back.

The liend. In proportion as the nose takes a more forward and mpward direction. the angle between the lower jaw and the surfice of the abdomen disappears (fig. 2). The arehed uppor jaw becomes more pointed anteriorly, and the slight groove beginning a little alove the angle of the mouth, and ascenting obliquely on the nose towards the median line. beenmes more prominent. forming the break peculiar to the Delphinus family; viz. the "beak". On the upper lip may be comnted the commencement of ${ }^{\prime} ;$ or $^{\circ} T$ hairs; the upper lip is in the form of a gentie sigmoid curve, which produces a convexity downwards, somewlat behind the apex. The lower lip is a little everter, the retreating upper lip overhanging it at the angle of the mouth (Pl. III, fig. 2). 
The opening of the nose on the top of the head, lies in the frontal plane between the angle of the month and the eye fissure; it has a tendency to become semilunar, with the concavity to the back. The full front margin encroaches so to speak, at its corners, on the somewhat full hind margin, which bears in the middle a slightly raised spot of colour.

The previously very oblique eye fissure gradually assumes a horizontal position, i. e. parallel with the long axis of the body. The eye region now begins to be less prominent. The ear aperture which is very indistinct and difficult to find, lies from 4 to 6 millim. behind, and a little below the eye cleft.

The upper contour of the head abore the nose describes a sharp, convex curve at the back of the head, before it joins the almost straight line of the back. The occipital region is thus the most convex part. No neck segment is now distinguishable.

The greatest thickness of the trunk is immediately in front of the insertion of the umbilical cord and the dorsal fin, whence it tapers backwards like a narrow cone slightly compressed at the sides. The contour of the back is somewhat straighter in front of the dorsal tin (still with a slight concavity at the neck in the younger foctus), and behind it, is convex to the very end of the tail, concerning which further remarks will be found below. In the contour of the abdomen, there is a slight concarity between the pectorals, which gradually decreases in the larger embryos, until, in the umbilical region, a slight convexity is formed, while the lateral curve of the tail generally begins in the region behind the anus.

The pectoral fins are situated somewhat behind the front fourth part of the body. As before stated, they amount to from $1 / 4.5$ to $1 / 5$.; of the length of the body. Their convex ventral margin has a slight depression in the region of the (arpus. The dorsal margin is sharp, and forms, in its larger distal portion, a concave half-moon (fig. 2), followed by a triangular protuberance, which, in its turn, merges into a straight or concave, less sharp, proximal portion. As regards the position of the pectorals, they lie more or less against the ventral surface, or project, so that their dorsal surface is parallel with the side surface of the body.

The triangular dorsal fin forms, in the smaller embryos (fig. 1), a semilumar protuberance, from 3 to 5 millim. in height, with no sharp boundary-line defining its base from the surface of the back. In the larger fortus (fig. 2) where the dorsal fin is from 8 to 10 millim. high, its base limit becomes more clearly defined; the highest point of the fin, which was formerly rounded. is now more pointed, the gently ascending front margin is distinguished by its shape from the slightly concare, and much more abruptly descending hind margin, the dorsal fin, as a whole, thus approximating more to the form characteristic of the genus (fig. 2). The foetal character is, however, still prominent in its relative position, which is almost opposite to the insertion of the umbilical cord, though in such a manner that the point of the dorsal fin lies rather behind a transversal plane through the former. The posterior margin of the dorsal fin is continued as a low keel for a short distance backwards down the median line of the back.

In the median line of the abdominal surface there is a raphé in the form of a fine, whitish line; in the smaller embryos, around the insertion of the umbilical cord, there is often visible a field, pointed at both ends, and separated from the side regions by a conspicuous groove. recalling the conditions in the earlier stages.

The genitalia externa at this stage, are of consiclerable interest. Ilost of the frotuses were females, only a small number being males. viz. 16 females and 8 males.

The entrance to the female genital aperture is for the most part covered by the greatly dereloped clitoris. which forms a caludilly-directed hook with a hroad hase. Around this and the sexual aperture, which is an open, oval cavity, the slin is pufted up into incipient labia major:. Immediately to the side of the sexual fissure, and separated from it only by a shillow furrow, the mammic pudendales cone into view like little prominences, one on either side, with a small fissure-like depression on the top of cach. Immediately behind the sexual aperture, the anus may be detected, looking like a small puncturc-like opening.

In the male fortuses the external genitalia are in the form of an anteriorly tapering elevation. The process-like penis. from 3 to 4 millin. in length, points in a forward direction, and protrules from a cylindrical skin sheatl (preputium) which posteriorly merges gradually into the skin. In the median line there is a raphe up to the anus. In the full part lying behind the preputium, two suall depressions may be detected. lying close to one another, indications of the rudimentary mimmie misculina.

The tail or "postanal" portion of the trunk is, at this stadium, compressed at the sides, and rather high, forming on the dorsal and rentral surfices a sharp ridge, from the distal part of which project the triangular side-lobes, forming a somewhat convex dorsal surface, and a slightly concave rentral surface. In the larger foetuses the hind margin has a sigmoid curvature, with a cleft in the middle, the side points still being rounded. The tail, as already stated, inclines, in the larger furtus (fig. 2) to one sidc. either the right or the left. This side inclination is more dereloped in later foxtal existence, so that in the full-grown futus. the tail is always found pressed up against one side, thus occupying a smaller space in the uterus.

The colouring of the skin. The distribution of colour orer the skin of furtuses in this stadium is it subject of extreme interest. The darkly coloured "neck-band" mentioned in the previous stadim, is, in fietuses of from 10 to 20 
centim. in length. inrariably of an almost black hue, and is accompanied by one or more dark bands on the head, rumning parallel to one another (Pl. III. fig. 1). This neck-band runs straight down in front of the eyes. forming a curre orer the back of the head with the concarity to the front (in the 110 millim. long foutus. it forms an anteriorly open angle). In front of this blne-black band, the general colour of the head is lightel. The region surrounding the nasal aperture is light, while again, that lying a little in front of it is darker. the anterior boundary of the dark colour being a little abore the snout portion (Fig. 2). There is, howerer; a diffuse colonring along the median line, which spreads to the front and includes the apex of the upper jaw. which is somewhat darker. Three zones, in all, are distinguishable on the head. The colour of the head in the smaller foetuses is more like a thin shade, while in the larger ones (e.g. 170 millim.) it is darker, and advances from the side towards the middle. In this way the present species (Is. acutus) exhibits at a certain stage a colourless part orer the snout, which recalls L. albirostris. Towards the back the dark colouring passes into a continuons whole, so that the back and ruper part of the sides are dark, the intensity of the colour diminishing posteriorly. The darkest part is that near the "neck-band" and round the eyes. while the eye region itself" is colourless (fig. 2). On the lower" eyelid, however. jnst below the eye fissure. a dark spot is risible. which increases in size with the growth of the embryo. From the lower part of the dark ring surromding the eye, a more thinly coloured band stretches backwards to the pectoral fin, (Fig. 2), which exhibits a widely-spread, lighter colouring on its outer side. The part round the dorsal fin is lighter, while the lower part of the fin itself is a little darker, the point again being light. A narrow dark line runs behind the dorsal fin along the median line, while the adjacent regions are lighter. On the side surfaces the dark colour spreads right back to the tail and the tail-lobes, at first only as a faint tinge, but becoming more pronounced as the embryo increases in length. The dark sharle of colour on the sides spreads down until it is on a level with the eye, and, behind the narel, still lower. There is, however. on the 170 millim. long foetus, an oblong patch of white on each side of the hind part of 'the body, namely; that part extending hackwarts from the frontal plane through the navel, - a "dorso-lateral" band, recalling the light band-like patsh characteristic of the Lagenorhynchus acutus. There is also, in the somewhat older foetuses, an oval colonrless region situated above the pectorals.

The tail-lobes. on both their upper and under surfaces, have hegun to acquire a light grey tinge.

The surface of the abdomen is without colouring nntil beyond the anus. although a tinge of grey is discernible on the preputium penis.

On a microscopical examination of skin sections, the pigment granules are found deposited in the region around the nucleus.

VI. When the futus has attained to half its full size, i. e. from 40 to 50 centim. in length, most of the external specific characters have already made their appear:mce. A 455 millim. long futus, which' was at our disposal, had, it is true. a somewhat defective epidermis, but nevertheless possessed characteristic marks.

'The frutal flexion of the facial region of the head is still apparent, but only slightly marked; the arched forehead and eranium, and the rounded snout show the fortal character.

The dolphin's "beak" is rery much dereloped, but still round and stumpy. Six fortal hairs may be counted on the npper lip. The nasal orifice is a transverse fissure with full lips. lying a little in front of the frontal plane of the eye. The hearl is $1 / 4$ of the length of the borly. 'The pectorals (71 millin. long) amount to $1 / 6.4$ of the length of the body. The insertion of the umbilical cord lies in front of the middle of the body, and directly below the dorsal fin. This fin, which is 58 millim. high, amounts to nearly $1 / 12$ of the length of the body. The postanal portion is very much compresser and high. It forms, anteriorly to the beginning of the tail-lobes, a narrow ridge, which sinks into a low keel on the upper and mimler surfaces of the tail-tin itself. This fin, 102 millim. broald (about $1 / 5$ of the lengtlo of the body), has a deep groove in the middle, and is cut out behind in the shape peculiar to the genus.

The extent of the very dark colour was somewhat difficult to determine in the specimen examined, on account of its dofective epidermis. It can. lowerer. be stated that ahnost the entire head is of an even blue-black colour, while the beak is light grey. The region round the eye has also become black, as also the entire pectorals, with the exception of the ligliter grey streak from the eye to the axilla. The darker colour on the sides has spread farther down than before, while the peculiar side patch is more limited. The dark colour on the tail has spread right down to the under side, and ceases a little behind the anus.

VII. Cnder the headings "ahnost full-grow" and "full-grown", I have classed fortuses of from 75 to 95 centin. in length. Four such were examined, of which one 745 millin. one 825 millim., and me 842 millim. in length, are considered as "almost full-grown". and one 950 nillim. long, as al "full-grown" furtus. The 842 millim. long faitus is depicted in lig. 1 in the letter-pres.

According to the general rule, the size of a neir-born Toothed Whale should be $1 / 3$ of the mother's length. As the male in this species is ligger than the female, and their greatest length, according to Rasch (66) is 2.630 male, and 
2.310 fem. (measured in a straight line from the apex of the lower jaw to the extreme point of the tail fin) the 95 centim. long fœetus might in that case be regarded as quite full-grown, for its length amounts to more than $1 / 3$ of that of an ordinarily large female White-side. It may probably, however, be assumed that the size of a newly-born young one of this species, as of the Phocina, is more than $1 / 3$ the length of the mother animal. If the 95 centim. length be taken as the basis of calculation, the size of the new-born animal is $\% / 5$ that of the mother. and we may perhaps add, that the female fotuses are somewhat smaller than the males, just as the full-grown males are larger than the full-grown females. There are, of course, also variations in the size of new-born animals of this species, as there are of other species of Mammals.

As the 842 millim. long foetus was in the best state of preservation, and drawings were therefore made of it, it will be the subject of the following description.

Proportions. The head is ${ }^{1} t^{1} \%$ of the length of the body, the pectoral fins $1 / 5$ (from $1 / 4.9$ to $1 / 5.4$ in the other fortuses), the dorsal fin between $1 / 10$ and $1 / 11$ of the length of the body.

The head. The front part of the facial region, "the beak", is well developed, but reveals its fotal age by the rounded shape; there are 6 or 7 foetal hairs to be counted on each side above the mouth fissure. The 112 millim. long upper lip is straight but for a slight sigmoid curvature, a rather downward-tending convexity in the foremost part. In front, at the median line, the upper lip describes a little descending curve: answering to a depression in the apex of the lower jaw. The furrow between the "beak" and the upper part of the face is deepest in front, on both sides of the median line. The 95 centim. long foxtus also slows here; in the middle, a little loreak or larger concavity. so that the upper contour of the head which forms a gentle convexity from the crown downwards over the front, here becomes a concavity marking the boundary between the "beak" and the facial region abore it, and then describes a convex curre to the apex of the upper jaw. The shape of the lower lip is sigmoid, with the greatest concarity above in the middle (cf. fig $1, p, 21$ ). Its foremost end projects a little beyond the apex of the upper jaw. Within the lip, between it and the dental series, there is a long keel, which becomes broader until it loses itself at the back. In the slightly open mouth can be seen the anteriorly free tongue with its fringed edge. - The eye fissure $\left(12^{1} / 2\right.$ nillim. long) lies a little above $(12$ millim.) the angle of the mouth, and about 22 millim. behind it. There has been no relative change in the level of the eye region. - The ear aperture. about 1/2 millim. in diameter and at a distance of 14 millin. from the hinder angle of the eye, lies a little lower than the cleft of the eye, but above the continuation of the mouth cleft backwards. - The nasal aperture now presents its peculiar semilunar form. with the convexity turned forwards. The frontal plane through the back of the blow-holes almost intersects the anterior angle of the eye.

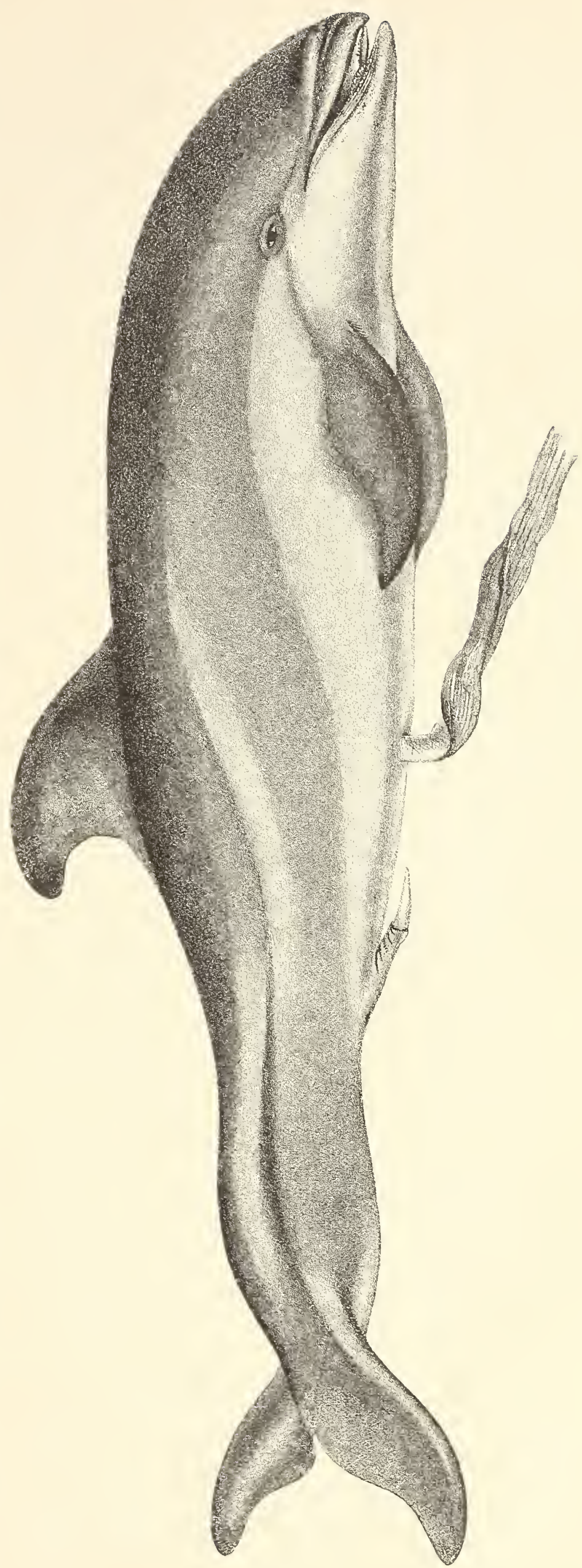

Fig. 1.

Lagenorhynchus acutus, Gray. Futus $8+2$ millim. long. 
The body has the elegant spindle shape characteristic of the species, with the greatest thickness in front of the navel, between the dorsal fin and the pectorals. In the foetuses from 75 to 84 centim. in length, a slight sinking of the outline of the body behind the head is apparent, but this may possibly be due to the preserving process. It does not appear in the 95 centim. long fuetus. The pectoral fins, which are situated very low down, at the junction of the thanks with the abdominal surface. are 155 millim. long in the 84 centim. long fuetus, and antount to ${ }^{1}{ }^{5}$.t of the length of the body. Their convex rentral margin and concave dorsal margin with the angular convexity in its inmost third part, are of the same character as in the full-grown animal.

The $u \mathrm{mbilicus}$ is mnder the middle of the dorsal fin. 'The penis is not withdrawn into any fold of skin, but lies with the preputium right out. Half way between the glans and the anus, at the base of the prominence of the genital region. there are 2 clefts, each about 2 millim. in lengtl, lying side by side, which are the rudimentary mammie.

The postanal portion is very much compressed and high, with a pronounced dorsal and ventrat comb in the part lying immediately in front of the tail. The tail is deeply cleft, and the highly developed tail-lobes stretch out their points far beyond the cleft (tig. 2, p. 22).

Distribution of colour. The black or blue-black colour is distributed over the whole of the dorsal surface of the body. and, in the tail region. over the rentral surface also, extending forwards almost up to the anus: the pectorals are also black. The surface of the abdomen, on the other hand, is light or whitish. The upper jaw is also of a dark colour, with the exception of the lighter margin of the upper lip. The lower jaw, like the abdominal surface, is whitish. Three belts of colour may thus le distinguished on the body, viz. the almost black dorsal colour, the greyish colour of the sides, and the whitish colour of the abdomen. The greyish zone begins on the upper jaw above the eyes, and

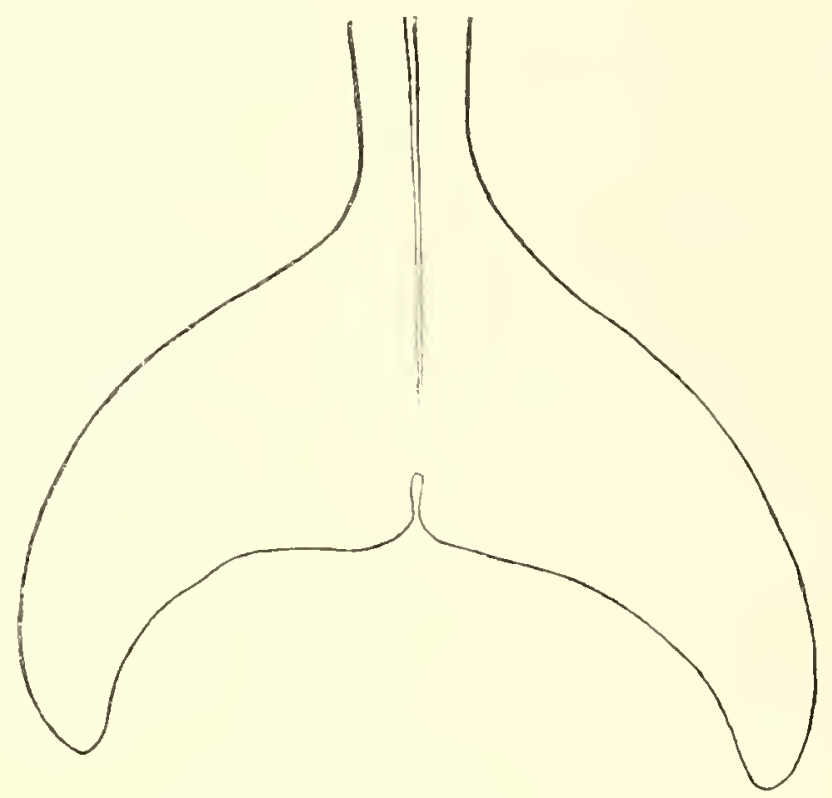

Fig 2.

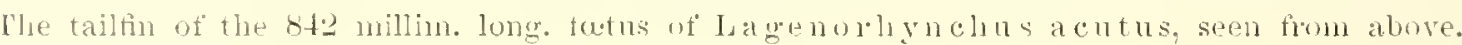

includes the greater pat of the side surfaces right out to the tail fin, (with a rather lighter tinge in the neck and chest. regiom) descending farthest at the navel and genitalia. The boundary above is a convex curve lumning to the back of the anns. The dorsolateral patch rharacteristic of the species "acutus", which commences beneath the dorsal fin, is now alleady divided into one anterior. long, oral, lighter. lower part, and one posterior. band-like part. of a greyish shade, ruming forwards like a narrow band by the side of the white. - Among other peculiarities of colouring maly be noticen a back streak. uniting the dark part of the upper lip with the darkly coloured eye region, thus imparting the appenrance of suectacles, and a blackish-grey streak from the eye region to the pectorals (Fig. 1 in the letterpress, p. 21).

General remarks. Although we camot. unfortunately, draw any decided conclusions from the deformed 8 millim. long embryo as regards the outward form. yet the relatively enormous length of the tail seems to be a characteristic feature of quite small embryos of the Cetacea. This must be put down as a peculiarity which must be taken into account if an opinion is to be formed of the phylogeny of these animals.

The little embryos from $2 \frac{1}{2}$ to 3 centim. in length have alreatly a few of the characters of the Cetacean type mingled with the ordinary mammal-like features. and the Odontocete type is recognisable before the embryo has attainerl to $1 / 10$ of the size of the new-born animal. When the fortus las attained to $1 / 5$ of its full length, the generic characters begin to appear: and when it is half-grown as regards its length, the specific characters already assert themselves. 
Thus the latter half of the embryonal time seems to be employed in developing the specific characters, while drobably, in reality, all the Cetacean characters and the imner organs standing in corelation with them, continue steadily to be developed and perfected, so as to ensure the air-breathing, warm-blooded young mammal an independent existence in the cold, rough element.

The course of developement shown by the above-described copious embryonic material, from the embryo of $2^{1} / 2$ centim.'s length to the full-grown fotus, makes the deduction of a few general conclusions justifiable. As soon as the ordinary embryonal mammal-form is attained, the characters of the order and of the sub-order appear, and assert themselres. These are closely followed by those of the family, genus and species. What is remarkable in this is, that distinctive generic and specific marks make so early an appearance, or. in other words, that the embryo's developement aims directly at the special genus and species. The embryo seeks, by the most direct way, if I may use the expression, to attain to the likeness of its parents, or, in other words. to the specific form. This also shows how cautiously one must advance if direct phylogenic conclusions are to be drawn from embryological phenomena. 

II.

2.

GUSTAV GULDBERG

ON THE DEVELOPEMENT

OF

LAGENORHYNCHUS ALBIROSTRIS, GRAY. 



\section{Lagenorhynchus albirostris. Gray.}

S

ince Gray's and Brightwell's descriptions of this species of Dolphin, about 50 years ago, acquaintance with its external appearance and skeleton has been considerably extended. There exist many representations of the full-grown animal, which, howerer, are remarkable for their disagreement in point of colour, an evidence of the numerous variations in this species, in that respect. The full-grown male, according to P. J. ran Beneden, attains to a length of 3 metres, while the females are somewhat smaller. After. James Grieg's measurements, the largest female that was observed, in the Whale-take on Bildöen near Bergen in 1S87, was 2.74 metres long, while the largest male measured 2.98 metres in length.

This species of Dolphin occurs not infrequently on both the north and south coasts of Norway. Subfossil remains of it have been found (Guldberg 108), and, during the last decade, "schools" of "Ihite-beaks" hare been taken on the west coast of Norway (cf. Grieg 117).

Foetuses of this species have been described by Lütken and James Grieg. Sven Nilsson (S9) mentions a 1\% feet long fortus from a female which had run on to a sand-bank between Skanör and Hammar (Sreden).

Professor Lütken (116) describes 2 fotuses of Lagenorhynchus albilostris, a male 790 millim. and a female too millim. in length, and subjoins a table of measurements. These foetuses possess most of the specific characters, and must be placed in the class which I have designated as "almost full-grown".

James Grieg gires the exact measurements of the three albirostris foetuses which hare been at my disposal for the present inrestigation. The largest measures 1130 millim., the two others 765 and 720 millim. respectirely.

The lar"gest foetnses, 1130 millim., I agree with J. Grieg in classing as "full-grown". As the largest female measmed was $2.7 \pm 0$ metres (J. Grieg) it will not come far short of the truth if we take the length of the newly-born animal to $h e s / r$ of that of the mother. It would undeniably hare been of great interest, if the female from which the embryo was taken liad been measured.

The examination of these large fotuses is of interest, inasmuch as they amplitly and substantiate the results furnished by L. acutus, riz. that the specific characters appear distinctly, beginning by degrees to assume their definite form, as soon as the foetus has attained to half the size of the newly-born animal.

I. The smallest of the abore foetuses which I cxamined was a female, and measured 720 millim. in length Its dimimution in length, after haring lain in spirit for about four years, proved to be exceedingly slight, riz. less than 10 millim. In comparing it with the furtuses of Lagenorhynchus acutus, it must be classified as "almost full-grown.." as it measures about $2 / 3$ of the length of the full-grown young. 'T'he length of the head is contained hardly $41 / 2$ times in that of the body, the pectoral fins amount to more than $1 / 41 / .(1 / 4.6)$ of the length of the body $(1 / 6$ in the full-gromn animal), the height of the dorsal tin is more than $1 / 11\left({ }^{1 / 11.4}\right)$, and the width of the tail fin $1 / 4$ of the length of the body.

The head is of a rounded, conical form, with a distinctly marked-off "beak", upon the front end of which may be counted 4 foetal hairs. The upper lip describes only an extremely slight sigmoid curve, with a convexity in front. The edge of the lower hip forms a downwardurnerl concarity with a keel within. In the jaw, the teeth are about to break through. The anteriorly tree tongue has a crenulated erlge. The deep groore which separates the beak from the rest of the facial part is interrupted at the median line, but is deepest at the sides, becoming shallower and finally disappearing in front of the angle of the mouth. 'The region of the eye is rery prominent (the reverse of that in L. acutus) and is situated a little above. and about 2 centim. behind the angle of the moutl. At a similar distance behind, and a little lower than the eye fissure lies the little ear aperture, in appearance like a whitish dot, of the size of a pin's head. The nasal 
orifice is a fissure of the usual anteriorly concare form with raised edges, of which the front one is the higher. The transverse plane through the blow-holes passes through the eye region a little in front of the anterior angle.

The shape of the trunk is elegant on the whole, and not clumsy. The contour of the back from the crown of the head sinks slightly in the region above the pectorals. The greatest circumference is between the pectorals and the narel, beyond which the body gradually tapers at the sides. The pectoral fins are situated, as in L. acutus, rather far down towards the rentral surface. They are rather broad, and not nearly so pointed as in D. acutus, a fact which Liitken (116) also remarks. The supcrior dorsal margin forms an obtuse-angled convexity, which passes into a distal concare portion. The insertion of the umbilical cord is rather more in front of the middle of the body, being farther forward than the dorsal fin. From the navel to the genitalia externa (vulva) there is a groove in the hinder part. The clitoris and preputium lie on the same level as the labia majora. The mamme pudendales form two small prominences with a fissure in which lies the papilla. The greater part of the dorsal fin lies beyond the middle of the body (posteriorly). As in the full-grown animal, it lias a long, backward-bending point. Its basal portion extends backwards for some distance as a keel. The post-anal segment amounts to rather less than $1 / 3$ of the length of the body, and appears most compressed just in front of the tail-fin, as in the full-grown animal. A considerable dorsal and rentral keel is developed, which is most elevated midway between the anus and the cleft of the tail-fin, disappearing on the tail-fin itself. The latter is deeply cleft, in the slape characteristic of the species.

The distribution of colour in this embryc, as in corresponding embryos of L. acutus, is already so strongly marked, that several of the specific character's disclose themselves. The bluish grey colour, often tinged with brown, extends from the facial part immediately abore the "beak", backwards orer the head and hack, spreading orer the greater part of the post-anal part of the body. On the head, the dark skin colour extends helow the eye, its boundary being an oblique line from the angle of the mouth downwards and backwards to the shoulder-joint. The pectorals are wholly dark, as in L. acutus. The eye region is somewhat lighter, while a darker band runs from the "beak-furrow" to the eye region, where it becomes paler. On the sides of the body, betwecn the pectorals and the genital region, the colour is a lighter, yellowish grey. There is also a rather lighter shade of colouring over the dorsal part of the post-anal section of the body, as also orer the back of the head and neck on each side of the median linc, from the neighbourhood of the blow-holes backwards to about midway between them and the dorsal fin. The lighter, umpigmented part includes the "beak", the lower jaw. and the whole of the chest and rentral surface to beyond the anus, whence it extends like a light border along the ventral keel, to the inferior surface of the tail-fin.

The somewhat larger 760 millim. long fatus agrees in every respect with the above. It had 4 fotal laairs on each side of the upper jaw.

II. The full-grown fotus (male, 1130 millim. long) presents no striking differences from the embryo just describerl, except that the cliaracters have gained a still greater similarity to those of the more full-grown specimen. The lengtl of the head is contained from $4^{1 / 2}$ to 5 times in that of the body, the pectorals amount to $1 / 5 \%$ of the total length, the insertion of the navel string is considerably in front of the middle of the body, while the dorsal fin is rather behind than exactly orer the middle (in the full-grown animal it is more in front of the middle).

'The "beak" in this specimen, besides being bounded at the sides by a deep furrow (the beak-furrow, sulcus rostralis) is also separated in front on the median line from the pre-nasal facial part lying above it. The relative position of the nasal aperture is about the same as before described. The eye region is less prominent, and the minute ear aperture appears as a white spot of the size of a pin's head. The distal end of the broad pectoral is more rounded, and upon the concaro-convex dorsal maroin, the convexity includes the proximal half (in D. acutus the proximal 1/4). The penis is about to be drawn into the fold of skin, and is already partly hidden. Immediately in front of the anus lie the two small folds which indicate the rudimentary mammæ masculinx; but they lie nearer to the anus than is the case in D. acutus. The post-anal segment, which is less than $1 / 3$ of the total length, has, in its middle, rertical portion a high dorsal and ventral keel. 'This part of the body is 14 centim. high.

Several teeth are visible in the carity of the moutl, coming through on the side portions of the jaws, while in front there is no trace of them. The teeth feel soft to the touch. The tongue is free in front, and fringed at the edges. On each side of the upper lip were found 4 fotal hairs (cf. James Grieg 117, p. 16). Tiitten found on the largest of the embryos described by him. 3 hairs on the one side and 4 on the other, while the smallest had 5 on each side. Cunningham and C'larke have, as is well known. recorded $t$ bristles on each sicle of the upper lip of the young "White-beaks". Grieg found bristles on a male 2.05 metres in length. 
In the full-grown embryo, the dark, blue-black colour extends from the region above the snout (beginning a few centimetres above the beak-furrow) over the whole of the back, - with large or small patches of a lighter shade erery here and there. - and stretching out over the whole of the dorsal surface of the tail-fin. The lower boundary of this dark shade of colour is from the angle of the mouth to the axil, and backwards along the lower part of the flanks on a level with the shoulder-joints, as far as the region behind the anus, where it also includes the rentral portion of the post-anal segment of the body. The pectorals, the dorsal fin and the tail-fin are the darkest parts. The unpigmented or white portion of the body extends from the snout a little abore the beak-furrow, over the whole of the lower jaw, the chest and the abdominal surface, ending in a point behind the anus. From thence it runs as a greyish white colour with darker patches, along the rentral ridge of the tail, spreading out in a lighter shade over the inferior (ventral) surface of the tail-fin.

The light patches and shades peculiar to this species are distributed in the following manner in this embryo. An oral patch on the back of the neck on each side of the black medial streak, extending from the crown of the head (immediately behind the nasal orifice) to a spot on a level with the pectorals, i. e. about midway between the nasal orifice and the dorsal fin. The side-patch previously mentioned as being found on the smaller embryo, is also strongly marked on the full-grown one. but on the latter, broken by darker shades and slightly marbled, it extends from above the pectoral to the region surrounding the eye, without however having the distinct limit characteristic of the full-grown animal. A third characteristic lighter part is the lumbo-caudal patch which includes a large part of the sides of the posterior half of the hody. It spreads from the middle of the body (on a lerel with the dorsal fin) orer the front portion of the post-anal segment, with a delicate light shade under the post-anal dorsal comb.

A small portion of the foetal membranes was hanging to the full-grown embryo. The umbilical cord measured 52 centim. in length and from 1.5 to 2 centim. in thickness, with few twists and only one or two small prominences here and there. The allantois might be traced as a hollow, cylindrical. thin-walled string into the umbilical cord, and peripherally a little of the expansion of its carity along the inner surface of the chorion to both sides of the umbilical vessels. The uterine surface of the alherent pieces of chorion was very meven. At first sight it gare the impression of a rery rough, wrinkled piece of serge. the whole surface, which lay in long folds, being thickly corered with either leaf-like, or more rounded, fringed, wart-like prominences, which represented the chorionic villi. On the fœtal surface of the chorion might be seen with the naked eve a thick ramification of ressels, corered, to a great extent, by the amniotic sac, with a little subchorionic tissue between. The actual tissue basis of the chorion was rery thin. 

II.

3.

GUSTAV GULDBERG

\section{EARLIER STAGES IN THE DEVELOPEMENT \\ $\mathrm{OF}$}

PHOCENA COMMUNIS, LESSON.

PL. IV., FIGS. 1-21. 



\section{Phocrena communis, Lesson.}

P1. IT.

$\mathrm{O}$

account of the frecquent occurrence of the common Porpoise on all European coasts, it has been employed almost as a paradigm when the anatomy of the Cetacea has been in question; and from the time when Thomas Bartholin (14) dissected the gravid Porpoise in the presence of the Dano-Norwegian king, Frederick III, until our own day, scarcely any Cetacean has been so much examined. In this way the Phoçena has served as the subject for Rapp's anatomical description (3i) of the ('etacean type. while its external form and occurence are treated of by many older naturalists. Kiikenthal (js. II Theil) has lately given descriptions of the external form of quite small embryos; Klatsch (5j) has described its fretal membranes; Iames Grieg (83) with splendid material for his hasis, has treated thoroughly the question of the duration of its gravidity; while P. J. Tan Beneden, on a ground-work of old and new obserrations, has giren us its "histoire naturelle".

While I pass orer the rather diffuse literature of this species and direct attention on that point to the well-known works of Rapp. ran Beneden (St, Lill jeborg (T2) and others. I will. in addition to the description of the small embryonic forms of Lagenorhynchus acutus. Gray. supplement our knowledge of the earlier stages of the Odontocetïs derelopement, by a description of an embryo of this species $\bar{i}$ millim. in length, another $1 \bar{r}$, and a third 18 millim. in length. The first of these, the i millim. long fietus. proved to be well preserved as far as its external form was concerned, and represents not only the smallest specimen, but also the earliest stage of developement hitherto described of any Cetacean. The $\bar{\tau}$ millim. and the 17 millim. long embryos were taken by Mr. Bistrup, Sukkertoppen, Greenland, in 1892.1)

I. The smallest Phociena embryo. preserved in alcohol, was enclosed in a double amniotic bag, while the long chorion was open. The length. measured from the Hexure of the neck to that of the tail, was $6 \frac{1}{2}$ or 7 millim.

On opening the amnion and stripping the embrro of it. the latter proved to be in an exceedingly well-preserved condition.

The embryo (Fl. IT. figs. 1 and 6-12) resembles; as regards its degree of derelopement. a human embryo of about $t$ or 5 weeks. In addition to the marked fretal flexures, this stage of developement is distinguished by the pronounced visceral arches with risceral groores. the incipient olfactory depressions, the but slightly differentiated eye derelopement, the long. bent tail reaching to the facial region. and the formation of the extremities, the distinct bud-like rudiments of hind-extremities being undoubtedly among the most interesting conditions of external form in the developement of the Cetacea.

The furtal flexures in this small fietus are as marked as those in an embryo rabbit of 10 or 12 days, or an embryo log of 25 days. 'Thus the Hexures of the crown of the head and the back of the neck arte each bent in a right angle. The bend of the tiril describes an arc of $180^{\circ}$. The neck and chest regions lie close to one another, and the relatively rery long, crlindrical tail extends as far as to the anterior part of the head.

The head. measured from the flexure of the crown of the head to the middle of the neck flexure, is about $3^{1 / 2}$ millim. in length. while the distance from the rentral surface of the facial region to the crown of the head is about $2{ }^{1 / 2}$ millim. The thickness. i. e. from side to side, is about $2^{1 / 2}$ millim.

The upper surface of the head presents no eren surfaces. Through the thin, transparent skin corering, in the region between the cromn of the head and the flexure of the neck, the relatirely large forea rhomboidalis (Pl. IT, fig. 9) is risible. The flexure of the crown of the head and the region in front of it are inclosed in an elongated oral arch that is connected with the mesencephalic resicle. and before this on the front of the head, may be distinguished under the integuments,

1) These two embryon and a small Phoca grünlandica fotus were sent. together with several other zoological specimens, to Prof. R. ('ollett. Who transmitted the embryos to the Zoutomical Museum. Dr. J. Hiort, the keeper of that museum. gare them to me for examination. for which act. I otter him my best thanks. 
an oral eleration elongated transversely. which is the anterior primary cerebral resicle, with indications of a division in the middle. forming the two resicles of the hemispheres (fig. 11 h. m.). On the rentral surface of the head - the face - may be plainly seen below the elevation of the fore-brain resicle, the fronto-nasal process (Stimfortsatz, Kölliker) with a hroad depression in the median line, forming on either side a large. oral prominence (the nasal prominence) with a cleft-like opening. viz. the olfactory pits fig. $11 \mathrm{Ng}$.). These are situated at a distance of about $1 \frac{1 / 2}{111}$ illim. from one another, and form an oval depression of about $1 / 2$ millin. in length, situated transversely in relation to the long axis of the body, and contracting towards its lateral end into a narrow groove (fig. 11) which opens into the boundary groove of the maxillary process (the lachrymal groove. fig. $11, \mathrm{~b})$. The olfactory pits are bounded by raised lips. The narrow groove ruming laterally from the olfactory depression may be explained as the "olfactory groove" (Nasenfurche, Källiker") It does not. however; open directly into the orifice of the mouth. but into the lachrymal groove ruming from the mouth cleft up towards the eye, which defines the maxillary process mesially.

We thus notice from the very first a transrersely situated olfactory depression. by which we can distinguish between the "superior" and "inferior" nasal processes, corresponding to the "external" (laterai) and "internal" (mesial nasal processes in man and other mammals.

Below the nasal orifices, the median region is occupied by the broad mouth cleft which expands upwards and downards in the median line. The earity of the mouth seens to form a conical depression behind in the direction of the back of the neck. Where it closes. A slighter depression in the floor is probably the opening to the fore-gut. The orifice of the mouth is bounded on each side laterally by the but slightly prominent "maxillary process" (figs. 6, 7 and $10 \mathrm{~m}$. $\mathrm{x}$.), above and laterally by the lower margins of the olfactory depressions. Thins in this stage of developement, in opposition to the subsequent ones, there is only a short distance between the olfactory depression and the orifice of the mouth. The latter is bounded below by the first visceral arch, or mandibula, which here lies against the chest region (figs. 10, 11, m b).

On viewing the side surfaces of the head (figs. 6, 7 and 10), a shallow depression is seen above the maxillary process, and behind the olfactory depression; in the shallow depression a slight convexity is conspicuous - the cornea (fig. 11,0). The invagination of the lens has probably taken plare a slort time before, and the eyeball has not yet adranced very far, only a very slight protrusion of the cornea being noticeable. There is, as yet, no trace of pigmentation in the eye.

In a profile riew (figs. 6, 7 and 10), the first visceral or mandibular arch is distinctly seen, with its relatively broad and short "maxillary process". This latter is separated from the eye and the lips of the olfactory depression by a shallow groove, as before mentioned. The mandibular arch is thickened and rounded in its transition from the side to the rentral surface. where it tapers towards the median line. A slight depression indicates the symphisis in the middle (see fig. 11).

The first visceral cleft has the appearance of a narrow, but distinct groore separating the mandibular from the lyoid arch (fig. 10). There is no indication of small prominences separated by shallow depressions such as might represent the first rudiments of an external ear (auricula).

The second visceral or hyoid areh (fig. $10 \mathrm{hy}$ ) is shorter and a little narrower than the first visceral areh; its rentral portion lies close in to the chest, and could not therefore be more closely exanined in the embryo while uninjured. This arch is bounded caudally by a relatively large, and alout $1 / 2$ millim. broad, rounded depression (fig. 10, fp), which is triangular in shape with its base towards the 2nd risceral arch, its apex pointing in a caudal direction and all its angles rounded. The dorsocaudally situated portion of this depression is still more hollowed out into a little blind foramen, of which the bottom is distinctly visible. The part of the triangular depression lying nearest to the hyoid arch is the 3rd visceral arch. This depression may also. from its situation and relations, be supposed to be the bend of the throat, sinus cervicalis (s. pracervicalis). It is surrounded by a little wall - limbus (fig. 10, fp).

The trunk. From the Hexure of the neck down to the bend of the tail, the series of protovertebræ may be distinctly traced externally; viewed either from the back or side (figs. 6-8). About 0.7 millim. below the curve of the throat, the fore-limbs spring out. Tentrad of these, the chest bulges out, and a lind of external boundary between the chest and heart region. and the abdomen proper is formed by a narrow groove running from the upper proximal end of the foreextremity in a ventral and caudal direction. But the chest region is also divided by a short vertical groove into a more projecting ventral part (cor) and a narrower dorsal part which is continued dorsally (i. e. caudally) helow the bend of the throat.

The sides of the body are moreorer separated by a shallow, dorsally-situated furrow ruming parallel with the curve of the back. - the "dorsal side-groove" - from the dorsum proper. The shallow "ventral side-groove" starts from the axil. and runs obliquely downwerds (caudally) and ventrally to the side of and below the funiculus umbilicalis, by which the abdomen proper is separated from the Hanlis.

Not far beyond the umbilicus, caudally, the curve of the tail begins, the body here describing an arc of $180^{\circ}$ in passing into the tail.

The tail which is conico-cylindrical, gradually tapering towards the point, is bent up against the ventral surface of the body and reaches almost to the face, although the end of the tail has a slight rentral inclination. Tmmediately below 
the insertion of the umbilical cord on the ventral surface, a triangular. rounled, genital eminence projects, - the tuberculum genitale (fig. 6, $\mathrm{t} g$ ). A little rorsad of the genital eninence at the root of the tail, ristinct external rurliments of hind limbs project from the sire surfaces of the borly. The distance from the root of the tail to the point is about 4 millim.

The extremities. The fore-limhs. $1 \frac{1}{2}$ millim. long and 1 millim. broad (figs. 6 and $7, \mathrm{f} .1$ ), are of a rounded, padrle-like slape, the base being a little narrower than the flat and bud-like free end. There is a slight indication of division into two segments. The long axis of the fore-extremities runs obliquely in a eaudal and ventral direction. There is no external indication of finger rays.

The hind-extremities (fig. 6 and 7. h. e. and fig. 12, h e) are 0.75 millim. long and 0.60 millim. broad, and are like oval leaves in shape, narrower at the base. The free, rounded margin is turned ventrally and a little laterally outwards, while the attached hase is situated on the flanks at the junction of the trunk with the tail, ventrad of the dorsal side-groove. The proximal end lies on a level with the cephalic margin of the genital eminence, and therefore far below or caudad of the umbilicus. 'The long axis of the extremities runs in an obliquely caudal and ventral direction (fig. 12. h. e). The position of these small hind-extremitios thus agrees completely with what we know of the embryos of other manmals. They are. however, scarcely more than half the size of the fore-extremities, a point of difference between these and other mammal embryos, in which the hind-extremities, thomgl dereloped somewhat hater, are not far behind the fore-limbs in point of size; even in the early stages of derelopenent. On making serial sections through the right hind-extremity, it proved, on microscopical examination, to consist of undifferentiated mesoderm tissue without sharp separation from the epidermis: in some places small vessels were observale. - We thus have before us an embryonal elementary form. which is at first small and slender, showing no tendency to powerful developement. Compared with the embryos of quadruped mammals. there is already a great difference in the first commencement of the organ in this respect. When the rudimentary hind-extremities :lre compined with the same embryo's relatively large, powerful tail, we also find a striking contrast in the developemental tondency of these organs, the hind-extremities, which are destined to disappear, being, from their earliest appearance, weak and small, while the tail. which afterwards becones the animal's chiel organ of locomotion, and, as such. displays a high degree of developement and functional adaptation, is found, even in the earliest stages, in the front rank of the external of the body, on account organs of its powerful elementary character and rapid growtl.

The umbilical cord is $1 \frac{1}{2}$ millim. in diameter, and very short, between 2 and 3 millim. in length, its reins soon being absorbed into the fortal membranes. The amnion is attached about $1 \frac{1}{2}$ millim. outside the abrominal insertion of the minbilical corrl.

From the cephalic margin of the navel, or in other words, the margin nearest the chest region. projects a rery marow cylindrical process, about 2 millim. in length, with a slightly chub-shaped, expanded free end (fig. 12, v. u.). This I take to be the vesicula umbilicalis, which is connected with the gut by a short ductus omphalomesentericus.

General lemarks. This smillest Phocena embryo, which may be said to measure about $1 \pm$ millim. when the listances between the fortal Hexures are added together, presents all the characters in their general form. and as we are aconstomed to tind them in other mammal embryos in a corresponding stage of developement. One peculiarity which may be noted is that it is rery small and slender. a human embryo of about the same degree of derelopement being both longer and consideribly thicker. The size of the lead, moreover, seems to be small in proportion to the body, while the tail is musually long. As alrealy indicated. the rudiments of the hind-extremities are rery small in proportion to the fore-limbs, when comprided with the embryos of four-footed Mammals; and though the external form of the limbs in this Phocena fortus loes not. on the whole, seen to differ from the ordinary embryonal limb form. I comsider the paddle-like shape of the hind'xtrenitics to be somewhat characteristic. The transversally situated olfactory depression also scems to me to be characteristic, and perhaps already denotes an Odontocete character. At any rate, the shape of the nose here differs distinctly from the shape of that organ in a somewhat larger fortus of Ploca grönlandica (17 millim. measured from the tlexure of the head to the tail), where the nasal cavity has a rertica? direction, while in the Phocena the olfactory groove opens transrersally into the more vertically rmming lachrymal groore. - The powerfully dereloped tail is a peculiarity which was also conspicuous in the 8 millin. long Lagenorhy yelus acutus embryo. We may see in this an expression of the apparently general law in the derelopement of the organs. that an organ which plays a y conspicnoms part in the independent existence of the animal (of the species. the genus. the fanily, etc). appears carly, and even in its first embryonil developement makes a rapid sowth, and asimmes a nore or less proninent position (e. g. the eye in birds, the fore-limb in the bat, the brain in man).

II. The Plocitna embryo, that is scarcely 17 millim. in length. measured from the thexure of the head to the hend of the tail, resembles greatly the succeeding one. showing, lowever, in sereral particulars, a far less advancerl condition of clevelopenent. although the difference in length - about 1 millim. - is very slight (Pl. IT. figs. 2. 3, 13-16).

'The fotal filexures are less marked than in the preceding specimen, but more so than in the 18 millim. long embryo (Pl. IV. figs. 17 and 18). The Hexure of the neck (fig. 13. n) forms an angle of $130^{\circ}$ or $140^{\circ}$ with the long axis of the body, 
and the head flexure about the same. the crown of the head being the highest point of the body. if the fartus be imagined in a rertical position. The tail flexure is much less than in the previous starlium. and the tail itself is relatively much shorter. The umbilical cord is attached at the transition from the middle to the hindmost third of the borly.

The head. Although the craninm certainly forms the main part of the head. the face region has already made decided adrance. A shallow furrow is formed in front. - the frontul frorow (fig. 13. fí). - diriding the fore part of the cranium from the face. this furrow being traceable almost to the upper border of the eye-region. The surfice of the cranim exhibits slight prominences corresponding to the brain vesicles, one slight swelling being fonnd on the frontal portion of the hear corresponding to the liemispheres fig. 13, he), another on the crown for the mesenceplaton (fig. 13, m), in front of this the thalamencephalon (fig. 13, the) and a depression between the crown of the hear and the flexure of the neck. answering to the the rentricle (fig. $15 \mathrm{f}$. rh). Through the integuments, the forea rhomboidalis is distinctly discernible in outlines fig. 15) which show excedingly large lateral prominences, and also the elongated medulla oblongata and the spinal cord below the flexure of the neck.

Seen in profile (figs. 13 and 16), the facial region constitntes a very small part of the head. It is howerer, noticeable that the upper jal is rery predominant. - an indubitable Cetacean character which has begun to assert itself

The eye is situated on a lerel with the nasal orifices. The length from the imer to the outer angle of the eye measures $1 \frac{1}{2}$ millim.. the height being much less; the eyelids have hegun to appear in the shape of little folds of skin, and the pigmented iris is listinct. Within this, several fine rings are visible, while the centre is occupied by a white spot - the pupil (figs. 13 and 16).

The nostrils (fig. 1t), each about 1 millim. wide, are 2 sigmoid, transrerse fissures, connected in the median line by a shallow groove. In this point they already exlibit a marked Odontocete character. The distance between them is relatively large. but the shallow connecting groove already denotes the incipient external fusion. as it is found in more advanced embryos. While the distance between the nostrits and the frontal furrow is rery small. we see, even at this stage of developement, the rapid growth of the upper jaw, which projects and separates the nasal orifice from the month orifice.

The orifice of the mouth is tumed towards the chest. and cannot be fully seen, only a small part of the corners of the mouth being visible at the sides (see figs. 13 and 16). It is abont $4 \frac{1}{2} \mathrm{millim}$. broad. The lower jaw is but little dereloped. and is overhung considerably (about 2 millim.) by the already greatly projecting upper jaw.

The external ear aperture, from 0.75 to 1 millim. in diameter, is situated 1 millim. above the fore-limb and 2 millim. belind the corner of the mouth. obliquely below and behind the eye. The aperture is fumnel-shaped, oral, sharply defined in front, but more open behind. The small auditory pussage is situated in the lower part of the oval depression (figs. 13 and 16). The whole of the external ear aperture is surrounded by an exceedingly slightly-marked, amnular eminence which has a smooth and even surface, without any trace of small prominences or depressions which might denote an incipient external auricula.

Just below the head, at the constriction of the neck. the fore-extremities protrude (Fig. 13, 1t, 16). They are 3 millim. long. and lie flat against the side of the body; they consist of a narrow proximal part, scarcely 2 millim. broad. and a broader distal part. $2^{1 / 2}$ millim. in width, the latter being of a rounded, paddle-like shape. In the broader distal end, 5 dirergent finger-rays are distinctly discernible.

On the back. the spinal cord is distinctly seen through the integuments (fig. 15), begining immediately below the flexure of the neck. where it exhibits a narrow and as it were constricted part. which, however, expands just below into a slight but definite intumescence. (intumescentia cerricalis) on a level with the fore-limbs (fig. 15. ic.). The spinal cord is risible superficially right down to the tail flexure. Before it reaches that point, there is an indication of a faintly defined enlargement (lumbar intumescence. fig. 15. i 1.).

On the surface of the back on each side of the spinal cord visible through the integuments, is a "lateral backfurrow" rumning parallel with the median line. 'This furrow extends from the flexure of the neck down to the tail. On the sides of the body: and especially at the level of the umbilicus, a lateral side-furrow is distinctly apparent (fig. 13 and 16 ). Nearer the ventral surface, a "ventral side-furrow" denotes the boundary between the side plates and the membrana remiens anterior. This boundary furrow extends from the neck down to the region immedjately above the membrum genitale (fig. 14). The rentral surface is very convex; as is usual at this stage of derelopement, and its lower portion is occupied by the origin of the funiculus umbilicalis.

The membrum genitale is about 2 millin. long and very projecting (fig. 13, g). It forms a slightly curved cylindro-conical prominence, the broad base of which occupies the space between the concavity of the tail flexure, and the lower boundary of the membrana remiens anterior. On the under side is the legitimate groove (hypospadia), which passes posteriorly into the orifice of the sinus urogenitalis.

A little dorsad but at the base of the membrum genitale, are visible on each side. 'two small tubercles, which are connected at their basal origin, and project about $1 / 3$ millim. (Fig. 13 ll e, figs. 14 and 16). The upper tubercle is 
smaller than the lower. a circumstance which is especially noticeable on the left side. These external prominences are to be intcrpreted as rudimentary external hind-extremities, their situs and relation to the membrum genitale being in agreement with what we have descriled in the preceding embryo. These rudiments of hind-limbs are unduobtedly in a state of retrogression in this embryo, and must thereforebe regarded as embryonic, disappearing rudiments.

It should be remarked, that where as these rudiments of extremities at this stage are on the point of disappearing, the Cetacean characters have begun to develope, a few being already rery prominent.

The tail, cauda, is relatively much smaller in this embryo than in the preceding one, the length from the hind limbs to the point of the tail being 5 millim. It has now assumed a more conical form, and the ventro-dorsal diameter is greater than the transrerse. It is bent ventrally, and points in a cephalic direction.

General remarks. It would have been desirable to hare had examples of intermediate stages of developement between this 17 millim. long embryo and the preceding one, for this one comes very close to the succeeding 18 millim. long embryo. The usual form of mammal embryo is naturally found here, but there is also an admixture of special Cetacean characters. For instance, the peculiar shape of the external nostrils, differing as it does from that in the ordinary MIammal embryos must be regarded as Odontocete; the distance between the nostrils and the cleft of the mouth is relatively great; and the tapering of the body torards the tail. which continues the trunk without any sharp division, and the absence of hind extremities characterize the more ordinary Cetacean. The vanishing remnants of hind extremities are among the most characteristic conditions of this stage of derelopement.

III. The 18 millim. long Phocana embryo, taken on the 19th Sept. 1888 (Pl. IT, figs, 17-21) is rather more fully dereloped than the preceding one. The foetal flexures are still, on the whole, strongly marked, especially those of the crown of the head, the neck and the tail (Pl. IT, fig. 18), although less so than in the 17 millim. long foetus. The hear. measured from the crown to the lower jaw is contained $21 \% 2$ times in the total length of the body. Compared with the 26 millim. long Lagenorhynchus acutus embryo, the little Phocena foetus gires the impression of being somewhat earlier and less developed. Compared with the 25 millim. long Phocæna embryo figured by Prof. Kükenthal, it shows, in addition to its inferior length (1S millim.). a more embryonic character in its external conditions of form.

'The hear. although much hent towards the rentral surface, permits a riew of the orifice of the mouth (fig. 17). The cleft of the mouth produced backwards intersects the axis of the back at an angle of about $40^{\circ}$, and the bent conical tail forms almost a right angle with the long axis of the back. The distance between the orifice of the mouth and the mostrils is relatively smaller than in the 26 millim. long Lagenorhynchus embryo; above the nostrils there is a distinct frontal furrow (figs. 17, 18 and 19); moreover the head is of a spheroid shape; the facial region occupying only a very small and but slightly projecting part. although more distinct and better defined than in the 17 millim. long foetus. The eyes lie proportionately high up towards the cranium, dorsad of the angle of the mouth. The relatively large, open eyes $\left(1^{1 / *} \times 1\right.$ millim.) with the erelids still only in their commencement. exhibit a blue-pigmented iris.

The extemal nasal apertures (fig. 19) exhibit no rery great difference from those in the preceding specimen, appearing. as they do, as $2 \mathrm{small}$ clefts. anteriorly concare, which are in contact with one another at their mesial ends, where a shallow groove is obserrable along the median line. The distance in a straight line of the nasal apertures from the cleft of the mouth is $21 / 4$ millim. This Phocrena embryo is in conformity with the 26 millim. long Lagenorhynchus foetus in the mamner of the commencement of the external nostrils. and also in this respect follows naturally the two earlier Phocæna cmbryos described above, namely. that the external nasal apertures begin, exactly as in other mammals, as two separate openings which are fused secondarily into one transrerse fissure in the Delphinidæ. It is interesting to note that the primary opening is already transrerse and not longitudinal. In the little Phocrena foetus described by Kükenthal. the fusion had already commenced.

The external ear aperture is situated $21 / 2$ millim. below and behind the angle of the mouth and only a little above the production of the inferior margin of the lower jaw (fig. 18). The opening appears like a small $1 / 2$ millim. obliquely situated (from above downwards: from thie back forwards. when the foetus is imagined in a perpendicular position) elongated oral fissure. orerhung dorsally by a low limbus (see figs. 18 and 21). so that the whole measures about 1 millim. in length. On the other hand there is no prominence or papilla to be seen, on which the ear aperture lies. nor could I distinguish node-like prominences surrounding it. as described by other naturalists. The real entrance to the extemal anditory passage is thus situated in the dorsal region. or the region nearest the head. in a little depression. There is perfect conformity between the right and left sides. ${ }^{1}$ )

The cleft of the mouth is 4 millim, broad. and turns downards and forwards. The prolongation of the fissure

1) I cannot subrtantiate Kükentlat's declaration (lit. 58. p. 352) as to the dissmmetry of the ear, or the presence of the "sechs Hügel". On the other hand. I would say nothing anainst the general dissymmetry in Cetacea. easily substantiated by all. 
backwards passes between the eye and the ear aperture. The upper lip, abort the fissure, projects beyond the mouth and the lower jaw. The latter has a triangular depression below the mouth cleft (Fig. 19).

The constriction of the neck, which seems to be characteristic of Dolphin embryos in their earlier stages, thus recalling small embryos of terrestrial mammals, appears here in the same manner as in the 26 millim, long Lagenorhynchus embryo. At the back of the neck, there is a depression corresponding to forea rlomboidalis. The fore-limbs project just below the constriction of the neck.

The fore-extremities (fig. 19) have ahmost the same shape as those in terrestria! Mammal embryos of an early stage of developenent, namely a short, broad arm, with the distal portion broadly rounded and paddle-like: the medial surface is turned towards the chest. On the distal, paddle-like part, 5 short, divergent finger rays are seen through the skin.

The dorso-rentral diameter of the trunk is longer than the transverse diameter. The edges of the back are comparatively straight. while the rentral surface and sides form convex lines of contour. 'The embryo's ventral surface, as in the preceding example, is a very convex part. with its boundaries clearly defined by a ventral side furrow (fig. 18). The convex abdominal region is corered by the membran a reuniens, while the ventral side furrow indicates the boundaries of the adrancing muscle plates. There are no other furrows to be seen on the sides of the body, except a slightly marked side furrow, dorsad of the fore-extremities (fig. 18), and a back furrow parallel to the median line. There are no transverse furrows or prominences on the side region on a level with the umbilicus and the genital organs.

The navel. situated in the lower part of the ventral area, measures 3 millim. in a cephalo-caudal direction. In the hardening process, its sides have been compressed.

A little below the rentral area which is covered by the membrana reuniens. is situated the membrum genitale (figs. 17. 18 and 20) which is thickest at the base and tapers forwards. It projects below the navel and forms a concavity downwards. On the under side is a groove (fretal hypospadia).

At the base of the membrum, a little below its root and attached to it, the skin is seen to be slightly raised. Somewhat beyond. laterad of the base of the membrum a small skin prominence is observable (fig. 20). This I explain as the finally disappearing rudiment of an external hind-limb. On first noticing this. I was inclined to take it to be the first commencement of mamms, thongh I could not affirm it with certainty until I could convince myself, by serial sections throngh that region. of the actual conditions. When, however we compare these external conditions of form with those in the 2 earlier Phocsena embryos and the Lagenorhynchus embryo, the explanation is clear. The small prominence which is situated laterally as regards the base of the membrum, has exactly the same relative position as the soon-to-disappear, external rudiment of a hind-limb in the 17 millim. long embryo, while the proninence within, close to the base of the genital member is the incipient fold of skin. which becomes the labia majora resp. the skin sheath for the penis. Upon or by these begin to appear somewhat later the manmce pudendales. These, in my opinion, are a formation which first appears when the rudiments of the hind extremities have almost disappeared.

The transition from the truncus to the cauda, thongh not abrupt. is rapid. The cauda is cylindro-conical, and measures $3 \frac{1}{2}$ millim. in length from the anus to the apex. It forms ahmost a right angle with the long axis of the body.

General remarks. This 18 millim. long Phocxna embryo, which differs only slightly from the preceding 17 nillim. long embryo, is. however. more developed in its specific Cetacean characters, while it still recalls, more than the 26 millim. long Lagenorhynchus fietus. embryos of terrestrial Mammals in its general form, the constriction of the neck, the general paddle-like shape of the fore-extremities. and the ordinary fietal flexures. As special Cetacean characters may be noticed the position of the external nostrils high up on the face, and their transverse cleft form, which is a Dolphin characteristic. the simple external ear, the absence of hind-extremities, and the relatively long cauda, which passes without any decided boundary into the trunk. The early developenent of the membrum genitale is also peculiar to the Cetacea, according to the experience I have up to the present acyuired.

From the abore description of the small Phocena embryos, together with the facts learned from the Lagenorhynchus embryos. we may atfirm that rudimentary hind limbs begin to appear in the Delphinida in an oval, rmnded, paddle-like shape at a very early stage of developenent, vix. while the visceral clefts are distinct. Their position on each sile of the body is on e level with the genital tubercle, and corresponds exactly with the place where the external commencement of hind-limbs generally appears in the higher vertebrate animals. From the rery begimning they are small, and appear like tiny. thin superficial appendages, scarcely half the size of the forelimbs. They are soon left behind in developement, and undergo a retrogressive process; so that their presence as superficial appendiges is only temporary. As they disappear, the Cetacean characters appear, and when they hare altogether disappeared as superficial appendages. the first commencement of a mammary organ is to be found. In contrast to the temporary superficial hind-limbs, the tail, in the earliest embryonal period, is found as a rapidly developing external organ. The fact that special characters, indicating the direction of the developement, appear so early, ought also to be noted as a property of perhaps general force. 
It will be evident to all that the above-stated embryological facts may also serve as a support for phylogenetic hypotheses. One may thus be led to suppose that the hind limbs in the Odontocete progenitors, e. g. the Zeuglodon, must have played a very insignificant part, perhaps even less than was the case in those fossil reptile types, whose form of limb forms a parallel to that of the whale, e. g. Ichthyosauri. Indeed we come involuntarily into the question as to whether any true Archro-Odontocete has had lind-limbs in use, inasmuch as they disappear embryologically, before the more important Cetacean characters make their appearance. I cannot, of course, venture to draw any decided conclusion from the above facts, but I consider myself entitled to bring forward the question, which still remains open. - The abore-stated embryological discorery of an early developed tail is in perfect agreement witl palæontological facts, as they both point to the circumstance that the recent Cetacea are descended from animals with a powerfully developed tail, which must have played an important part in swimming. Flower's supposition would thus be powerfully supported. When W. Dames (61), in his interesting work on Zeuglodon Osiris makes this assertion: "Die Anpassung an das Wasserleben nahm also ihren Anfang an den beiden Enden des Körpers und schritt am hinterm Ende, dem motorischen Pol, schneller vor als am vordern Ende, dem Nutritions Pol", etc., the embryological facts do not contradict it, in so far as the Cetacean characters do appear at first at both ends of the body; but on the other hand, I nust lay stress on the fact that such decided conclusions cannot be drawn from embryological as from palæontological data, the latter being, indeed, always the most reliable corrector in our phylogenetical hypotheses; for during the ontogenetic derelopement, so many factors assert themselves, that we can never venture to place the "palingenetic" in the foreground, if the conchusions are to be temperate. If we place these early stages of developement together with those of Lagenorhynchus acutus already described, we come once more to the theory, that the embryo's developement proceeds by the shortest road to its goal. 

II.

4.

GUSTAV GULDBERG

\section{SOME STAGES IN THE DEVELOPEMENT}

$\mathrm{OF}$

ORCA GLADIATOR, LA CÉPEDE.

PI. V,

AND LETTERPRESS FIGS. 3 AND 4. 



\title{
Orea gladiator, La Cépède.
}

\begin{abstract}
A
lthough this Odontocet, according to $P$. J, van Beneden ${ }^{1}$, was known as long ago as in Pliny's time, and is named by all older naturalists who have turned their attention, to any great extent, to the Cetacea, yet the question as to whether this "tyrannus Balrenarum", as Fabricius calls it, is represented by one, two, or three species in the North Atlantic Ocean, has only in the last decennium, we may venture to say, approached a solution. While Lütken²) considers $0 \mathrm{r}^{2} \mathrm{ca}$ grladiator and Orca minor (Schlegelii) as one and the same species, and leares the subject of Orca Eschrichtii untouched, being inclined to look upon it as a separate species, P. J. van Beneden (1. c.) goes much farther in the dentification of the various species. He says: „Non seulement nous croyons de voir rapporter tous ces Orques des mers d'Europe ì une seule et même espèce, mais nous croyons de plus pouroir y rattacher les Orques du Pacifique, comme ceux ide nos antipodes."

As far as I am aware, very little is known about the tmbryos or foetuses of this species.

Melchior. (Den danske Stats og Norges Pattedyr, 1834, p. 281) makes a remark about its breeding, and states that in 1829, three grampuses were killed on the coast of Jutland, one of them being a $20 \mathrm{ft}$. long female, which bore :a fully-developed foetus of the size of a full-grown porpoise" (i. e. $6 \mathrm{ft}$.). His statement that it breeds in the antumn, and, like the generality of whales, gires birth to only one young one, is repeated by many subsequent writers.

Sir William 'Turner describes a foetus, 36 inches long (ca. 0.94 metre).

Although I can say nothing about the earlier stages of the Orca's derelopement, I thought it incumbent on me to make use of the exceptionally copious material which the Bergen Nuseum contains for the inrestigation of Orca foetuses in the later stages, and to give an account of the developement of the outward form and colouring.

The following foctuses from the Bergen Museum hare served as types in the present description:

A female fortus, 408 millim. long (from Bildøen, in the beginning of Feb. 1885).

A male fuetus, 615 millim. long (from Bildsen, Feb. 1885).

A female foctus, 875 millim. long (from Bildoen, Feb. 1885).

In addition to these, I subjoin a description of a young one, taken on Jan. 26th 1891. It is 2.51 metres in length, and its age may be computed at from 1 to 2 months. The animal's skin has been stuffed, and its skeleton placed in the Iniversity Museum in Christiania.
\end{abstract}

1. The 408 millim. long female Orca embryo (P!. V, fig. 1) exhibits some amount of fœtal head-flexure. The Orca character is already apparent in the short, thick snout, the rounded shape of the head, the short, almost straight mouth fissure, and the blunt, leaf-like pectoral fins. The long axis of the head forms an obtuse angle with the long axis of the body, and its length amounts to rather less than ${ }^{1 / 4}$ of the length of the body. The snout portion of the conrexly rounded upper jaw, with 4 fietal lrairs situated far above the cleft of the mouth, is short and thick. The upper convex line of contour of the head forms a concarity at the external nasal aperture (see Pl. Y fig. 1). The cleft of the mouth is short and straight. The eye fissure lies more than 1 centim. higher than the angle of the mouth. The distance between the eve and the ear aperture amounts to ${ }^{1 / 1}$, or ${ }^{1} 1$, of the length of the trunk (in the full-grown animal to $1 / 12$, according to Lilljeborg). The posteriorly concave nasal orifice lies in a hollow and is bordered by raised lips. The transversal plane through the nasal aperture intersects the anterior angle of the eye.

\footnotetext{
1) Histoire naturelle des Delphinides des Mers d'Europe. 1889, p. 33.

") Kritiske Studier over nogle Tandhvaler. etc. Danske Vid. Selsk. Skr.6te Rakke, naturr.-mathem. Afd. IV-6.
} 
The pectoral fins. 59 millim. long, are situated at the transition from the first to the second quarter of the trunk. They amount to nearly $1 / \pi$ of the length of the trunk (in the older male, between $1 / 5$ and $1 / 6$, in the older female, $1 / 8$, according to Lilljeborg; in the new-born female which will be described subsequently; the length of the pectorals is $1 / 9$ of that of the trunk). As before stated, the pectorals have already assumed the typical Orca shape; they are blunt, rounded and foliate: their greatest breadth is equal to nearly half their length.

The trunk is of a distinct spindle shape with its greatest thickness near the pectorals. The umbilical cord is attached in front of the middle of the body, and immediately beneath the foremost aseending margin of the dorsal fin. The post-anal segment is somewhat less than $1 / 3$ of the length of the body. and is characterised by distinct dorsal and ventral keels. - The dorsal fin is situated in the middle of the dorsal surface of the body; it is 26 millim. in height, with a slightly eonrex. retreating front margin. and a slightly concare hind margin descending almost vertically. The width of the dorsal fin at the base amounts to nearly $1 \frac{1}{2}$ times its height, and the hind margin is eontinued in the dorsal keel. - The tail fin is 85 millim. broad and $1 / 4$, of the length of the trunk, that is to say of about the same proportion as in the full-grown animal. It is triangular in form. with a small cleft and a very slightly sigmoid hind margin.

The colouring on this embryo, which further demonstrates the Orca type; is of special interest (Pl. r, fig. 1).

The typical "neck-band". appearing in the Lagenorhynchus embryos, also appears in the Orca, though somewhat indistinct in so slightly dereloped a fartus as the one under consideration. A dark band may be noticed in front of the eyes, stretching backwards and upwards orer the most convex part of the head. It deseribes a semicircle open to the front, and at the back of the head and neck exhibits a proportionately darker colour than the less strongly eoloured surrounding parts. On the head. the colour boundary shows conditions almost similar to those in the fully-developed animal, except that the colours are naturally not so dark. For instance, the region round the nasal aperture has still but little colour. The eye region is surrounded at the lack by a darker ring (fig. 1) and the eyelids have begun to be coloured, while the intermediate part is still rather light.

The colouring upon the trunk already exhibits, on the whole. the typical distribution peculiar to the Orca, but the boundaries are more indefinite. and in the caudal segment the pigmentation is rery little developed. The pectorals are of a blackish grey with the characteristic anterior transverse border. On the sides of the body behind the pectorals, the dark colour extends far down over the surface of the abdomen, into the region round the navel, while somewhat behind it, extending round the anus. is seen on each side the oval patch of white (fig. 1) typical of the Orca gladiator (fig. 2). The dorsal fin is almost black on its anterior convex border. but is lighter behind. Below and near the posterior margin of the dorsal fin an irregular: lighter pateh is observable, which indicates the spot where. in many full-grown specimens, a purple patch is found. - At the junction of the back with the sides. a blue-black line is found on each side running from the region behind the dorsal fin almost to the eye; it has a shightly sigmoid currature, and stands elearly out on the blue-grey ground. This narrow, strongly-coloured band. which begins above the foremost white patch by the eye, expands into the shape of a fan immediately behind the dorsal fin. and below the light part which is purple in the full-grown animal.

The white colour (i. e. the unpigmented part) is thus distributed orer the whole of the lower jaw, the extreme erges of the upper jaw. and the lower part of the head as far as the pectorals, where the line of demarcation runs almost rertically down to the axil. An oral white patch lies behind the eye. The surface of the abdomen is white between the pectorals. but helind them there is only a narrow white band along the median line until a little beyond the navel. Here, howerer, the white colour sprearls out to each side to form the characteristic large, elongated oral pateh of white on eaeh side of the pudendal and anal region. The greater part of the rentral keel and of the inferior surface of the tail fin is also white.

In comparing this fortus with the previously described Lagenorhynchus acutus foetuses, we find that it ought properly to be classed with those of about 20 centim. in length, where the length amounts to about $1 / 5$ of that of the new-born animal. The distribution of colour, howerer. in the above described Orca foetus shors greater derelopement and is more characteristic than in the corresponding Lagenorhynchus fretuses.

A considerable portion of the fretal membranes was adhering to this foetus; it will be described in a subsequent chapter.

II. The 615 millim. long frotus masc, exhilits in certain of the circumstances of its external form, and in the distribution of colonr. a further developement of the eharaeters enumerated in the description of the 40.8 centim. long foetus. "The head curve is rery slight. The length of the head is eontained $4^{1 / 2}$ times in that of the body; the navel lies a little in front of the midlle of the abdominal surface. The front part of the dorsal fin is vertically over the navel. The distance from the anus to the tail cleft - the post-anal seguent - amounts to rather less than $1 / 3$ of the length of the body. The pectorals are sitnated at the heginning of the second quarter of the body. reekoning from front to baek.

In fretuses of the size here described, the head has a more pointed snout. Seven foetal hairs may now be counted on each side of the upper jaw; they form a curve with the eonvexity downwards. The edge of the upper lip describes 
a slight sigmoid curre, and its hinder part orerlaps the lower lip, and extends so far back as almost to come beneath the antericr angle of the eye, which lies 2 centim, above. The external nasal aperture lies in the same transverse plane as the anterior part of the eye fissure.

The pectorals, about 9 centim. in length, amount to between $1 / 6$ and $1 / 7$ of the length of the body (in the younger male, to $1 / 6$ ) and the width is a little more than half the length. They are of the characteristic spatulate form.

The dorsal fin. 42 millim. in height and 61 millim. broad at the base, amounts to about $1 / 16$ of the length of the trunk. Its anterior margin is convex, its posterior deeply concave; its base is not sharply defined.

The post-anal segment is very much compressed, and has ventral and dorsal keels. The tail is about $140 \mathrm{millim}$. broad. its length being contained between 4 and 5 times in that of the body.

The somewhat constricted insertion of the umbilical cord is 18 millim. broad. The penis lies midway between the anus and the navel, and projects considerably from the prepuce; there is only an indication of the fold of skin into which it is sulbserguently withdrawn. About halfway between the anus and the penis. but rather nearer to the anus, are 2 small openings. which must be interpreted as the rudimentary mammæ masculinæ.

The colour in this embryo is more sharply defined than in the previous one. The darkest shade is found orer the hearl and the back of the neck as far as the dorsal fin; the next. round the eye and the borders of the pectorals. The rest of the coloured portion is not quite as dark. The black line on the upper front part of the back, which was mentioned in the description of the $t h$ centim. long fatus. is here also very distinct. though somewhat fainter in its foremost part. On both sides of the dorsal fin. especially at the posterior end. the colour is of a lighter shade, corresponding to the purple patrh observed on the full-grown animal. The yellowish white, wedge-shaped patch in which the anus and the penis are situated, is separated from the hindmost side-patch by a dark wedge-shaped patch rumning forwards. There is a little pigmentation on the preputium and on the fold of skin round it. as also a little on the umbilical cord nearest the insertion. The distribution of the white colour includes, as in the to cention. long foetus, the border of the upper jaw, the whole of the lower jaw. the throat region to a little above the shoulder joint, and the ventral surface; on the last-named, from the pertorals to some distance beyond the navel. the yellowish white part is rery narrow; but farther on, it enlarges to form the haracteristic oral side-patch. while the white colour in the median line forms the tongue-shaped part, in which the ants and the genitalia externa lie. Amost the whole of the inferior surface of the tail fin, with the exception of the edges and the extreme points of the flukes. is yellowish white. as is also the extreme end of the rentral ridge. The foremost light side-patch is bounded in front and below by the black part round the eye. It is of an elongated orial shape, and extends as far as the shoulder joint. Round the posterior axillary border there is a thinly coloured region of yellowish white mixed with grevish blue. while the dark pigment beneath the pectorals forms a forward-pointing, wedge-shaped patch. 'There is also a rather darker shade on each side of the yellowish white lower jaw.

III. The 87.5 millim. long female Orca foetus (fig. 3 in the letterpress p. 46 ) is of considerable interest. Its length is nearly halt that of the new-born animal, in other words nearly half-grown. The length of the head is a little less than $1 / 5$ of that of the trunk; on the mouth are 4 fatal hairs. the upper lip is of a sigmoid form, its hinder end stretching as far back as bemeath the anterior angle of the eve. The external nasal aperture is contained in a transrerse plane passing through the eye; the ear aperture is siturted nearer the axil than the angle of the mouth. The pectoral fins, 120 millim. in lengtlr, anromit to about ${ }^{1}$; of the length of the trunk, their breadth being about half their length. The trunk is relatirely narrow, with the greatest circmuference between the pectorals and the dorsal fin. The umbilical cord is inserted a little in front of the middle of the body; immediately under the tront part of the dorsal fin. The dorsal fin amounts to $1 / 15$ of the length of the body, and has a convex anterior margin, the point being inclined backwards. and the posterior margin very concave: the latter is continued in the shape of a low kecl. The postanal segment is less than ${ }^{1 / 3}$ of the length of the body. The 210 millim. broad tail fin (fig. 4 in the letterpress $p, t i$ ) amounts to rather more than ${ }^{1}+4$ of the length of the trunk. this being neal by the same proportion that they bear to one another in the new-born animal ( $1 / 5$ of the length of the trunk). There are distinct dorsal and rentral keels. The hind margin is only slightly sigmoid; the cleft is relatively deep and the flukes rounded.

The colouring of this embro (tig. 3), is developed to such an extent that the type of the species cannot be mistaken in looking away from the fortal characters. The black line on the back on each side of the cervico-thoracic part of the body is now less marked. and apparently forms the boundary-line between the strongly-coloured mesial dorsal region and the somewhat lighter sides. The foremost side-patch over the eye has a more indistinct posterior boundary. Compared with the foregoing cmbryo. the pigmentation in the axil beneath the pectorals has advanced, and on the abdominal surfice, the boundary approaches the median line in such a way that the hinder white sirle-patch almost seems cut off in front, thus giving this part. When riewel from the abdominal surface, the appearance of a three-lobed leaf with a narrow stalk in front. 


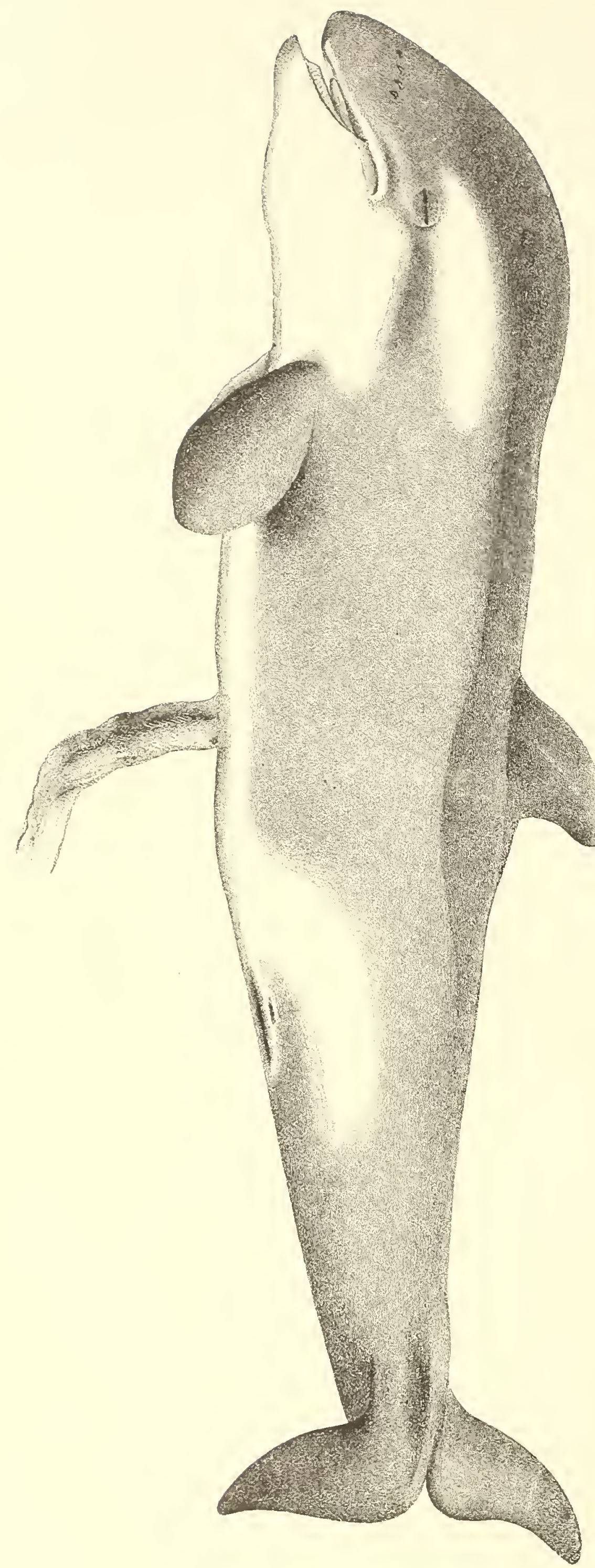

Iig. 3. Orca gladiator; a female fotus 875 millim. long.
On the front of the female genitalia, the labia majora exhibit a brownish patch. The white colour on the inferior surface of the tail fin is more leveloped and extends farther than in the previously described embryos. It may be noticed with regard to the character of the colour in these half-dereloped fotnses (of which the Bergen Museum contains several), that the colour is almost blue-black with changes to brownish and grey tints, while the unpigmented skin-colour is yellowish with a tinge of red. The isthmus between the lind lobe of the white trefoil and the white colour of the abdomen is very narrow in places. The umbilical cord is also darlily pigmented, the pigment beginning at a distance of $1 / 2$ centim. from the insertion.

In foetuses of this stage of developement, the incipient dental series appears like a crenulated fillet, becoming narrower in front and belind: 10 prominences may be counted on each side. The number of the foctal hairs varies between $t$ and 6 . The eye region generally forms a slight convexity.

Two larger embryos, respectively 1.870 metres and 2.080 metres in lengtl were acquired by the Bergen IIuseum in Nor. 1887 from a catch on Bildoen. The curator, Grieg, has furnished measurements of them (cf. Annual Report of the Bergen Museum, No. 4, 1889). These embryos I classify as "almost full-grown."

IV. A young Orca. In Jan. 1891, the Christiania University Museum obtained a young female Orca, 2.51 metres in length, of which an illustration will be found on Pl. T, fig. 2. The skin has been stuffed and placed in the Zoological Huseum, the skeleton in the Zootomic Collection. The dimensions of the animal were as follows: -

Total length, in a straight line from the point of the snout to the tail cleft. . . . . . . . . 2.51 metres Length from the point of the snout to the extreme

point of the tail lobe. . . . . . . 2.54" Circumference belind the pectorals . . . . 1.21 " Lengtl of pectorals . . . . . . . . . 0.28 " Breadth of do. . . . . . . . . . . 0.16 " Height of dorsal fin . . . . . . . . . 0.19 " Breadtl of do. at base . . . . . 0.25 " Breadth of tail fin . . . . . . . . . 0.55 .

On considering the uninjured animal, one is struck by the elegant form of the body, which still seems somewhat more slender than in the full-grown animal. The snout rather calls to mind the dolphin's "beak", for in the line of contour of the upper jaw, there is a slight concavity a little above the point of the snout (see Pl. V, fig. 2).

The pectorals are of the characteristic leaf-like form; their length amounts to nearly $1 / 9$ of the length of the body (in the older female, they amount to $1 / 8$, in the older male, from $1 / 6$ to $1 / 5$. according to Lilljeborg, lit. 72 ). 
The greatest circumference is between the pectorals and the dorsal fin, and amounts to barely half the length of the body (in the full-grown animal to more than half).

The dorsal fin, which is slightly convex in front and rery concave at the back, is situated almost in the middle of the body. though reaching a little orer on to its anterior half, as in the female figured by Lütken (K. Danske Tid. Selsk. Skr. 6 R. m. n. Afd. IT, 6, pl. I). The dorsal fin amounts to rather less than $1 / 13$ of the length of the trunk (in the young female $1 / 12$, in the older female $1 / 8$, in the older male from $1 / 6$ to $1 / 5$ ).

The breadth of the tail fin is equal to $1 / 41 / 2$ of the length of the trunk (in the younger animals from $1 / 5$ to $1 / 4$, and in the older ones from $1 / 4$ to $1 / 3$, according to Lilljeborg, l. c.)

These proportions of the pectorals and other fins in relation to the length of the trunk confirm most fully the general rule that all limbs and fins (caudal and dorsal fins) become longer with age (cf. Luitken, l. c.).

The distribution of colour in this young one, agrees in all points with that commonly known in older specimens.

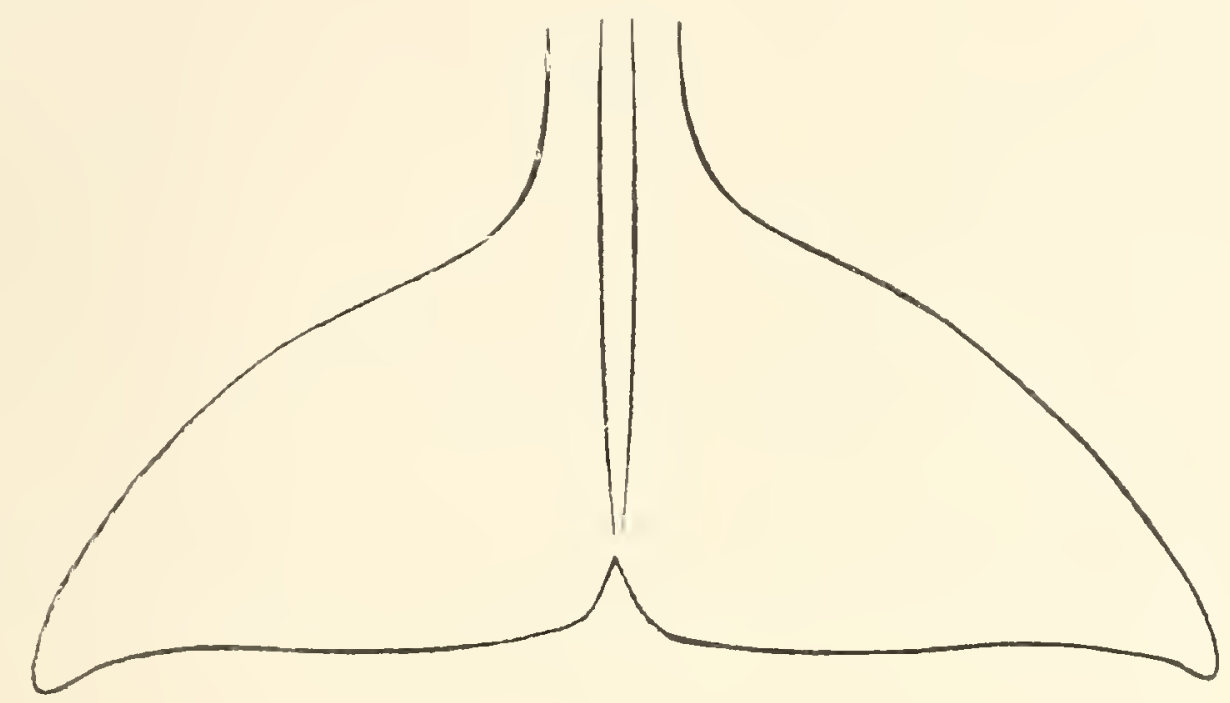

Fig. 4.

Outline of the tailfin of the 875 millim. long female foetus of orca gladiator, seen from above.

The dark colour of the body is a deep blue-black, and the light colour beneath. cream-white (Pl. $\mathrm{T}$, fig. 2). There is no blue or violet patch beside the dorsal fin. Passing orer a few details at the junction of the black and the cream-white colours between the peciorals and the angle of the moutl, it may be observer that the light colour is here found on the lower border of the upper jaw, a circumstance which Lilljehorg states to be a rule, but which does not appear in the female figured by Liitken.

General remarks. The generic and specific characters are perhaps developed earlier in the Orea than in many other species of Odontoceti. It is remarkable that in a fortus that is hardly $1 / 5$ of the length of the newly-born animal, the generic characters are so distinct. that the fortus can without difficulty be distinguished from other Odontoceti. It is therefore not surprising that Eschricht in his time, found that embryos of whales might be employed as an important aid in studying the general form of the full-grown animal. When the fortus has attained to half its full size (i. e. length), the specific characters are distinctly risible, even in the distribution of colour, though of course there is still a want of distinctness in the lines of demarcation and the more delicate shades of colour. There may possibly, too, be changes in this after birtli. But the various segments of the body are found with their ordinary conditions. In thus contemplating the newly-born animal, one is involuntarily struck by the thought, that when Nature sows seed most sparingly for the maintenance of the species. she compensates for it by making each seed perfect! Te thus find that a newly-born Cetacean is one of the most fully dereloped newly-born animals in the whole class of Mammals. 

III.

GUSTAV GULDBERG

CONTRIBUTIONS TO THE KNOWLEDGE OF THE

FEETAL MEMBRANES IN ODONTOCETI.

PI. VI-VII. 



\section{Contributions to the Knowledge of the Developement of the Fotal Membranes in Odontoceti.}

Plates VI and VII.

I 11 the preceding literary survey, the most important works in which the subject of the foetal membranes in Cetacea was treated, hare been mentioned. I will now shortly refer to these.

Eschricht (39) in 1837, describes the surfaces of the chorion as very much wrinkled, and covered with villi $1 / 2$ line distant from one another, and states that the villi had a stalk, and that the free end expanded in the form of a globe, like the head of a caulitlower. In the depressions between the rngie, there were small villi. A beautiful capillary net-work was noticed in the crowns of the villi. They correspond to the depressions in the mucous membrane of the uterus, which is very vascular. Eschricht also describes numerous ramified uterine glands, and believes that their secretion is taken up through the reins into the villi. - Owen (Anat. of Vertebrates, vol. III, p. 732) remarks that the fotal membranes extend into both the horns of the uterus. After having mentioned the villosity of the chorion, the uterine mucons membrane, and the smooth poles of the chorion, he compares the diffused placenta to a broad "placenta zonata".

It is, howerel, as alveady stated, to Sir. William Tul'ner's (43) famous work that we owe most thanks for the linct that the Cetacean's placenta is no longer so unfamilial a subject as it was a generation ago. In his examination of the "Blue Rorqual" (Balanoptera sibbaldii. Gray) stranded at Longniddry in 1869, Turner describes the folds and wrinkles of the chorion, the rillous character of its surface, and the presence of a well-defined spot which is without rilli. In 1871 appeared his important treatise on the uterus and the foetal membranes in Orca gladiator. Lacépède. He there gives an account of the structure of the uterus, the fotal membranes, the position of the foetus, and makes a general comparison hetween the formation of the placenta in Cetacea. and the diffuse placenta of other Mammals (Mare, Sow). The nterine uncons membrane is divided into a cryptal layer and a glandular layer. of which the former is the more highly raseularised. The chorion is diffusely beset with villi, but presents 3 bare spots, viz. 2 small ones, one at each pole, and 1 larger one corresponding to the os uteri internum; the patches that are bare of villi correspond to the uterine cavity's natural openings. - The scattered villi of the chorion are distinctly visible to the naked eye, but their form and arrangement, on heing slightly mignified, present many variations, as they stand now in parallel rows, now in little groups, and again more dispersed, composed as a rule of several smaller, secondary villi. As regards their histological structure, Turner found that the villi consisted of a fine connective tissue, in which were imbedded numerous round and spindle-shaped bodies; but on the other hand, he found no epithelial covering, supposing, very rightly, that the epithelium cells had fallen off during treatment. 'The chorion consisted of 2 layers, an onter layer with rilli, and an imner thim, transparent layer, between which the ressels were divided. The capillary net-work of the rilli passed minterruptedly into these subchorionic ressels, which then becanıe the roots of the mmbilical reins. The intravillous capillary plexus lay. in relation to the capillary system, in the walls of the uterine crypts. while the subchorionic layer was situated beneath the plane formed by the surface of the general uterine mucons membrane. The umbilical cord consisted of 2 arteries and 2 reins and the urachus. The amnion formed a continuous h:ig from one horn of the chorion to the other. but did not extend quite to the poles, though farthest in the left horn which contained the fortus. Its surface was beset with small yellowish brown bodies.

That portion of the ammion at the back of the foetus was attached to the inside of the chorion by a rery fine tibrous tissue, but at the attachment of the allantois to the chorion, i. e. that part corresponding to the rentral surface of the firtus, the amnion passed on the outside of the cylindrical horn of the allantois. and was accompanied by this membrane to the 
funiculus umbilicalis. The amnion was of far greater extent than the allantois, the latter reaching not nearly so far out towards the poles. The allantois occupies the concave portion of the horn of the uterus and is smaller than the amnion. - Turner deduces rery important physiological conclusions from his comparative examination of the Orca's fotal membranes with the Ungulate forms of diffuse placenta. Thus he says (p. 501) "I am not disposed to consider that the utricular glands cease to perform their functions at an early period of embryo-life. In this Orca, although the fœtus has reached an advanced stage of developement, the vascularity of the glands, their epithelial contents, even the presence of plugs of epithelium or inspissated secrction projecting through their orifices, all gave one the impression of structures in a state of active employment. If this be the case, then the secretion would be poured out into the crypts, and brought in contact with the villi of the chorion." - In an able treatise (in Proc. Roy. Soc. Edin. 1875-76), in which the same author describes the foetal membranes in the Narwhal (Monodon monoceros), the discoveries and conclusions previously made are confirmed. Concerning the chorion of quite a small Narwhal fotus (31/4 inches long) he remarks, that it "was not villous, but traversed by faint ridges, which without doubt fitted into the shallow furrows of the mucosa".

An interesting contribution to the knowledge of the foetus and the foetal membranes is moreover made by Andersson (45), who, besides the external form, anatomy and habits of Orcella and Platanista, also describes their gravid uterus, fœtal membranes and embryos. He draws attention to the fact that there are several bare spots on the chorion fretalis in Platanista, where there are no villi. The layer described (p. 491) as mcmbrana intermedia, betwcen the chorion and the amnion, is probably the mesenchyme, which I have described below, as it attaches itself to the more differentiated thin layers of connective tissue. upon which the chorionic epithelium lies. The position of the fretus in the casc described by Andersson, was also in the left horn of the uterus, only with the snout up towards the end of the horn. In other respects, Andersson's description agrces with the circumstances previously described by Turner as found in the Orca, so that the fortal membranes in these tropical species of Dolphin do not materially differ from the others.

Further contributions are madc by Beauregard and Boulart (47), who describe the mucous membrane of the gravid uterus, and the foetal membranes of Balænoptera Sibbaldii. They for the most part corroborate what Turner has already shown. Chabry and Boulart (48) describe a fous of Delphinus delphis, L. with the foetal membranes, and its position in the uterus, a description further corroborating previous discoveries. Hermann Klaatsch (55) describes at some length the futal membranes and their histology, (more particularly the structure of the umbilical corrl), of a fotus of Phocrena communis, Less.. 60 centim. in length, to which are added remarks on the microscopical structure of the uterine mucous membrane and the genitalia in the mother animal, and on the fotal milk-glands. Hc points out among other things, the persistency of the ductus omphalomesentericus in the unbilical cord, and that in the Phocæna there is only one bare spot on the chorion, namely, at the left polc of the ovum.

From the facts alrearly given, it is clear that as regards their foetal membranes, the Cetaceans must be placed in the group, which embraces mammals with a diffuse placenta, and therefore approximate certain forms of Ungulates. Balfour, (49), however (Traité d'Embryologie et d'Organographie Comparées, traduit par Robin et Mocquard, Paris, 1885; vol. II), makes the very plausible remark: "Les Cétacés diffèrcnt considérablement des Ongulćs par la dimension de l'amnios et les faibles dinensions du sac allantoïdien persistant," - with which Max V eber (54) also seems to agree, as he, with full justification. sars: "Auf die Placenta allein hin die Cetacen zu Ungulaten zu machen, wäre gewiss unrichtig. Doch ist sie gewiss cin Zeichen ursprünglicher Verwandtschaft." To this he further adds, — and I am also of his opinion, - "dass die diffuse Placenta ciue schr primitive Form ist, und insofern gut übereinstimmt mit dem primitiven Verhalten anderer Organe, die Cetaceen... zu einem generalisirten, collectiven Typus machen, der nur nach einzelnen Richtungen hier in hohen Masse specialisiert ist."

After these remarks and quotations from the most important litcrature on this subject, I shall pass on to relate the varions facts I have elucidated from the material at my disposal. The figures illustrative of these will be found on P'. VI and VII. It may be mentioned that Dr. F. Nansen drew the figs. 2 and 3 on Pl. YI. For the interpretations put upon the different facts given in the following, [ (Guldberg) an alone responsible.

\section{Lagenorhynchus acutus, Gray.}

In the great take in November 1885 on Torskizen. whercby the Bergen Museun acquired a unique collection of Lagcnorhynchus acutus embryos, there was also taken out of a female animal an entire small ovum, in which the smallest of the embrros described above, viz. 8 millim. in length, was found. This ovum will now be morc particularly described.

As fig. 1. Pl. VI shows, the ovum was oval, about $75 \mathrm{millim}$. in length in the hardened condition, and cxhibited a perfectly smooth surface without rilli, a circumstance which agrees with Turner's description of the fotal membranes in the sniall Narwhals fietus (44). A few furrows running in different directions may perhaps be ascribed to the hardening process; but in certain places it shows larger natural folds and an incipient villus formation. 
The external form of the ovum is an elongated oval with a slight constriction in one half, which imperfectly divides it into one large oval portion of $2 / 3$ and one smaller more spherical portion of $1 / 3$ (see fig. 1, PI. VI).

Some darker lines and points which shine through from within, and form dotted rows or small stars, impart a certain appearance of shading to the surface, indicating the finer distribution of ressels in the chorion. The course of two or three larger veins is visible on one side of the ovum in the form of a black streak ending in the larger oval part of the orum with a conical, black prominence: a corresponding smaller one is seen in the smaller third of the ovum.

On cutting open the chorion and spreading it out, there is found to be a large space between the wide chorion and the littlc ammiotic bag. (See fig. 2, Pl. VI). This space is filled with an exceedingly aqucous, embryonal mesenchyme, which when magnified has the appearance of a partially transparent, greyish white, woolly mass, enveloping the amnion, in the hardened specimen, in closer layers, lining the inside of the chorion, and filling up the large intermediate space, the subchorionic space. In the soft mesenchyme of this space, the long, band-like allantois lies extended (Pl. VI, figs. 2 and 3, all), the shape of its broad end, which covers the amnion recalling that of a myrtle leaf. The allantois cxtends parallel with a thick rascular cord, of which the bud-like, thickened ends can already be seen cxternally on the chorion, as mentioned above. While the broad, leaf-shaped portion of the allantois (Pl. VI, fig. 3. All) covers the amniotic bag, there are visible, close to the middle of the allantois, 4 resicle-like formations, over which it passes. These transparent vesicles lie close to the amniotic bag, and are so arranged that 3 are situated on the one side, and one projects on the other side (fig. 3). As figs. 2 and 3, Pl. VI, show, the broad end of the allantois belongs to the larger dilated end of the orum in which the embryo lies, while the narrow end which is rounded, occupies part of the smaller spherical end of the orum. The external appearance of the allantois is speckled, a circumstance which arises from the unequal degree of transparency. Owing to the preserving of the specimen, grayish, nore or less transparent masses of fibrine are found precipitated upon the allantois. In fig. 3 the allantois looks much narrower than it really is, because, the iumen having collapsed, it lies in folds. - From alont the middle, perhaps'a little nearer to its broader end, goes a transverse band, which passes to the narrow, nearer end of the amniotic bag. 'This connection of the allantois cannot, however; without the aid of magnifiers, be clearly distinguished from the abundant precipitated fibrine mass.

On raising the broad end of the allantois, the triangular amniotic bag, between 10 and 11 millim. long, could be seen, and through it, the ontline of the embryo was discernible (fig. 4).

The amniotic bag (Pl. VI, fig. 4, am) is of a rounded triangular shape, and envelopes very closely the little fortus. The one pointed end turns towards the more isolated vesicle (fig. $4 \mathrm{v}$. u.), while the adjacent high edge of the bag is situated close to the nearest of the row of 3 vesicles. The wall of the amniotic bag is very transparent, and shows small sciltcred, vascular ramifications.

The resicle-like formations (Pl. VI, figs. 3 and 4) are of a varied nature. The three vesicles in a row on one side of the allantois (fig. 4, b), the middle one of which lies above the other two, form enlargements full of fluid, not apparently communicating with one another, but closed, and adhering firmly to the chorion, one of them being probably in comnection with the amnion.

The more isolated resicle (fig. 4, v. u.) loosened itself from its surroundings during manipulation. It measured $51 / 2$ and 6 millini. in diameter, was of an oval spheroid shape, and showed on its surface some sigmoid, grayish brown protubrances (Pl. VI, fig. 6). The space in which the vesicle lay proved itself to be in close connection with that place in the amniotic bag whence the umbilical cord of not more than 1 or 2 millim. in length protruded. I might therefore conclude that this was the resicula umbilicalis, as it could not possibly, per exclusionem, be any other formation: otherwise it would be abnormal.

T'uner (43) makes the following statement about the umbilical vesicle: "The umbilical vesicle, again, disappears in Orea some timc before birth, as in the mare, pig and ruminants, and does not persist in the form of a considerable sac as in carnivora, rodents, bats and insectirora; or as a rudiment, as is sometimes seen in the human subject." The ductus omplialomesentericus (Dottergang), of which the persistence in the Phocæna until a short time before birth is pointed out by Klatsch (55), is delincater in transverse sections in various parts of the umbilical cord; but Klaatsch affirms witl regarl to the Vesicula umbilicalis: "Ton der Dotterblase habe ich bei meinen Objecten nichts gefunden."

How far there may, in the above case of Lagenorhynchus acutus; actually be a question of a resicula unbilicalis, I am not prepared to say with perfect certainty, for, as we shall presently see, there is not a perfect guaranter for it histologically, though the probability is in its farour. In this case. however, I consider it to be developed to an almormal extent; for, as we shall presently see in the case of the Phocana, it is clearly in a rery early stage of developement.

The histological facts about the foetal membranes in question are as follows:

The structure of the fotal chorion (Pl. TII, fig. 1). The externally smooth chorion is formed peripherally of a layer of cubical epithelium (Pl. TII, fig. 1. E) for the most part simple, but in a few places a double stratum, and generally furnished with large nuclei. The epithelium rests upon a thin membrane of connective tissue (fig. 1, B) composed of two strata of elongated, spindle-shaped and star-like cells with rery few intercellular fibres. Beneath this lighly 
cellular tissue is a jelly-like mesenchyme with few cells (fig. I. II) strongly recalling the mesenchyme in Cœlenterata. The peripheral part of the mesenchyme is distinguished by its sparse, wary fibres (fig. 1, M), which run in one special direction, while the scattered cells are of the nature of large wandering cells, with here and there an indication of a star-like shape, or with pseudopod-like off-shoots. The transverse section of capillary ressels, with here and there a larger ressel, is also found. - In the deeper-lying parts, the coloured specimens present a more granular appearance, and small, oblong racuoles (fig. $1 \mathrm{Yc}$ ) while the fibrous element is less prominent.

Seen from the surface, the chorion exhibits a large-meshed network of ressels (Pl. VI, fig. 5) under the epithelium in the peripheral layer of connective tissue; in section, these appear only as scattered ressels forming a large-meshed capillary network.

The structure of the amnion exhibits a simple, flattened epithelium, with a thin embryonic connective tissue outside, in which small scattered ressels and capillaries are seen. The amnion is divided by a distinct fissure from the surrounding mesenchyme.

The structure of the allantois (Pl. VII. fig. 2). A piece of the band-like allantois was cut off, coloured and microtomised. The transrerse sections show an inner, fissure-like cavity, the carity of the allantoic bag (fig. 2, al). This is lined inside with a simple stratum of flattened epithelium (fig. 2, a e), which rests upon a peculiarly-formed foundation of connectire tissue (fig. 2, a b). On first glancing at the carmine-coloured specimens, one is reminded of prismatic or high cylinder epithelial cells. The flattened epithelium is in most places loosened from the connective tissue, and lies in elongated, coherent strata in the lumen of the allantoic sac, in some places rolled together into masses, and in others lying close up to the connective tissue. This tissue is comparatively thick, and is distinguished by a closer intercellular substance that is more readily coloured in carmine, and which lies next the epithelium. It is of the nature of an embryonic mucous tissue, with variously shaped cells, now spindle-shaped, now polygonal, and its off-shoots lying in a ground substance which readily becomes coloured. The peripheral cellular layer consists of elongated, mostly spindle-shaped cells (fig. 2, a d). The intercellular substance is homogeneous, as it is only in the peripheral layer that there are here and there fibres of comnective tissue. In a few places, there are littie clusters of proliferative embryonic tissue cells. Klatsch's description of high cylinder cells in the allantois in Plocæna, I am quite unable to substantiate in Lagenorhynchus acutns.

The allantoic lumen is everywhere very small. in many places only like a narrow fissure: which indicates that there must have been only a rery little allantoic fluid.

The supposed umbilical vesicle (Pl. VI, fig. 6) was coloured and microtomised. The sections showed that the chief bulk of the walls consisted of embryonal connective tissue, while a simple, flattened epithetium was with difficulty seen upon the inside. The thickenings in the wall. which were easily seen with the naked eye. consisted, histologically; for the most part of embryonic connective tissue, which seemed to be in a rery proliferative condition (Pl. VII, fig. 4) — little intercellular substance, and many cells which were very chromophilous. In one of the thickenings of the wall are constantly seen one large, or 2, sometimes 3 smaller lumina (fig, $t, 0 . m$ ). lined with a beautiful cylindrical epithelium; in the large lumen this is cubical (Pl. III, fig. t. ep), in the small ones high cylindrical. These epithelium-lined lumina greatly resemble a large glandular duct. If my explanation of the hollow vesicle is correct, I must consider the large lumen as belonging to the ductus omplialo-mesentericus, and the small lumina as belonging to abnormally developed ramifications of the same. There are, moreorer. in many places on the walls of the vesicle, large and small thickenings. of which the many chromophilous, closelying cells point to a probably abnormally energetic growth in this embryonal organ. In a few sections, where the thickening includes a longer portion of the wall, may be seen 2 close-lying vascular lumina and 2 epithelium-lined lumina.

On making a section through the entire amniotic bag with the adjacent three resicle-like formations and the allantois, my supposition that the resicles lying side by side must be enlargements of the amniotic bag, was strengthened, though not in its entirety; for I could not with certainty prove the presence of epithelium on the inside. Only one of them seemed to consist of a thin epithelium, and must therefore belong to the amnion. The two other resicles, however, I consider as abnormally-shaped enlargements in the mesenchyme lying nearest to the outside of the amnion. None of these resicle formations were to be found in the foetal membranes of the small Phocena embryo subsequently examined, nor had the welldeveloped ammion in that specimen a small, shrivelled lumen. but on the contrary, a large one. Both ora, howerer, agree in the circumstance that the allantois is well dereloped at a very early stage, and is of comparatively large dimensions.

Upon the whole, the impression obtained from this orum containing the 8 millim. long embryo, was that of an abnormal derelopement, abnormal at any rate in certain directions, although in other respects it is normal.

Recapitulation. The $i_{5}$ millim. long, oral orum, containing the $S$ millim. long embryo, presents a smooth chorion with sereral longitudinal folds, and only indications of incipient rilli in a few places. The subchorionic space is probably abnormally large, being filled with a richly succulent mesenchyme. The ribbon-like allantois, from 35 to 40 millim. in length. has a broad, leaf-like dilated end, where the embryo lies, and shows a simple, flattened epithelium, which lines the lumen. The amniotic bag is 10 millim. in length, triangular in form - probably oval in the fresh specimen - 
closely enreloping the little embryo, the intermediate space between the surface of the embryo and the amniotic bag being very small. Moreover the amnion, which consists of an inner stratum of flattened epithelium, and an external thin layer of connective tissue, seems in a great measure to be separated from the surrounding subchorionic mesencliyme by a fissure. The vesicle-like dilatations of which the further connections and meaning could not with certainty be explained, seem to me to be abnormal formations, the supposed umbilical resicle being also, in all probability; abnormally developed, and by evident thickenings of the walls, proves itself to be in a progressive condition.

It seems not improbable that this instance rcpresents the commencement of a condition which in man is known by the name of resicular mola.

Fotus :. On considering the fotal membranes of the 30 millim. long foetus, we are met by a more advanced developement. The fotus is figured lying in its amniotic bag (Pl. VI, fig. 7).

The amnion still envelopes the foetus somewhat closely, although its cavity is relatively much larger here than in the 8 millim. long fotus. In the region surrounding the point of attachment of the umbilical cord, several fine vessels are observable, forming a large-meshed network on the amniotic bag, especially on that part which answers to the embryo's rentral surface. On examining it microscopically, there is found on the inside towards the lumen of the bag, the usual epithelium, which is flattened and simple; outside this lies a thin stratum of connective tissue (parietal mesoblast), in which fine rcssels spread, as previously stated, from the insertion of the amnion upon the umbilical cord, forming a large-meshed scanty vascular net-work. Inside the fine vessels, there were plainly seen nucleated coloured blood corpuscles, and in a few places beautiful illustrations of the formation of new blood-ressels.

The unbilical cord is 8 or 10 millim. in length and about 4 millim. in diameter immediately below the place of insertion. It runs rentrally towards the head for a little way, and is resolved into its elements after a short course, the relatively large vascular stems heing divided in the chorion.

The vcry capacious chorion presents an elongated shape corresponding to the uterine cavity; but of which the details were not distinguishable, on account of the imperfection of the preparation. - The surface of the chorion in the specimen is very wrinkled, the larger folds following the long axis. By dilating the chorion, the folds do not disappear, but, on the contrary, the "nodular" appearance becomes very distinct; for there arc a number of small, scattered, wart-like promincnces on the surface, which are the chorionic villi, but they are very short and widely separated.

Even with only a comparatively good magnifying power, on viewing the chorion from the surface, a large-meshed net-work of rather thicker vessels is observable. among which is spread a fine-meshed capillary network.; On a microscopical ex:mination of the chorion's free surface, the epithelium presents a beautiful mosaic appearance. On investigation of the serial sections, one notices on the extreme outside, a layer of cubical epithelium, which has, in many places, a cylinder form, and in others approaches stratified epithelium. The substratum of connective tissue consists; beneath the epithelium, of spindleshaped (rarcly star-shaped) cells in one or two dense strata, and then of mesenchyme with sparse cells. It is also obserrable here, that the widely-extended sub-chorionic cœlom, which has, moreover, become much more restricted by the anmion and allantois, is partly filled with a serous, albuminous liquid, from which, by hardening, various probably albuminoid substances have been precipitated. This, therefore, strongly resembles that in the previously described stage. As for the vessels, the serial sections show that the large vascular stems lie imbedded more or less deeply in mucous membrane, while the capillaries lie close to the subepithelial stratum of connective tissue, and often just below the epithelium, so that only the simple epithelium and the vascular wall itself scparates the fotal blood from the uterine wall. In those places where the surface of the chorion forms large or small swellings, a very rich capillary net-work may often be observed.

The allantois forms a large, wide bag, which, in the well-preserved portions of the membrane, lies close to the chorion, from which it is separated by a layer of embryonic tissue, as before mentioned. Its relation to the ammion is peculiar. At the place whence the ressels of the umbilical cord begin to spread themselves out into the subchorionic tissue between the chorion and the allantoic bag, the allantois lies close to the amnion, and adheres firmly to it, its thin wall sceming almost to insert itself on the amnion over an extent corresponding to the ventral surface of the embryo (cf. Pl. VI. fig. 7, dotted line). - The allantoic bag itself, as a thin membrane, can easily be separated from the chorion, and from the subchorionic connective tissuc.

Microscopically it proves to consist of a simple, very flat, stratified epithelium on the side turned towards the allantoic cavity (entoderm epithelium), and nutside this, of connective tissue with scattered, spindle-shaped and star-like cells, with smaller vessels imbedded (visceral mesoblast).

It also appcars in this specimen, that the allantois is of larger dimensions than the amnion. The histological conditions agree with those preriously described. 
No vesicula umbilicalis was yisible to the naked eye. There is every reason to believe that this formation becomes atrophied very early, as previous authors have supposed.

Foetus 3. In the 53 millin. long fœetus, which is figured on Pl. VI, fig. 8, lying in the amniotic bag, and with a portion of the foetal membranes attached to it, we find in these last only slight changes from the stadium immediately preceding.

The amnion forms a much wider bag. Its surface is especially remarkable for the large-meshed net-work formed by numerous vessels of coarse and fine calibre, which are found on that portion of the bag answering to the embryo's ventral side. The conical, tapering umbilical cord describes a curve, concave to the embryo's ventral side, and extends backwards towards the tail, passing on the right side of this, in order to attach itself, and send out vessels. The cavity of the ammion here extends a little way down, and forms an enlargement, its wall attaching itself to the place of insertion of the umbilical cord. On a microscopical examination, it appears that the entire wall of the amnion consists of a flattened cubical epitlelium, with an extremcly thin layer of vascular tissue outside it.

The allantois, in this as in the preceding stage, adheres for some way to the amnion, in such a manner that the starting point is where the rmbilical cord begins to dilate. When the allantoic bag is opened and the anniotic bag filled, the latter pushes a little invagination in the former. The thin transparent allantoic membrane lies very close to the chorion, but is easily and without tearing it, loosened from it. A microscopical examination of the surface shows a polygonal epithelium with an equally thick connective tissue outside. In transverse sections, the allantoic wall is seen to consist of a simple stratum of epithelium resting upon a mucous tissue of sparse, partially spindle-shaped cells (Pl. VII, fig. 3, All). The intercelhular substance of the mucous tissue takes a darker colour from carmine than the thin mesenchyme lying between the chorion and the allantois.

In the specimen examined, the greater part of the chorion belonging to the corpus uteri, and one of the horns is in good condition. The surface of the chorion is exceedingly wrinkled and folded, and, on being magnified, proves to be beset with low, round, wart-like excrescences, which become especially distinct on stretohing the chorion out over a white ground or in front of a light. These wart-like villi are of greater extent, and therefore appear denser here than in the stadium previously described. The larger folds are generally longitudinal. The outermost third of the chorion's cornua is free from villi, and shows fewer folds, being in many places almost smooth. The verrucose villi also appear more scattered farther out over the end of the lorn, and more numerous nearer in towards the part. corresponding to the corpus uteri. In section, the usual epithelium of the chorion (Pl. VII. fig. 3, E) is observable; it is simple and cubical as in the preceding stages. In the depressions between the villi, it is cylindrical. The subepithelial tissue is much more rich in cells in the villi than elsewhere, while the space between the chorion and the comparatively adjacent allantoic bag is filled with a serum-impregnated mesenclyme, with few cells (Pl. VII, fig. 3, M).

The ressels have become far more numerous in this stage, and fine capillaries lie close in under the epithelium.

The villi are larger and have a narrower collum, with expanded peripheral free ends. There are numerous subepithelial ressels.

The fatal membranes in the more advanced embryos show principally a further growtl of villi. The chorion in the 92 millim. long embryo had thus a mass of folds, both large and small, rumning in different directions. The wart-like villi were distinctly seen at this stage of developement as prominences from 0.5 to 1.5 millim. broad, in some places very dense, in others more scattered. As previously stated in the less-developed stages, the wart-like villi decrease in number towards the narrower peripheral portions of the chorisnic bag.

Recapitulation. It must be noted as a peculiarity, that only when the ovum has attained to a considerable size and the embryo's length may be measured by centimetres, does the surface of the chorion begin to assume a villous character. The amnion and the allantois are at first of small dimensions, the allantois considerably exceeding the amnion in length. These relations, howerer, soon begin to be equalized and then gradually reversed, so that the amnion is considerably longer than the allantois, the lattcr however, during the entire embryo life, occupying a considerable space. The further developement of the chorion consists chiefly in a growtl of villi with an increasing formation of capillary net-work. When the fœetus has attained to about $1 / 10$ of the length of the animal at birth, the villi appear to have assumed their definite shape. In the mean time, more and more villi gradually make their appearance on the cornua of the chorion, almost up to their ends. It is only in an early stage that there is a distribution of villi, corresponding to the "placenta zonata". The chorion, liowever, preserves its primitive, "diffuse placenta" type until the end of the period of gestation, so that there is no question of a placenta in its true sense. 
The fact that the chorion retains a smooth surface for a comparatively long time, seems to point decidedly to a condition found in Ungulata, and also presupposed here by many writers, viz. that the uterine glands are organs for the secretion of nutriment. There is much to be said in favour of the theory that this is a primary or original function of the uterine mucous membrane, and in that case this organ in the Cetacea has preserved its primitive function more fully than in most other Mammals.

\section{Orea gladiatol, Lacépède.}

In the case of two or three of the previously described Grampus foetuses, especially in the 40 centim. long fœetus, a large portion of the fœtal membranes was found adhering to them. Although these can hardly be said to present anything new, they have their peculiar interest, and for that reason, I append some observations which may supplement the general knowledge of the Cetacean's foetal membranes to which, thanks to the investigations of Turner and other naturalists in the last few decades, we have attained.

The umbilical cord in the 40 centim. long Orca fotus measured 31 centim. in length from its insertion to the point of dirision. Its thickness was about 1 centim. near the insertion. It showed only 2 or 3 twists, and was beset with a number of club-like nodules, some liurge, others small, and all upon a narrow base.

Its insertion, similar" to an "insertio relamentosa", is rery characteristic. The umbilical vessels diverge in two principal directions, corresponding to the horns of the uterine cavity. After their divergence from the ends of the umbilical cord, the ressels run between the amnion and the wall of the allantois, to the chorion (fotalis) where division and breaking up into the rascular network commences (see Pl. VII, fig. 5, v).

The amniotic bag in the present specimen presents conditions characteristic of the Cetacea. Just as the surface of the umbilical cord is furnished with a number of scattered elevations, similar excrescences are found upon the inside of the walls of the amnion, forming grains the size of a poppy-seed, - the amniotic bodies. They are scattered abont irregularly at a distance of from 3 to 11 or 12 millim. from one another, and are for the most part only found on that part of the wall. whieh is joined to the allantois, and out into the continuation of the horns. No fusion of the amnion and allantois walls has taken place, as they can easily, with a little care, be separated by means of two tweezers (Pl. VII, fig. 5, m s). While the ammiotic bag in one horn extends rather far ont - its extent could not be ascertained on account of the defectiveness of the specimen - in the other horn it forms only a small enlargement, which extends into the beginning of the horn.

The allantoic bag. at this stage of developement, is of greater extent than the amnion (Pl. VII, fig, 5 all), which, acording to 'Turner, is not the case at a more advanced stage. The allantoic cavity can be traced far out into the two linns. - the outermost part was unfortunately cut away - and its walls form a tolerably firm membrane which lines a large portion of the chorion, and lies, as before stater, close to the ammiotic bag for some distance. On looking at the transverse section of the one horn (Pl. VII, fig. 5) into which the cavities of both bags extend, the much folded chorion with its rilli (ibid. ch.) is plainly seen, als also the two lumina of the allantois (ibid. all), and the amnion (ibid. am), of wlich the walls are thin membranes. Two or three larger vessels lie in the corner between the amnion and the allantois (ibid. r.)

Microscopically. the allantois shows the usual much flattened epithelium, and a thin tissue with an intercellular sulstance only slightly susceptible to colour (carmine).

The chorion presents the characteristic longitudinal folds, with numerous smaller folds in different directions. It is densely beset with wart-like excrescences or rilli, which impart to it its peculiar appearance. It is somewhat thin in the part corresponding to the corpus uteri, a little thicker out towards the horns.

On microscopical examination, the foremost villous excrescences present a characteristic appearance. They form Pl. VII, fig. 6, ve) large and small swellings which usually have a narrow base and a broader end. The epithelium is generally low cylindric or columnas (fig. 6, e) and in the depressions, higher columnar. The connective tissue on which the epithelium rests is rery rich in cells, some of them being wandering cells, or at any rate, are round and do not appear to be stationary. It is characteristic that between the chorionic and the allantoic connective tissue, or the ammion, there lies a thin, homogeneous, oniy slightly cellular stratum, with only a few round cells here and there (Pl. VII, fig. 6, m), and which is often of the same nature as the homogeneous mesenchyme which was found in such quantities in the smallest ovum of Lagenorhyuchus acutus (see p. 11 and pp. 53 and 54). This mesenchyme tissue is probably always present in the subchorionic space. It was even found in the basal portion of the larger villous excrescences. - The ressels, especially the larger ones, do 
not appear to be especially numerous. The larger vascular lumina lie under the denser stratum of the connective tissue (fig. 6, k', k", the great lumina) the capillaries are found close under the epithelial cells, and are in many places numerous (Pl. VII, fig. 6, k).

For the sake of comparison, I also examined the chorion fotalis of a $5^{1 / 2}$ months gravid mare, where, as is wellknown, diffuse placentation occurs, and with which the Cetacean placentation has so often been compared. The chorionic villi were shorter here and seemed to me to have a somewhat different character, although the ground type is the same. The chorionic and subchorionic tissues were much more differentiated, being every where bundles of connective tissue: the larger vessels were present in greater numbers. 'The chorionic villi had a flattened, simple, stratified epithelium in their more peripheral ends. No mesenchyme-like, subchorionic tissue was to be found, as in the Delphinidæ.

In the 875 millim. long Orca foetus, the umbilical cord measured 450 millim. in length, and about 2 centim. in thickness in the region a little below the insertion. A little farther down, it becomes thicker and exhibits pigmentation in the first 4 or 5 centim. from the insertion. It is beset with the usual small excrescences, which are also found on the inside of the amnion, now more scattered, now closer together.

The amniotic bag is very large.

The chorion has the usual longitudinal wrinkles, and is studded with numerous villous excrescences.

The fotal membranes at this stage of developement have probably assumed their definite form.

\section{Phocana communis, Lesson.}

From my examination of the two smallest Phocena embryos whose external form has been previously described in these pages (pp. 34-39), I may add a few supplementary remarks on the foetal membranes in the earlier stages of developement, together with a demonstration of the normal condition of the umbilical vesicle.

I. The orum containing the 7 millim. long embryo, was not, indeed, entire and uninjured, but it allowed one to see that it was about $11 \frac{1}{2}$ centim. in length. of a very elongated shape, the middle portion of about 4 centim. which contained the little embryo, being about the thickness of a little finger $\left(1-1^{1 / 2}\right.$ centim.), while the lateral portions were very thin and narrow, - 2 or 3 millim. in diameter.

The surface of the chorion was perfectly smooth, and, in the alcohol-hardened specimen, very transparent. On being magnified, no villi were visible, but on the other hand, a close-meshed, fine network of vessels below the surface was observable.

I'he allantois was elongated and band-like, but with a larger cavity than was the case in the smallest ovum of Lagenorhynchus acutus. It appeared, as in that ovum, much larger in extent than the amnion.

The amnion consisted of two concentric membranes with an intermediate space. The outer amnion, amnion externum, was composed of embryonic connective tissue, and was comparatively wide and roomy. Within this was a little space filled with fluid, the space being limited inwardly by the amnion internum or verum, which rather closely enveloped the foetus, in the same manner as in the previously described little ovum of Lagenorhynchus acutus.

The umbilical vesicle was very distinct in this fotus. Seen from the abdominal surface of the foetus, especially on the left side, a pear-shaped formation with a narrow stalk was observed projecting from the umbilicus (Pl. IV, fig. 12 v. u.), and about 0.75 or 0.90 millim. in length. The thick peripheral end was about 0.50 millim. in diameter, and the position of the stalked vesicle in the umbilicus was in front, nearest the chest. The umbilical vessels are situated more caudally.

This peculiarity of the umbilical vesicle appearing even in a very early stage of developement, like a small, almost rudimentary organ, which never attains to any great degree of developement, but diminishes gradually, seems to point to the theory - so far as any conclusion may he drawn from the condition of the foetal membranes, - that the Cetacea, as regards their phylogeny, are "old" Mammals, althongh, in many respects, they have retained much of a primitive Mammal type. I do not hesitate in considering that the above described vesicula umbilicalis shows a perfectly normal condition by which the large umbilical resicle in the little 8 millim. long Lagenorhynchus embryo may be judged of, this latter, in my already expressed opinion, having undergone an abnormal. progressive developement in size.

II. The 17 millim. long Phocæna embryo, preserved in alcohol, was enveloped in the amnion, while the long, oval chorion was open. The entire ovum had probably been about 15 centim. long.

The surface of the chorion was wrinkled longitndinally with some small, wart-like elevations here and there in the median region, which envelopes the foetus and its appendages. The peripheral portion of the chorion was quite smooth. A rich, fine-meshed vascular network was seen to be stretched over the entire chorion, when magnified. 
The allantois has at this stage also, the band-like appearance, and adheres to the chorion. The lumen, however, is so large, that when filled, it would probably have the appearance of a long cylindrical bag. which, attached to the umbilical cord, extends out towards both ends of the chorion.

The amnion, as in the smaller Phocæna fretus, was double, the foetus within being closely surrounded by the epithelium stratum of the amnion, outside which was a space filled with fluid, and limited peripherally by a stratum of thin embryonal connective tissue.

The umbilical cord showed a length of about 6 millim. and a diameter of $3 \frac{1}{2}$ millim. The caudal side is more convex and somewhat longer than the cephalic margin. No vesicula umbilicalis was visible exteriorly; it would probably be found in a rudimentary cundition on making serial sections through the umbilical cord.

As regards the remarkable circunstance that the amnion is double, it would be worth a more careful investigation of more copious material; for from that at hand I could form no satisfactory explanation of the whole, on account of its defectiveness. The recorded fact is, however, undoubted, as in both cases I found, on opening the outer amnion, a perfectly transparent membrane within, enveloping the foetus very closely.

No fretal membranes were attached to the third Phocena embryo, as it came into my hands. 

IV.

GUSTAV GULDBERG

\section{ON THE DURATION OF GRAVIDITY}

N

CERTAIN ODONTOCETI. 



\section{On the Duration of Gravidity in Certain Odontoceti.}

$\mathrm{T}$ he question as to how long the Cetacea are pregnant has interested naturalists as long as any cetological literature has been in existence, even Aristotle (1) having discussed this side of the biology of the Dolphin. In the opening short literary survey; it will be seen that this interesting question has been touched upon by the most various authors.

It is, however, only recently that the subject has been more scientifically handled. In addition to Eschricht (40 and 41), ran Beneden (84), and others, G. Guldberg (57), nearly ten years ago made a more careful investigation of the matter with regard to the family Balænopteridæ. In more recent times, James A. Grieg ${ }^{1}$ ) in Bergen has taken up the same theme for treatment, and made some important contributions to it, especially with regard to Balænoptera rostrata and Phocæna communis. Although $I$ am not at present able to shed much new light upon this question, any contribution, however small, is sure to possess a certain amount of interest.

\section{Concerning Gravidity in Lagenorlynehus acutus, Gray.}

According to the hitherto known measurements of this species, the length of the full-grown male must be taken as 2.5 metres and orer. while the female does not attain to that length, being 2.4 metres, or rather less.

Of the fotuses now under discussion. I believe the one measuring 0.95 metres in length to be a fully-dereloped specimen. According to this, the fully-developed young one measures $2 / 5$ of its mother's length. The female fœtuses are probably somewhat smaller than the male, just as the fully-developed females are smaller than the males.

For determining the time of graridity and its duration, we have the following data from the specimens before us.

In the beginning of November, the foetuses vary from 26 millim. to 170 millim., the smallest 8 millim. long embryo not being taken into consideration, as it cannot be looked upon as normal. Nost of them, however, have a length of 140 millim.

In December, a foetus of 195 millim. in length was observed.

In February; a fotus was observed with a length of 455 millim., thus being half developed as regards its length.

In May and June, 4 fortuses were observed, 3 of which were more neary developed — 760 to 820 millim. and one almost fully developed ("full grown") 950 millim. On June 2nd, 1885, according to information kindly given by Prof. R. Collett, a foctus 850 millim. in length was acquired by the Staranger Museum.

According to this, the young should be born in the spring before or about Midsummer, and this also agrees with observations made in other quarters. Thus in the month of June. 1842. in the haul taken at Drøbak, milk was found in the breasts of 4 females. Prof. Rasch. howerer. does not mention having seen small young ones.

Prof. Collett (Nyt Mag. f. Naturridensk. Bd. 2. 1877, pag. 143) mentions a specimen taken on the 8th June, 1867, of which the mammary glands wore full of greyish yellow milk, an observation which agrees with my own supposition.

No observations. however, have been made concerning the time before copulation which may probably be placed in the month of August; the period of gravidity would then be about 10 months. 


\section{?. On the Gravid Period in Lagenorhynchns albirostris, Gray.}

In his interesting and valuable work, "Histoire Naturelle des Delphinides" (p. 137), P. J. ran Beneden says: „Nous ne connaissons presque rien de précis au sujet de l'époque de leur parturition, et des lienx ou elle s'effectue. Une femelle, dont le docteur Joases fait mention, était grosse au mois de Mai. En Juillet 1862, deux femelles pleines, capturées sur les côtes de Suède... . portaient chacune une jeme de 3 pieds de longueur . . En Septembre, 1881, on a capturé un jeune animal qui avait encore une parti de son cordon ombilical. D'après cela, il faut croire que la parturition a lieu au milieu de l'été, sans doute en Juin et Juillet, dit le professeur Sir W. Turner."

The are tempted still to abide by this statement, as the material before is does not allow of any more decisive conclusions.

Of the fotuses here described, one 765 millim. in length was taken in the middle of April, one 720 millim., and one 1130 millim. in length, in about the middle of May. These measurements are not materially at variance with Sir. William Turner's opinion, with which van Beneden also coincides, namely, that it brings forth in the middle of summer. As previously stated in the section on this species (p. 27), I take the size of the newly-born animal to be $3 / 7$ that of the mother.

As the measurements are far from numerous, no more direct conclusions can at present be drawn.

\section{On Gravidity in Orea gladiator, Lacépède.}

Acquaintance with facts concerning this cosmopolitan Cetacean's copulation and gestation is also very slight. P. J. ran Beneden, in his interesting "Histoire naturelle des Delphinides", etc. 1889, says: "Nous ne connaissons rien des amours de ces Cétacés (i. e. Orca gladiator), ni des lieux ou ils mettent bas; nous savons seulement qu'ils vivent en polygamie comme les Cachelots, et nous n'avons que quelques exemples de femelles pleines capturées, mais en trop petit nombre pour apprécier ì quel époque de l'amnée ils mettent bas, et pour connaitre les lieux ou cette opération s'accomplit. Dans la gamme de dix-huit individus qui s'est perdu au mois de Février, 1871, sur les côtes de Shetland, se trouvaient deux femelles pleines, dont un fretus mesurait environ deux pieds. La mère, aydnt au moins dix-huit pieds, il y a lieu de croire que l'accouplement, ou du moins la fécondation, a eu.lieu la fin de l'été."

This supposition of Van Beneden is very correct on the whole, and more light is thrown upon these circumstances by observations taken on the coast about Bergen.

The stranding of Orca gladiator is not an uncommon occurrence on the coasts of Norway, and for the last ten years, fœtuses from such specimens have been collecterl and preserved. James Grieg (Cetological notes in the Bergen Museums Report for 1889) furnishes the following data:

In the beginning of

February 1885,62 specimens were taken on Bildøen in the neighbourhood of Bergen, among which were 6 young ones and 12 gravid females, whose small fotuses measured from 408 millim. (the smallest) to 875 millim. in length.

On the 18th Feb. 1886, 3 foetuses were sent to the Bergen Museum from Herlo near Bergen, one 590 millim. one 820 millim. and one 860 millim. in length.

November, 1887, in the middle of the month, 13 specimens of Orca were taken on Bildøen near Bergen, 2 of which were gravid females. Their fretuses were 1870 millim. and 2080 millin. in length.

On the 26th Jan. 1891, a young female, 2.51 metres in length was taken. It was stuffed and placed in the University's Zoological Museum (Christiania), its skeleton being placed in the zootomical collection of the university.

On the 29th April, 1892 , Bergen, according to information obtained from Dr. Danielssen, acquired a female fotus 690 millim. in lengtlı.

When we put together these facts about fretuses, from that 2 feet (about 62 centimetres) in length, from the Shetland Isles, to those mentioned here, their length appears to vary between 40 and 87 centimetres in the month of February. In April, we have only one observation, a specimen 69 centim. in length (1892). In November, Grieg has measured two fretuses, one 1.87 metres, the other 2.08 metres in length. The latter may certainly be considered to be fully developed. Toung ones accompanying the mother animal have frequently been observed: the 2.760 metres long skeleton of the young one taken on the 27th Sept. in Limfjord, Denmark, and described by Lütken (see literature 82) is well known in cetological literature. A female, 5.25 metres in length, and accompanied by her young one, was taken, in 1878, in Trondhjem's Fjord (cf. R. Collett, Nyt Nag. f. Naturvidensk. 22 Bd. p. 250). According to our observations here mentioned, a young one $2 \frac{1}{2}$ metres in length was caught at the end of January, 1891, and 6 young ones were observed in the take on Bildøen (Bergen) in February, 1885. 
From this, it seems most probable, judging from observations hitherto made, that Orca females give birth to their young towards the end of the year, late in Norember and in December. Copulation probably takes place at the same time of year, the gravid period being 12 months, which Grieg also supposes to be the case.

The young one caught at the end of January, 1891, may without doubt be taken to be between 1 and $1 \frac{1}{2}$ months old.

The length of the new-born animal is probably rather more than 2 metres $(2.08-2.20)$ and, as an average, ought to be taken as $2 / 5$ of that of the mother. The facts here stated are, of course, too few to allow of our drawing certain conclusions, and giving fixed measurements, but I have every reason to believe that they do not greatly differ from the actual circumstances, as we have analogies in other species of Odontoceti.

\section{On gravidity in Phocata communis, Lesson.}

As the curator, James A. Grieg (l. c.), on a basis formed by the rich material in the Bergen Museum, has treated very exhaustively the subject of the gravidity of the common porpoise with regard to its duration and the time of copulation, I shall only subjoin a few remarks, adding some new observations, and comparing them with those previously made by Grieg.

Ang. 31 st, 18921) Mr. Bistrup, Greenland, a foetus 7 millim. long, measured by G. Guldberg.

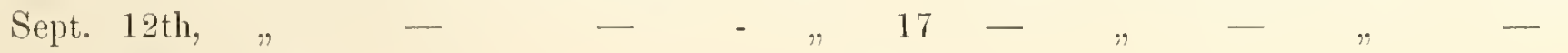

"18th, 1888, Dr. Nansen,

Oct. 12th, 1889, Bergen Museum, 14 th,

" $" 1893, \quad-\quad-$

19 th, $1888, \quad-\quad-$

"26th, 1892, - -

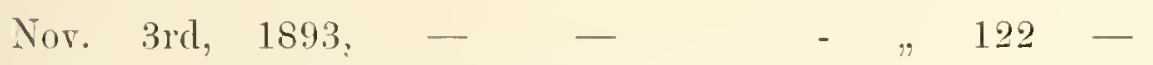

In Nor. 1889, Huseum in Throndhjem -

Nor. 13th, " Bergen Musem

26 th, 1886, - -

Dee. 4th, 18s8, - -

"9th or 19th 1891, - - -

Jan. 17th, 1890, - - -

$$
\text { 28th, } 1884
$$

Feb. 10th, 1893,

28th. 1881.

29 th, 1892,

In Harch, the length varies from

From 15th to 29th April

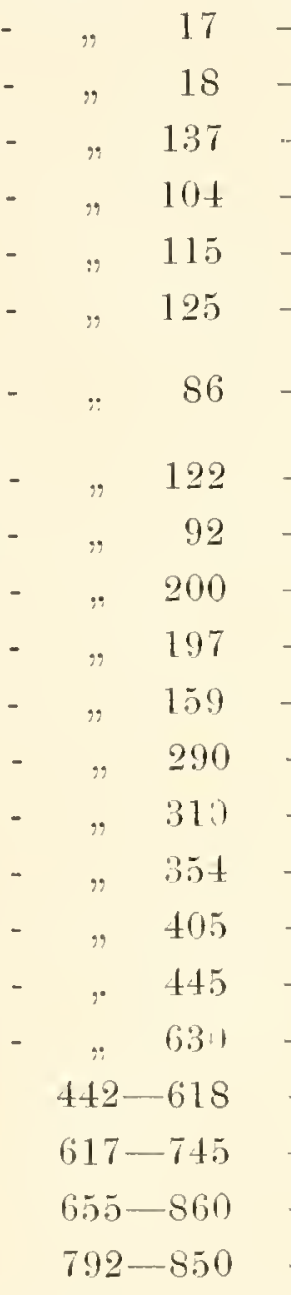

J. A. Grieg.

-

-

f according to information supplied

I by Dr. Danielssen.

measured by J. A. Grieg.

according to the curator, Storm.

according to J. A. Grieg.

$$
\begin{array}{llc}
- & - & - \\
- & - & - \\
- & - & \text { Dr. Danielssen. } \\
- & - & \text { J. A. Grieg. } \\
- & - & - \\
- & - & - \\
- & - & - \\
- & - & \text { Dr. Danielssen. } \\
\text { to J. A. Grieg. }
\end{array}
$$

" 3rd to 10th May

". 2nd to 22nd June

From the above scale of measurements, in which I have only taken notice of measurements made by Dr. Darielssen, James Grieg, Storm and myself, it appears that the porpoise, in the northern parts of the Atlantic and in the Arctic Ocean is pregnant for $10 \mathrm{months}$ or possibly longer, as the conception of the 7 millim. long embryo taken on Aug. 31 st is assigned to the beginning of that month. The fully-developed fotus has probably an arerage length of s00 millim., and the birth probably takes place in the month of June. either before or at Midsummer.

Tames Grieg, in his treatise, has mentioned the most important observations in the literature upon the gravidity of the Phocena. As a number of the carlier observations and measurements were not made with special reference to the subject in hand, in which it is of importance that not only the length of the fretus, but also the time of the mother animal's capture be giren with absolute accuracy, I have unly placed in the above table such measurements as I know to be accurate. Were we to take all the instances in literature, there would immediately arise greater variations and uncertainty. The reason

1) James A. Grieg, mentions, in his treatise. a foctus tiken in Trondhjen's Fjord in Aug, 1887, which, according to Storm, measured fi) centim. (according to my mensurement of the specimen preserved in alcohol, 41 centinı.) This dimension differs so considerably from the rest, that I must discegard it until further facts are fortheoming. 
for this may partly be that some dates mentioned are giren from memory, the capture of the mother animal haring taken place earlier, and the date may thus easily be inaccurate; partly, that possibly the copulating time with the Phocæna from southern latitudes is not the same as with those which inhabit more northern latitudes.

It is sufficiently well known from different animal forms that the size of the new-born animal may vary. In man and in mammals in domestication, it is well known that the size of the newborn ynung varies rery much. Grieg's obserrations on small porpoises - one 885 millim. in length, taken on June 11th. 1887, and another 970 millim. long taken on July 17th. 1888, are very instructive, and only strengthen the conclusions I have drawn. In placing such wide limitscopulation from June to October; gravidity lasting 9 or 10 months, parturition between March and July; and the length of the newly-born young one from 700 to $\$ 60$ millimetres. - Grieg is fully justified in consideration of literary and personal observations. I would, however, make the limit somewhat narrower, and, for reasons already mentioned, am not inclined to attach much importance to earlier literary statements. which hare not special reference to the subject in hand. For the present, at any rate, I shall confine myself to the observations abore mentioned, as they were made with the special riew of obtaining accurate facts as to the size of the embryo at different times of the year. It is better to hare few and absolutely accurate obserrations than many of less accuracy. I would not by this hare it thought that I undervalue earlier observations which may be quite as useful for other purposes. New series of observations will show whether the above reasoning is correct. 


\section{Literature.}

1. Aristotle: Histoire des Animaux d'Aristote, traduite par J. Barthelemy St. Hilaire. Tome I---III.

- Thierkunde Aristoteles, übersetzt ron H. Aubert und Fr. Wimmer. Bd. I-II.

2. Galen: Kuhn Ausgabe, Leipzig 1821, Libri IV et TIII.

3. Renaud: Relations des Voyages faits par les Arabes et les Persans dans l'Inde et à la Chine dans le IXe Siècle de l'ère chrétienne. Taris 1845 . T. I and II.

4. Edrisi: Géographie, traduite de l'Arabe en français par P. Amadée Jaubert. Paris 183ł; dans "Recueil de Voyages et de Mémoires". T. 5 \& 6.

5. Ed-Dimichqui. Nanuel de la Cosmographie du moyen age, traduit de l'arabe "Nokhbet ed-dahr fl'adjaib-il-birr walbah'r". par M. A. F. Mehren. Paris $187 t$.

6. El-Kazwini: Kosmographie. Aus dem arabischen übersetzt ron Dr. Hermann Ethé. Leipzig 1868.1 .1$.

7. Conrad Gesner: Historia Animalium. L. IY. 1558.

8. Olans Magnus: Historia Gentium septentrionalium, etc. Lib. XXI. c 13. De monstroso Pisce in Littore septentrionalis Anglice IIDXXXII reperto, etc.

9. Belon: Histoire naturelle des étranges Poissons marins, plus la. Figure et Description du Dauplin; Paris 1551.

10. (̇uilielni Rondoletii Medicine in schola Nonspeliensi professoris, Libri de Piscibus marinis, Lugduni $15 n$ t.

11. Loan. Jonstoni Historial maturalis de Piscibus et Cetis, $16+9$.

12. Peder Cläusson Friis: Samlede Skrifter, udgivet af prof. dr. Gustar Storm, Christiania, 1881.

13. Olans Worm: IJusemm Wormianum, Lugd. Batar. 1656. fol. 282.

14. 'Thomas Bartholin: Historiarum anatomicarum rariorum Centurice II; historia XXY. Amstelodami, 165 .

15. Friedrich II artens: Spitzbergische oder Grönländische Reisebeschreibung. Hamburg, 1675.

16. I. Th. Klein: Historix piscimm naturalis promovendæ missus primus de lapillis eorumque numero in craniis piscinm. cum prafatione de piscium auditu. Accesserunt I anatome tursionum, etc. Gedani, 1740.

17. Joh. Andersen: Nachrichten ron Island. Grönland und der Strasse Daris. Hamburg $17 t 6$.

18. A. Brisson: Regnum animale. in classes IX, 1762.

19. Linllitus: Srstema natmre. Editio X \& XIll.

21). Frik Pontoppidan: Norges naturlige Historie. Kijohenharn 1752; Bd. I \& Il.

21. - Versuch einer natiirlichen Historie von Norwegen, aus dem Dänischen ïbersetzt von Joh. Adolph Scheiben. Lopenhagen $1753 ; \mathrm{Bd} .11$.

22. Gunnerns: Kgl. Videnskabernes Selskab i Trondlyjem. Bd. Il. 1765, og IV, 1768.

23. Otho Fabricins: Fauna Grenlandica. Hatinie 1780.

24. Jorgen Landt: Forsog til en Beskrivelse orer Fierverne: Kjobenlarm, 1800.

25. ('. S. Sonnini: Histoire naturelle des Cétacés. Paris $180 t$.

26. Lỵg y ye: Tidsskrilt for Natmridenskabenc. Kjobenharn, 1825.

27. J. G. Schueider: S:mmlung rermischter Abhandlungen zur Aufklärung der Zoologie. Berlin 178t. Ueber den Bau und Oeconomie der Wialtische.

28. John Hnuter: Philos. 'Trans.. vol. LXxill. 1787. Observations on the Structure and Economy of Whales. 
29. La Cépède: Histoire naturelle des Cétacés. Paris, 1804.

31). W. Scoresby: jun: An Account of the Arctic Regions, etc. Edinburgh. 1820; vols. I \& II.

31. Friedrich Kries: Wr. Scoresby's des Jüngeren Tagebuch einer Reise auf den Walfischfang, etc. Aus dem Englischen iibersetzt u. mit Zusätzen u. Anmerkungen rersehen. Hamburg, 1825.

32. R. P. Lesson: Historie naturelle des Mammifères et des Oiseaux. Cétacés. Compléments des Gurres de Buffon. 'T'. I, 1. Paris, 1828 .

33. Brandt und Ratzeburg: Medicinische Zoologie, etc. Berlin 1829; Bd. I, 40.

34. Georges Curier: Leçons d'Anatomie Comparée: Paris 1835-46. 'Tom. I--VIll.

35. - Le Régne animal. distribué d’après son Organisation. Bème Edition. Paris 1836.

36. F. Cuvier: De l'Histöire naturelle des Cétacés; Paris 1836. avec Planches.

37. Willelm Rapp: Die Cetaceen. zoologisch-anatomisch dargestellt. Stuttgart und Tiubingen, 1837.

38. Karl Ernstr. Baer: Ueber Entwicklnngsgeschichte der Thiere, II Theil. Königsberg, 1837 (p. 257 ).

39. D. F. Eschricht: De organis que respirationi et nutritioni fotus mammalium inserviunt. Hafnice. 1837.

4n. - Undersogelser orer Hvaldyrene. Det Kgl. Danske Tidenskabernes Selskabs naturvidenskabelige og mathematiske Afhandlinger. 11 te Del. 184t-1845.

4:. Z Zoologisch-anatomisch-physiologishe Untersuchungen iiber die Nordischen Walthiere. Leipzig, 1849, folio mit 15 Tafeln.

42. R. Owen: Comparative Anatomy and Plysiology of Vertebrates. Tol. ITI.

43. W. Turner: Transact. Roy. Soc. of Edinburgh, vol. 26. 1871.

44. - Proc. Roy. Soc. of Edinburgh 1876.

45. John Anderson: Anatomical and Zoological Researcles. comprising an Account of Zoological Results of the two Expeditions to Western Sumnan in 1868 and 1875. Vols. I and II. London 1878.

46. Kölliker, Albert r.: Entwicklungsgeschichte der höheren Thiere. 1879-81.

47. Beauregard et Boulart: Journal de l'Anat. et de la Pliysiologie ete. 1882.

48. Chabry et Boulint: Tournal de l'Anat. et de la Physiol. 1883.

49. Balfour: Traité d’Embryologie et d'Organographie comparées, traduit par Robin et Mocquard, Paris 18ৎ.̆, vol. II.

50. W. H. Flower: Kosmos, 7 Jahrg. 5 n 7 Heft. (13 Bd. p. 358-368 und 525-532).

51. Scarles T. Word: Erolution of Cetacea; Nature. Vol. 29, no: 737 pp. $147-148$.

52. John A. Ryder: On the Development of the Cetacea, together with a Consideration of the probable Homologies of the Flukes of Cetaceans and Sirenians, in U. S. Comm. of Fish and Fisheries. P. XIII. Report of Commissioners for 1885 . Washington 1887.

53. On the probable Origin etc. in Amer. Naturalist. Tol. 19. May 1885, pp. 515-519.

54. II ax Wroler: Studien üher Sängethiere. Ein Beitrag zur Frage nach dem Ursprung der Cetaceen. Jena 1886.

55. Klaatsch: Die Eihüllen ron Plocena communis, Cuv; in Arch. f. mikr. Anat. Bd. 26. 1886.

56. Eug. Korschelt: Zur Phylogenie der Cetaceen. Kosmos 19 Band. 1886 pag. 210-219.

57. G. Guldberg: Zur Biologie der norlatlantischen Finnwalarten. Zoolog. Jahrbücher 1886.

Bidrag til Cetaceernes Biologi. Christiania Vidensk. Selsk. Forh. 1886, no. 9.

58. W. Kükenthal: Vergleichend-anatomische und entwicklungsgeschichtliche Untersuchungen an Walthieren: I Theil, Jena, 1889. II Theil, Jena. 1893, in Denkschriften der medicinisch-naturwissensehaftlichen Gesellschaft zu Jena; dritter' Band, Jeni, $1889-1893$.

59. - - T'eher Entstehung und Entwicklung des Sängethierstammes. Biologisches Centralblatt, Bd. XII, 1892.

60. - Zur Entwicklungsgeschichte der Wale. Verh. d. deutsch. Zool. Gesell. 3 Vers. Göttingen. pag. 69-75.

61. W. Janes: L'eber Zeuglodonten aus Aegypten und die Beziehung der Archæoceten zu den übrigen Cetaceen. Palæont. Abh. herausgegeben von WT. Dames und E. Kayser. Neue Folge Bd. I. Heft 5. Jena. 189t.

Special literature of Latgenorlynthus acutus, Gray.

62. J. E. Gray: Phocerna acutus. in Brookes's Cat. Mus. 39, 1828, and Delphinus acutus in Spec. Zool. 2. 1828, Fischer. Frn. Mamm. 656 .

63. - Lagenorhyuchus acutus. Zoology of "Erebus and Terror" 1846.

64. Schlegel: Delphinns Eschrichtii. Abh, ans dem Gebiete der Zoologie und vergl. Anat. $18+1$.

65. H. Rasch: Telphinus lencoplevus, Nova Species descripta, cum Tab. II. Christiania 184:3.

66. - Beskrivelse orer (n i Christianiatjorden fanget ny delfinart - in Nyt II agasin for Nituridenskaberne, 4 (1) Bilil. 1845 . 
67. S. Nilsson: Dclphinus lercoplerrus; Skandinarisk Fauna, Däggdjuren, 2dra upplagen, 1847.

68. Claudius: Dissertatio de Lagenorhynchis. $4^{0}$ Kilix, 1853.

69. Pucheran: Rerue et Mag. de Zoologic, Notices mammalogiques, 1856.

70. Eschricht: Comptes rendus de l'Acad. des sciences de Paris, Juill. 1858.

71. Lilljeborg: Öfrersigt af de inom Skandinarien anträffade hralartade däggdjur, Upsala Unir. Årsskrift. 1861, pag. 9. 72. - Sreriges ocl Norges däggdjur, 1S 14 , vol. II.

73. Poelman: Notices sur m Delphinus Eschrichtii etc. - Bull. Acad. Roy. Belg. 2 Ser. T. XVIII, 1864.

74. Malmgren: Bcobachtungen und Anzeichnungen ïber die Säugethierfama Fimmarkens u. Spitzbergens: Troschels Archir 1864, pag. 63.

75. P. J. van Beneden: Recherches sur les Cétacés. Mem. Acad. Roy. Belg. T. XXXII, 1860.

76. J. E. Gray: Catalogue of Seals and Thales in the British Hus. 1866, pag. 270. Lagenorhynchus acutus, and pag. 273 L. leveoplerrus.

77. - Synopsis of the species of whales and dolphins in the collection of the British Museum 1868 (Electra acuta).

78. A. W. Malm: Hvaldjur i Sreriges Museer. 1869. Kgl. Svenska Tetenskaps-Akad. Handl., ny f. Bd. 9 no. $2,1871$.

79. R c'ollett: Meddelelser on Norges Pattedyr ete. Nyt Mag. f. Naturridensk. Bd. 27.

80. IT. H. Flower: On the Characters and divisions of the family Delphinidæ. Proc. Zool. Soc. Norbr. 1883.

81. - List of the specimens of Cetacea in the Zool. Dep. of the Brit. Mus. London.

82. Lütken: Kritiske Studier orer nogle 'landhaler af Slægtcrne Tursiops, Orea og Lagenorhynchus. Kongl. Danske Tid. Selsk. Skir. 6te Rækkic, nat. mathem. Afd. IT, 6. 1887.

83. James A. Grieg: Cetologiske Notiser. Bergens Museums Aarsberetning for 1889 no. 4. pag. 19.

S4. P. J. ran Beneden: Histoire naturelle des Delphinides des mers d'Europe, Bruxelles 1889, pag. 147 -153.

85. Fredrich II. 'True: Contributions to the natural history of Cetaceans, a review of the family Delphinidx, in Bulletin of the United States National Nusemm no. 36. Washington 1889.

\section{Special Literature on Lagenorhynchus albirostris, Gray.}

86. J. E. Griy: \%oology of the Toyage of "Erebus" and "Terror", 1839-43; Mammalia 1846, p. 34.

Ann. and Mag. of Nat. Hist. vol. 17, 1846, p. St.

87. Brightwell: Ann. and Mag. of Nat. Hist. rol. 17, 18t6, pag. 21. Tab. 2.

88. Eschicht: Delph. Ibsenii, Kgl. Danske Vid. Selsk. naturv, og math. Afh. 12te del, p. 297.1846.

89. Sren Nilsson: Skand. Fama, Däggdjuren, 2den uppl. pp. 600-602. 1847.

90. M. Clandius: Dissertatio de Lagenorhynchus. Kilix. 1853.

91. P. J. ran Beneden: Recherche's sur la Faune littorale de Belgique; Cétacés. Mém. Acad. Roy. de Belgique. T. XXXII. pl. 1. 1860.

92. Lilljeborg: Öfrersigt af de inou Skand. anträffade hralart. Däggdjur. Upsala Univ. Arsskrift 1861, p. S.

93. Suluderall: Öfrers. af Kgl. Tet. Ak.'s Förh. 1861. p. 385, taf. VII.

94. Th. J. Moore: Amn. and Mag. Nat. Hist. 3 scr. rol. XT, p. 268. London 1863.

95. Cromer: Amm. Nat. Hist. vol. XTTll, 1866.

96. J. E. Gray: Catal. of Scals and Whales, etc. 1866.

97. - Synopsis of the species of Whales and Dolphins in the Collect. of the Brit. Mlus., p. S. pl. 10, fig. 2.

98. A. IT. Malm: Hraldjur i Sreriges Husecr; i Kgl. Sr. Tet. Ak. Handlingar, ny F. Bd. 9, no. 2, pag. 70, tafl. III, fig. $21-23$ etc. 1871.

99. Lilljeborg: Sreriges och Norges dïggdjur, 1874. T. II, pag. 1042, etc.

100. J. Tr. Clark: Proc. Zool. Soe. London. 1876, p. 686.

101. R. Collett: Nyt Mag. for Naturridenskaberne. 1876.

102. Jul. Munther: Nittheil. a. d. Naturwiss. Vereine im Neu-Pommern u. Rügen (Jahrgang VTIT) 1876.

103. D. J. Cunningham: Description of a young Specimen of the Delphinus albirostris. Proc. Zool. Soc. 1876, p. 679.

104. J. Sparre Schneider: Tromso Musems Aarshefter. 1878.

105. T'h. Southwell: The Zoclogist. Oct. 1879 and Zoologist. 3. rol. 1868 p. 364; rol. 10. 1886.

106. J. W. Clark: Proc. Zool. Soc. April 1879.

107. J. M. Campbell: Scottish Naturalist. Yol. 6, 1880.

108. G. A. Guldberg: Bidrag til kundskab om Delpl. allirostris; Christiania Vidensk. Selsk. Forlu. No. 3, 1882.

109. - On subfossile og forhistoriske knokkelfund i Norge; Nyt Mag. f. Naturvidensk. Bd. XXX. 
110. R. Collett: Meddelelsel om Norges Pattedyr i Aarene 1876-81; i Nyt Hag. for Naturvidensk. Bd. 27.1883.

111. II. H. Flower: Proc. Zool. Soc. London, 1883, p. 489.

112. Cleland: Journal of Anatomy and Physiology, XTIII, 1884.

113. P. J. ran Beneden: Bulletins de l'Acad. Roy. Belgique. T. VIII, no. 12 or 'T. X, 1885.

114. Th. Southwell: Notes on the White-beaked Dolphin. Trans. Norf. and Norw. Naturalist's Society, Yol. IV. 1885.

115. Nax Weber: Teber Lagenorhynchus albirostris, Gray, in Tijdschrift der Nederlandsche Dierkundige Tereenigung, 1887.

116. Chr. Fr. Lïtken: Kritiske Studier over nogle 'T'andhialer af Slægterne 'Tursiops, Orca og Lagenorhynchus. Danske Tidensk. Selsk. Skr. 6te Riekke. naturvid. og matl. Afd. IV, 6. 1887.

117. James A. Grieg: Hralstænget red Bildöen den 15de April 1889; i Bergens Iluseums Aursberetning for 18s8, Bergen, 1889.

118. P. J. ran Beneden: Histoire naturelle des Delphinides des mers d'Europe. Bruxelles, 1889.

119. Fred. W. True: Contributions to the Natural History of the Cetaceans, a Review of the family Delphinidxe. In Bulletin of the U. S. National Museum, No. 36, Washington. 1889.

120. Henry Laver: Delphinus albirostris, ete. Zoologist, Tol. 13, pp. 382, 383.

121. Wm. Turner: Notes on the White-beaked Dolphin. Proc. Roy. Phys. Soc. Edinburglı. Vol. 10, pp. $14-19$.

122. O. T. Aplin: White-beaked dolphin (U. albirostris) on the Norfolk Coast. "Zoologist" rol. 14, p. 180 and 217. 
Plate I. 


\section{Lagenorhynchus acutus, Gray.}

Fig. 1. An 8 millin. long fœetus of Lagenorhynchus acutus, Gray. Magnitied. The embryo is lying with the left side up in situ in the amniotic bag, which is opened. Am. am. = flaps of amnion; all $=$ allantois; $u=$ umbilicus and umbilical cord (?); $c=$ cauda; $F p$. = foremost part of the body; $b=$ resicle-like expansions. Drawn by Dr. F. Nansen.

2. The ventral surface of the same embryo. deformed. $c=$ cauda, which is very long and bent; $u=$ umbilicus. Magnified 8 times. Drawn by Dr. F. Nansen.

3. Right side of the same fœetus. $F=$ foremost part of the body, which is injured and deformed: v= ventral surface; $d=$ curve of the dorsal surface; $u=$ umbilical cord; $c=$ cauda. above which is a blind hollow. Nagnified 8 times. Drawn by Dr. F. Nansen.

4. Back of the same foetus. $F=$ foremost, injured part of the body; $H=$ hindmost, uninjured part. Magnified 8 times. Drawn by Dr. F. Nansen.

5. Sagittul section through the same fretus. The section is considerably to the outside of the median plane. The details of the anterior part of the foetus are not shown in the drawing. Seg = proto-vertebræ; $c=$ cauda; $a=$ anal depression; $u=$ umbilicus; $\lambda . a=$ allantoic passage; hep $=$ liver; $c o r=$ heart. Drawn by Prof. G. Guldberg. with Zeiss obj. A* oc. no. 2. Abbe s camera lucida.

6. Median section through the same fretus. Seg 1. $\operatorname{seg} 2 . \operatorname{seg} 3=$ proto-vertebres in the foremost. middle and hind parts of the hody; $c h=$ chorda dorsalis; med = medullary tube; $c b=$ brain vesicle enlargement; $F t=$ tore-gut; $\operatorname{cor}=$ heart: hep $=$ liver; $t=$ gut (?); $\iota=$ mbilicus: $u=$ anal depression. Drawn by O. Bergh, medical student.

7. Hind end of the same fretus, showing the invagination of the ectoderm for the formation of the anus, in a section to the side of the median line. $c=$ caudal end; med = medullary tube; $\|=$ anal depression. Zeiss obj. aa oc. 2, Abbes camera lucida. Lrawn by Prof. G. Guldberg.

8. Section of the integument on the dorcal surface of the same foutus, above the medullary tube. ep = epidernis; de $=$ corium; med = medullary tube. Drawn by Prof. G. Guldherg. 

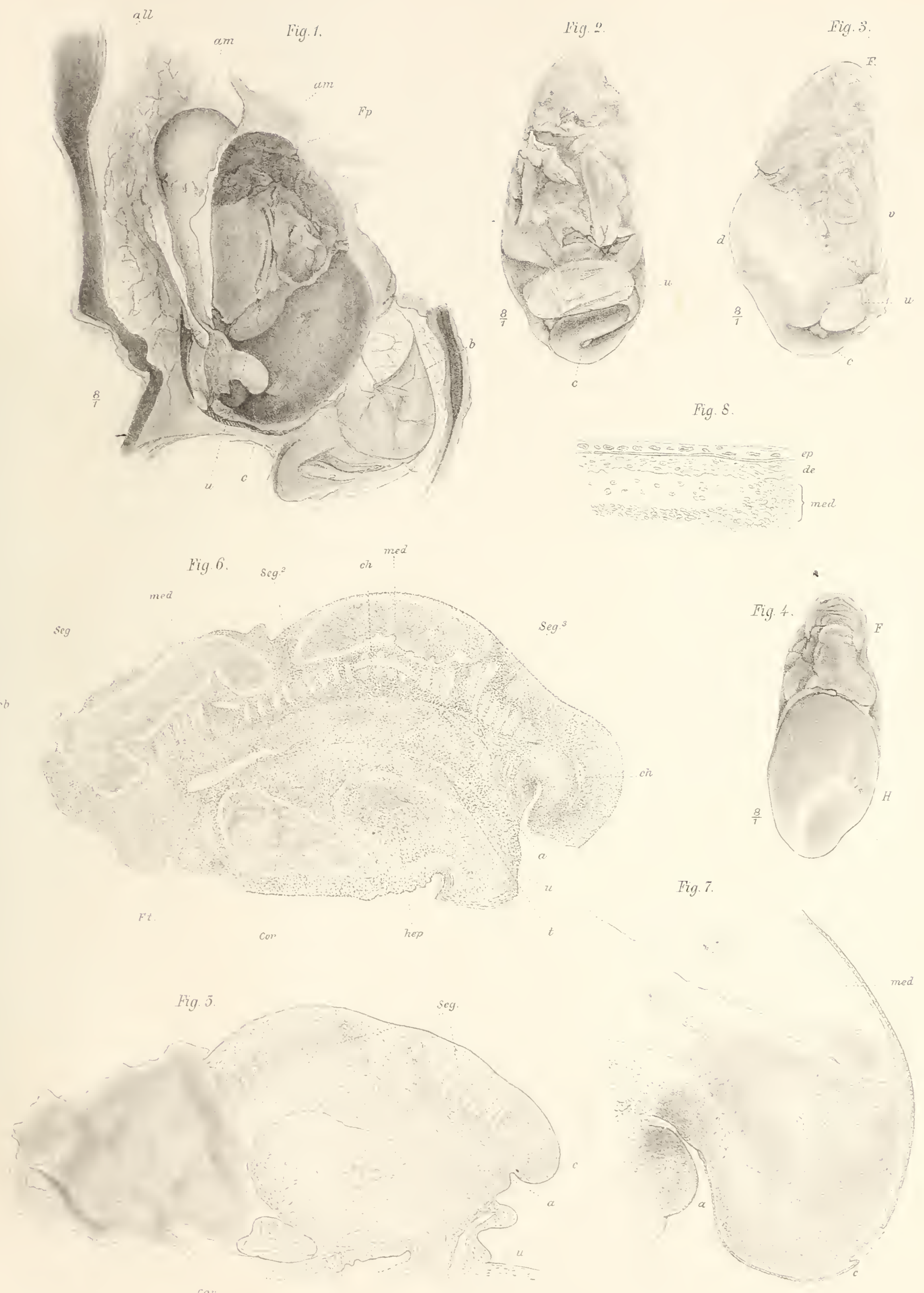

Plate II. 


\section{Small Fotuses of Lagenorhynchus acutus, Gray,}

with the incipient characters of Odontoceti.

Fig. 1. Lagenorhynchus acutus, Gray, 26 millim. long foetus, seen from the right side: natural size. A distinct constriction of the neck is visible, a short facial region and rounded cranium with the nasal aperture high up; forelimbs distinct; rudiments of hind-limbs not visible to the naked eye; tail conical and relatively large.

2. The same fretus seen from the left side: natural size.

3. Same fretus. seen from the ventral surface: natural size. Distance between nasal aperture and mouth cleft already considerable.

t. Same fotus, seen from back: natural size. Slight depression in the back of the neck, indicating the 4th rentricle.

5. Same fortus, magnified 3 times. seen trom the right side. The pronounced foetal flexures are noticeable. the constriction of the neck. a rentral and a lateral side-furrow; a prominence to the side of the membrum genitale (rudiments of hind-limbs). and a well-developed. conical tail.

6. Same firtus. magnified 3 times, seen from the left side.

7. Same futus. magnitied 3 times, seen from the ventral surface.

8. Lagenorhynchus acutus. Gray. 30 millim. long foetus, seen from the right side: natural size.

9. Lagenorhynchus acutus. Gray; 45 millim. long fotus, seen from the left side: natural size. The Cetacean characters are here more conspicuous. Pigmentation at the back of the head begins to appear.

- 10. Same furtus. twice the natural size. Left side.

. 11. Same fretus. twice the natural size. Tentral surface.

. 12. Lagenorhynchus acutus. Gray. 94 millin. long foetus; natural size, right side. Pigmentation of the skin in the region of the back of the neck and on the back. is already distinct.

.. 13. Same furtus. left side. natural size.

. 14. Same fortus, ventral surface. natural size.

Figs. 1-7 and figs, 12-14 are drawn hy H. Bucher. jun. in Bergen; figs. 8-11 are drawn by Olaf Bergh. medical student. Christiania. 


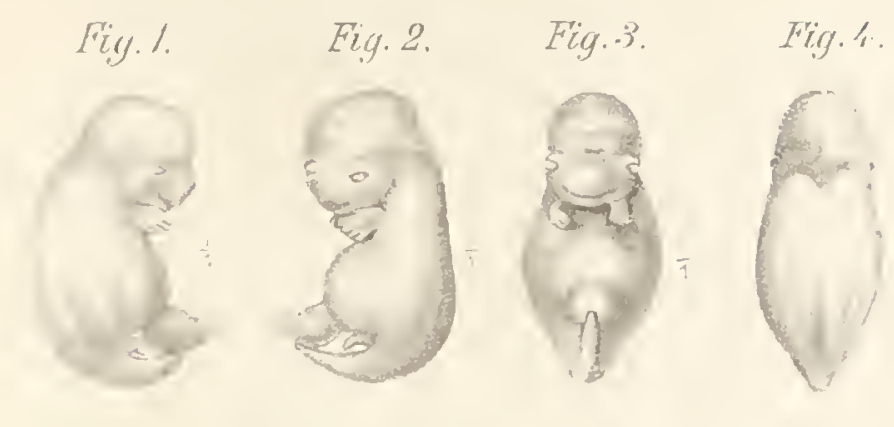

Fig. 7.
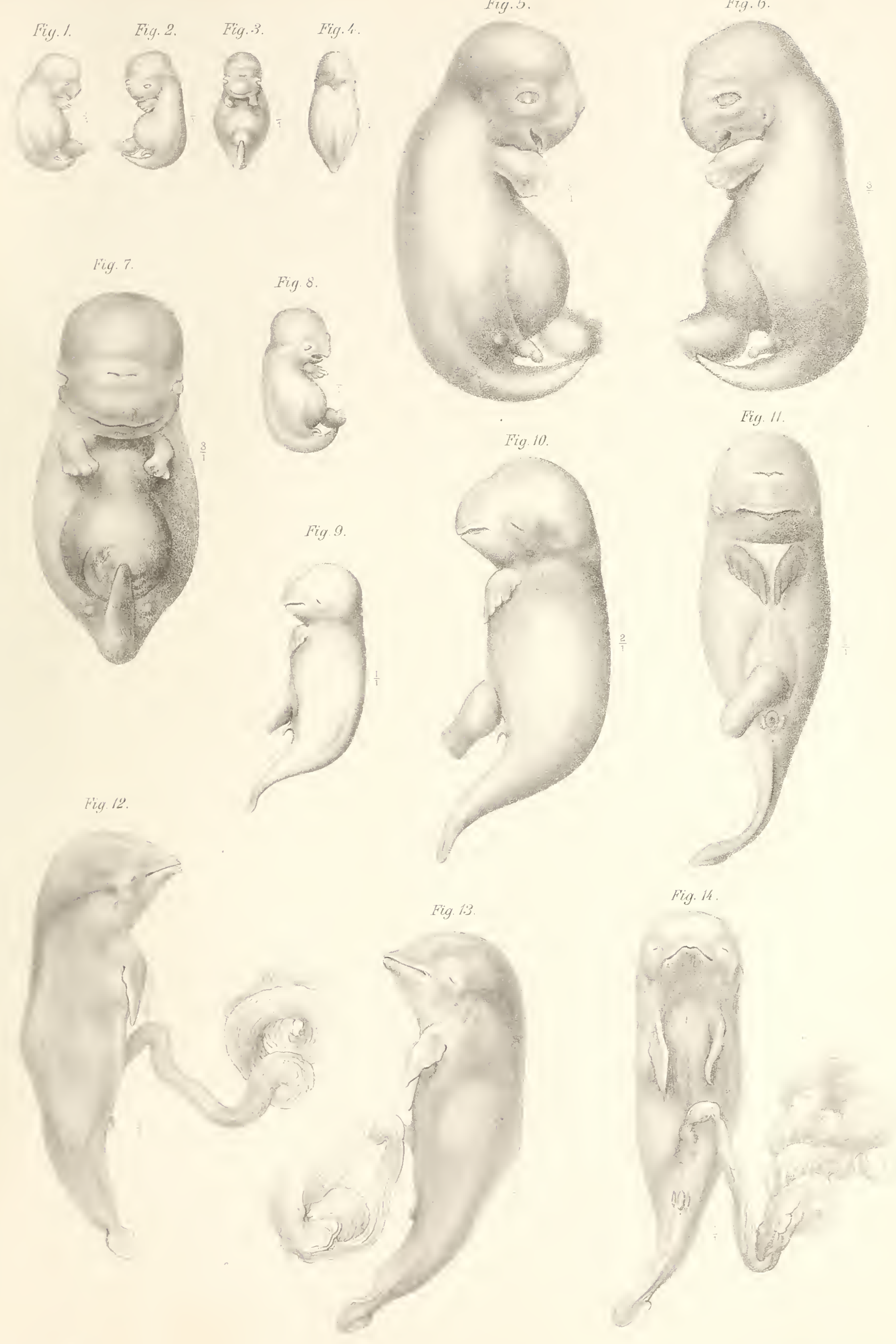

Plate III. 


\section{Two Fotuses of Lagenorhynchus acutus, Gray, \\ with the incipient claracters of Delphinidx.}

Fig. 1. Lagenorhychus acutus. Gray. 110 millim. long foetus, with umbilical cord. and a considerable portion of the fortal membranes. which is represented. The foutus exhibits incipient dorsal fin, distinct neck-band, and rounded triangular tail-lohes. The fortal head-flexure is still conspicuous. The pectorals hare assumed their characteristic shape. The distribution of colour in the region of the back of the neck is distinct.

2. Lagenorhynchus acutus, Gray, 170 millim. long foetus. The fotal head flexure has diminished considerably. The Dolphin characters make their appearance. A darker colour has diffused itself over a large portion of the dorsal surface, and its distribution already indicates the specific characters. 
Fig. 1.

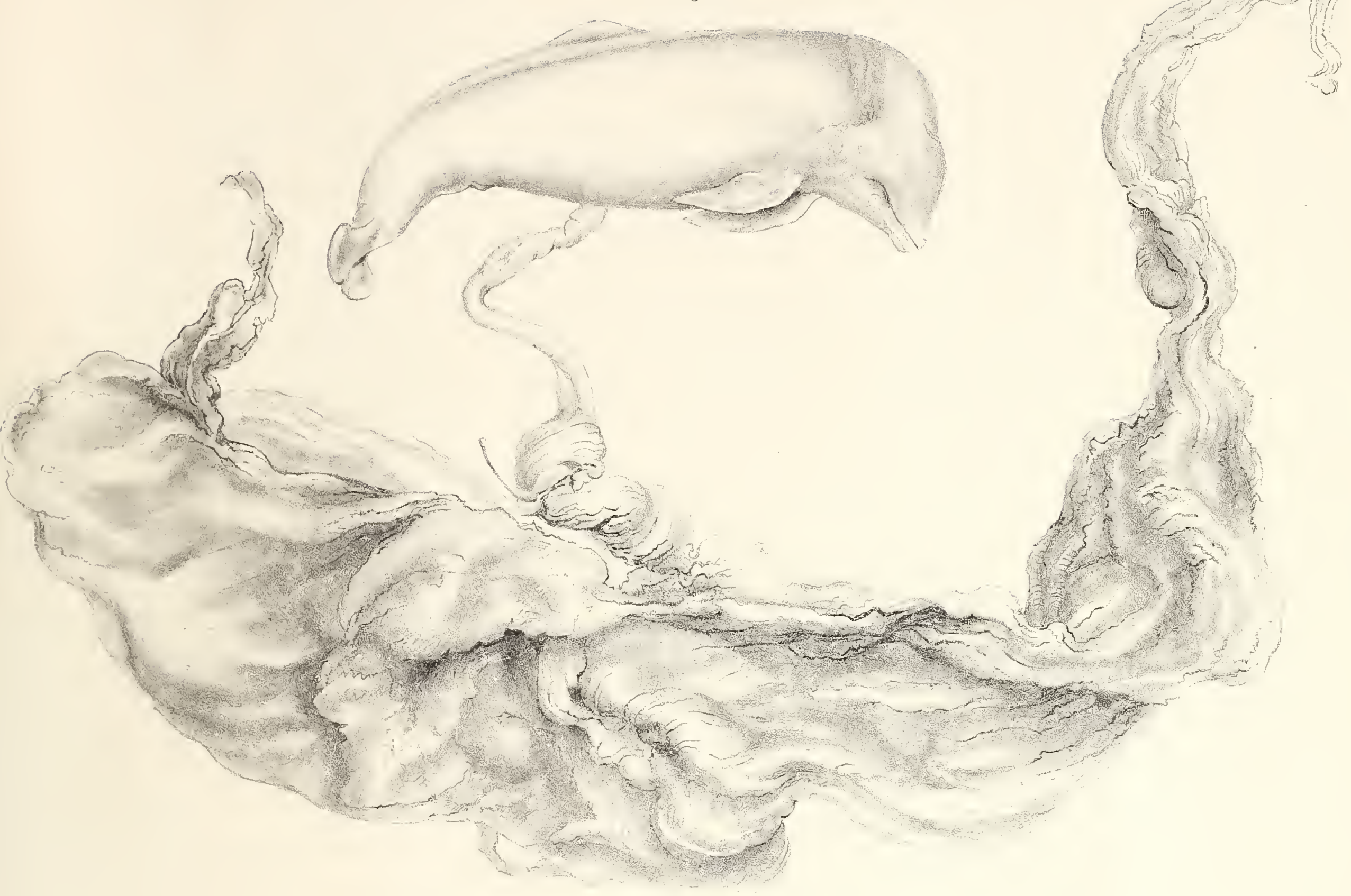

Fig. 2.

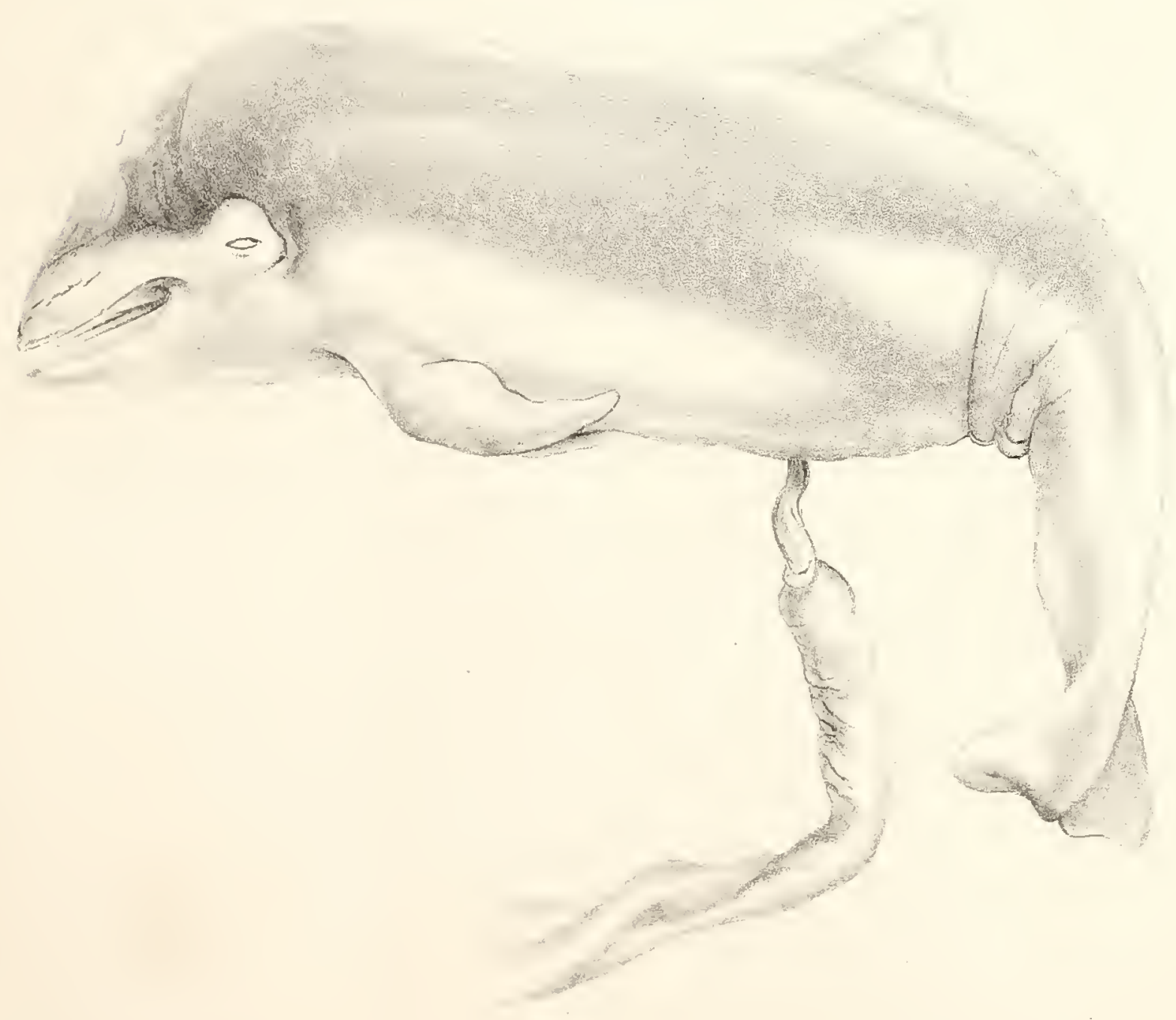



Plate IV. 


\section{The small Embryos of Phocæena communis, Less.}

Fig. 1. A 7 millim. long embryo, natural size. Fore and hind extremities risible.

2. A 17 millim. long embryo, natural size, seen from left side.

3. Same embryo. natural size, seen from rentral surface. The eyes are risible, and the double sigmoid nasal aperture, lying like a transverse fissure.

4. An 18 millim. long foetus. seen from the left side.

5. The same futus. seen from the rentral surface. The nasal aperture is here seen on a level with the eyes, and below is the broad mouth. cleft.

6. The 7 millim. long embryo. magnified 4 times, seen from the right side. The small fore-extremities and the rery small hind-extremities are noticeable, and the very long tail. The eye $(0)$ is indistinct, while the maxillary process (mx). lowel jaw. 1st risceral groove and 2nd visceral arch are distinct. Behind this last is a rounded groove, forea or sinus precervicalis. $m=$ mesencephaton; $f$. $r h=$ forea rhomboidalis; $n=$ neck-flexure; $t h=$ fore-limb: h. $\omega=$ hind limb; t. $y=$ tuberculum genitale; $u=$ umbilicus; $n s=$ the forebrain.

7. The same embryo, seen from the left side. Magnified 4 times.

8. The same embryo, seen from the back. where a raphé is visible in the middle, and somites to the sides.

9. The back of the neck of the same embryo with a rhomboidal groove, indicating fovea rhomboidalis.

10. Side view of the head of the same embryo magnified 8 times. $n=$ flexure of the back of the neck; $m=f l e x u r e ~ o f$ the crown of the head with mesencephaton; $0=$ eye; $n s=$ olfactory pits; $m x=$ maxillary process; $m b=$ lower jaw: $h y=2$ nd risceral arch: $t y=$ The forea precervicalis, with the thisd risceral arch.

11. Hearl of the same embryo. seen from the rentral surface, - the facial region. $m=$ mid-brain; $h m=$ cerebral hemispheres: $0=$ eye; $n y=$ olfactory pits on the fronto-nasal process; $l=$ boundary furrow between the maxillary process and fronto-nasal process; $m=$ maxillary process; $m b=$ lower jaw.

12. Hind part of the same embryo. magnified 16 times, and showing rudiments of hind-extremities. $u=$ umbilical cord: $\therefore u=$ vesicula umbilicalis: $m=$ proto-vertebr $; h . l$. = hind-extremity; $t g=$ tuberculum genitale.

13. The 17 millim. long embryo. magnified 4 times, seen from the iight side. $n=$ flexure of the back of the neck: f. $\mathrm{k}=$ forea rhomboidalis: $m=$ Hexure of the crown of the head with the mesencephalon; the = thal:mencephaton (supposed); $h c=$ cerebrai hemispheres; $f f^{\circ}=$ frontal furrow; $n g=$ extermal nasal aperture; $u c=$ external ear" opening: $u=$ umbilical cord; he $=$ hind extremity in a retrogressive state; $y=$ genital member.

14. Front view of the same embryo, magnified $t$ times.

15. Back view of the same embryo. magnified $t$ times. fih $=$ fovea rhomboidalis with marked lateral expansion: $i c=$ intumescentia cervicalis: $i l=$ indication of intumescentia lumbalis.

16. Sane embryo seen from the left side, magnified $t$ times.

17. The 18 millin. long furtus; front view. magnified 4 times.

18. Same fietus seen from the left side: magnified $t$ times.

19. Front view of the head of the same foetus.

20. Hinder part of the same fortus, magnified 6 times. he $=$ remains of external rudimentary hind-extremity: $y=$ genital member.

21. Right ear-opening of the same foetus. drawn by Prof. G. Guldberg with an Abbe's camera luc. obj. aa oc. 3. Figs. 1-20 from original drawings by Olaf Bergh, medical student. 

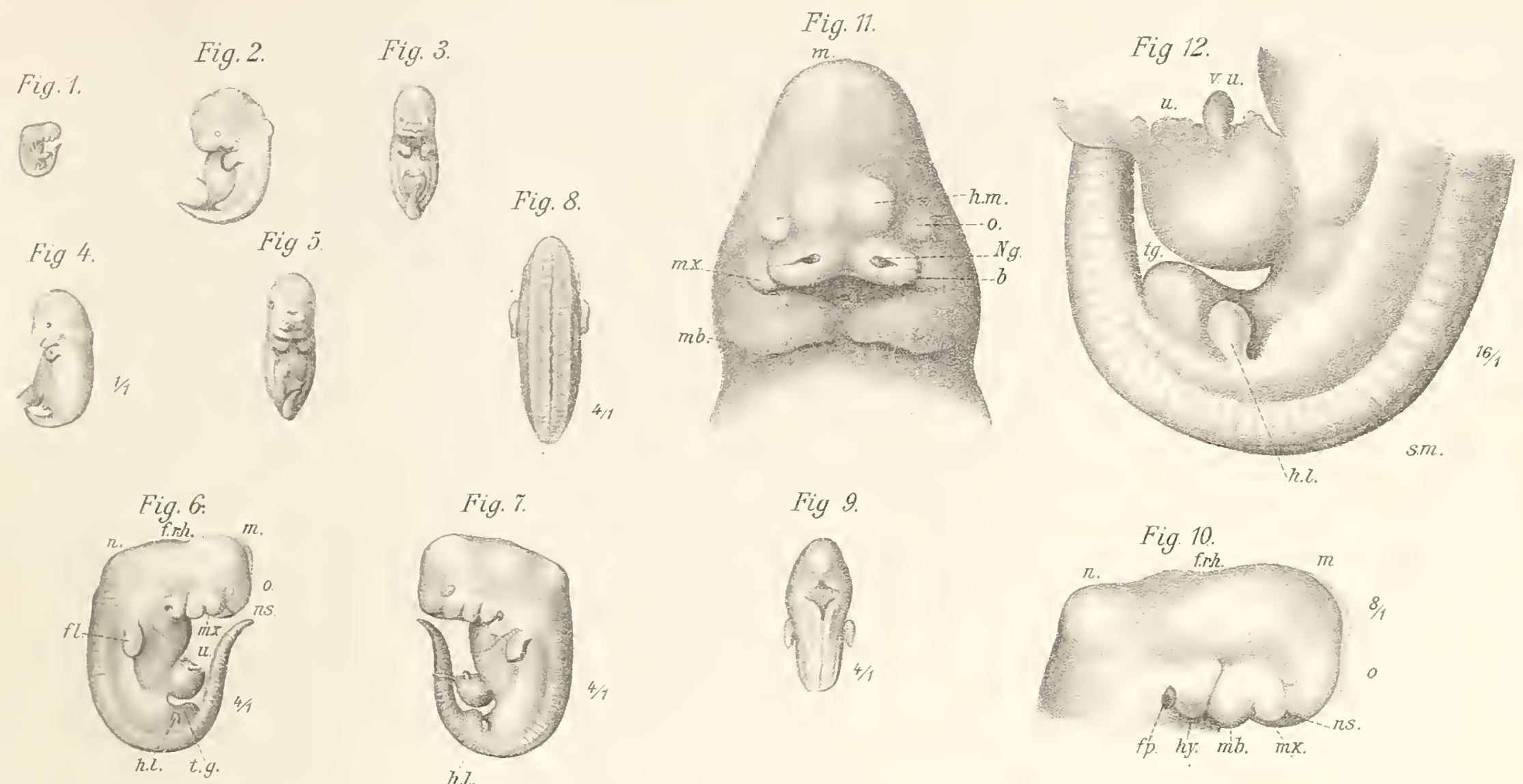

Fig. . .
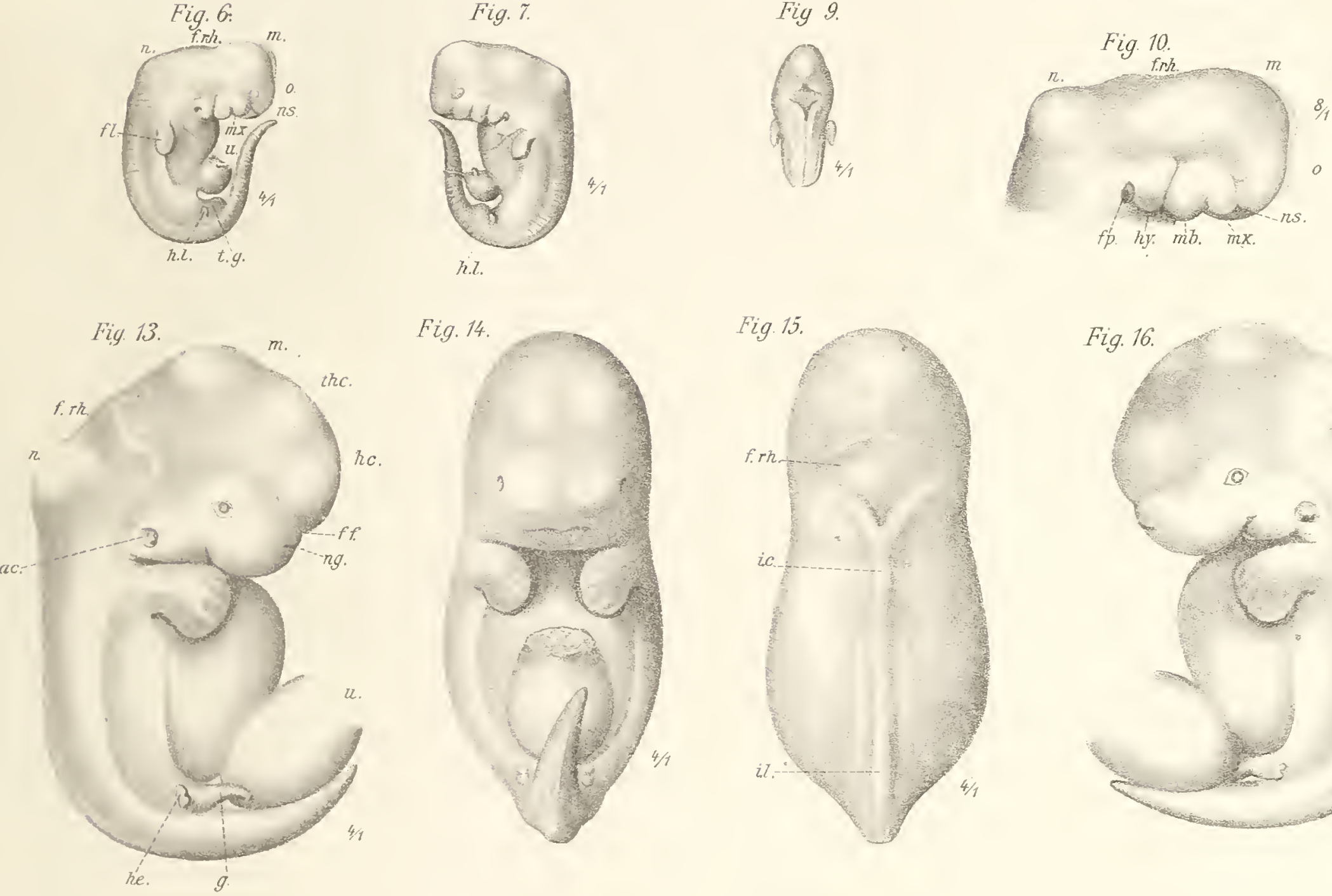

hI
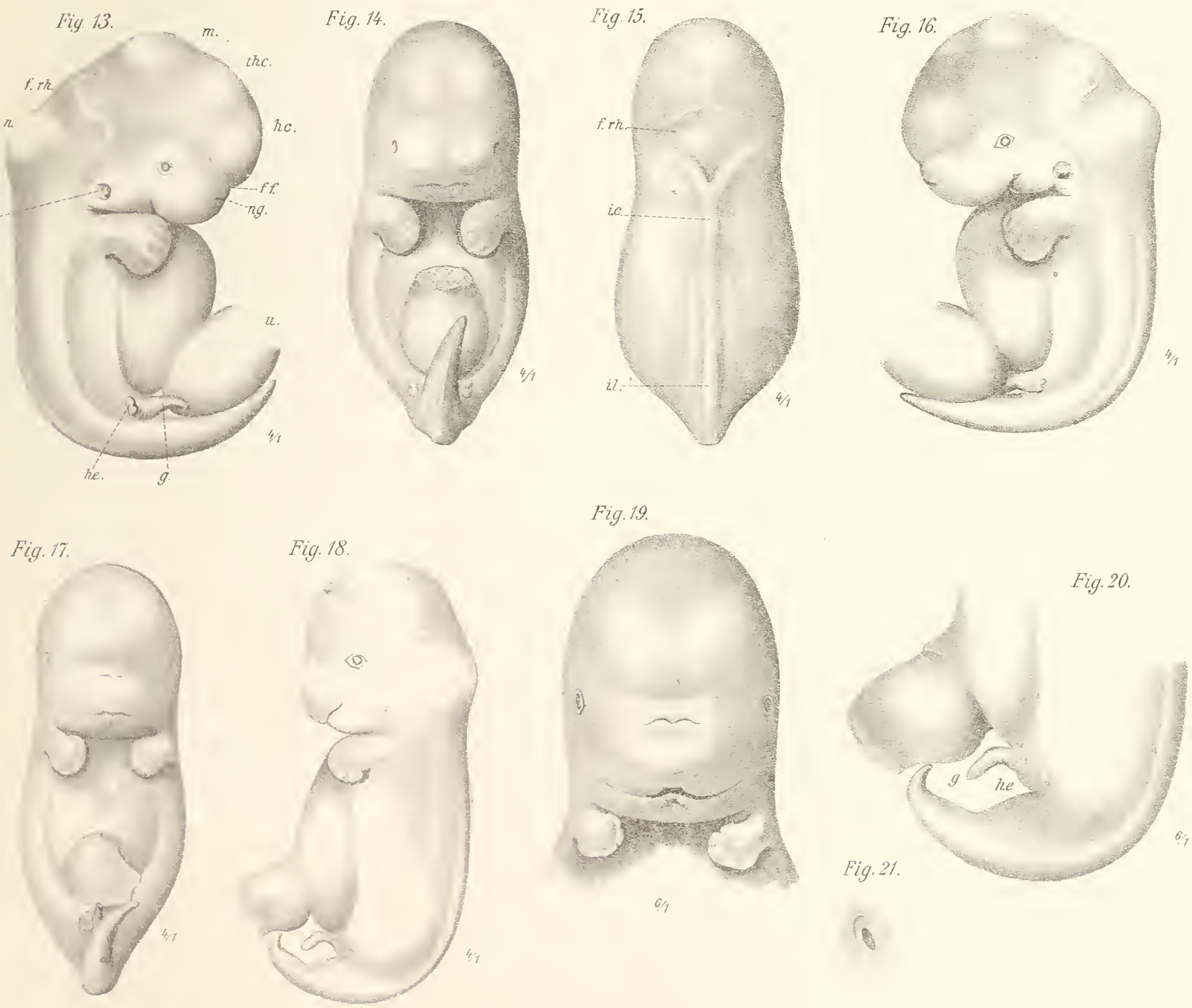

Plate V. 


\section{Foetus and newly-born young one of Orea gladiator, La Cépède.}

Fig 1. Futus fem. tos millim. long of Orca gladiator, La Cépède. The form conditions of the Orca type are distinctly seen in the short, thick snout, the broad, rounded fore-limbs, and the sharply-rising dorsal fin; and the specific characters in the distribution or dispersion of colour.

2. Tomg Orca gladiator. La Cépède, 2.51 metres long; female, between 1 and 2 months old. The outline of the newlycaptured animal was drawn by Prof. G. O. Sars, the further details by O. Bergh from the same specimen. which was stuffed and placed in the Christiania University's Zoological Collection. 

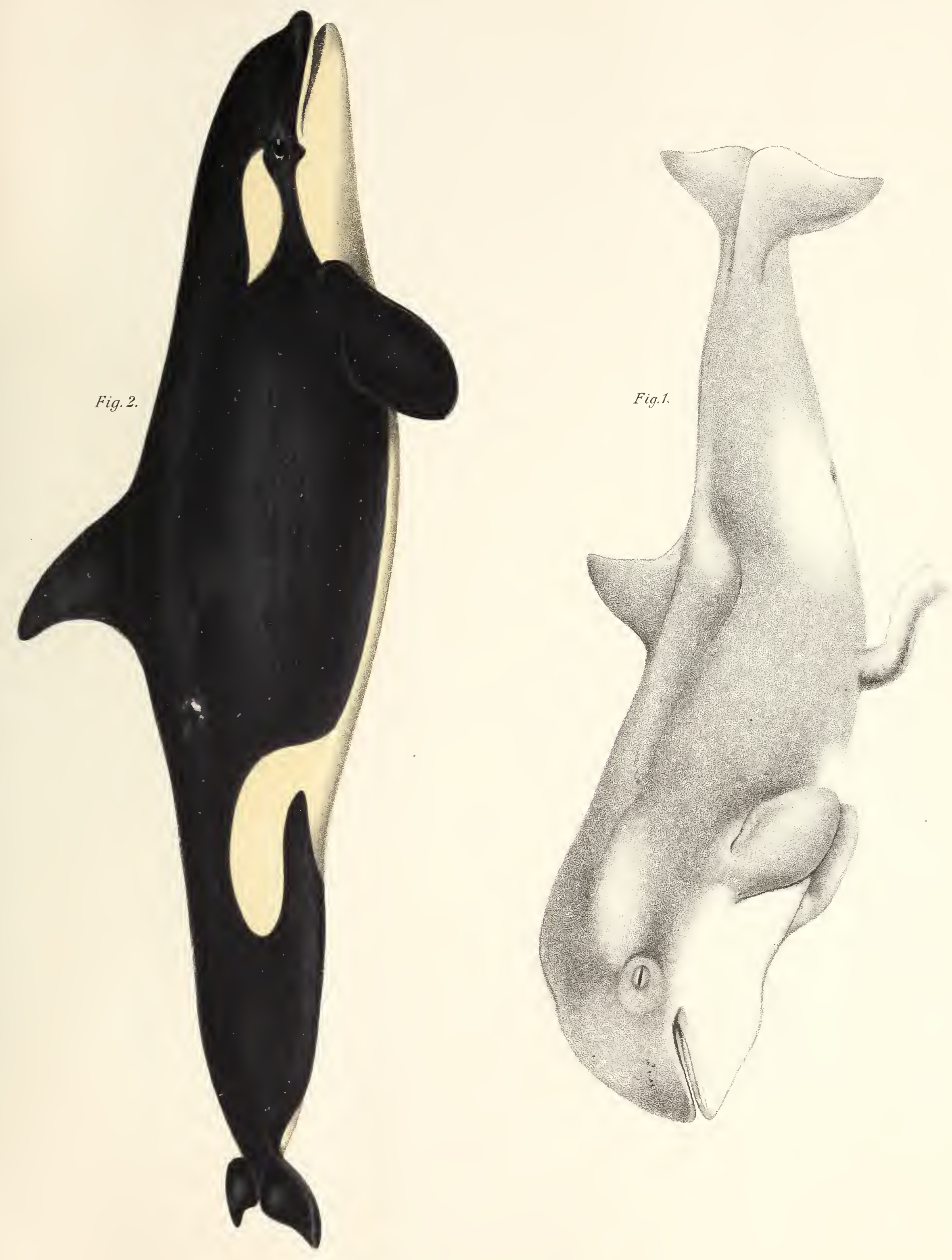

Plate VI. 


\section{Ovim and foetal membranes of Lagenorhynchus acutus, Gray.}

Fig. 1. The entire orum of Lagenorhynchus acutus, Gray, containing the 8 millim. long embryo. Natural size. Two parts are obser'rable. corresponding to the two uterine horns,

2. The same orum opened. Natural size. Drawn by Dr. F. Nansen. am = amnion with embryo; all = allantois, the broad part of it; $c h=$ chorion: $b=$ resicle-like formations; $l=$ ressel; $l i t=$ conical thickened part of a ressel.

3. Part of the same orum. enlarged $t$ times. Drawn by Olaf Bergh. $A l l=$ the expanded, leaf-like portion of the allantois covering the amnion with the embryo; $A l l=$ the opposite, thimner end of the allantois: ch = chorion: $r=$ vessel. To the left of the allantois projects the umbilical resicle. On its right, three resicle-like formations.

4. Part of the same orum. magnified 4 times. Drawn by Olaf Bergh. am $=$ amnion enreloping the embryo: the amnion contains numerous ressels. $b=$ resicle-like formations: $r, u=$ vesicula umbilicalis.

5. From the same ovum. The coarser distribution of ressels in the chorion (magnified). Drawn by Dr. F. Nansen.

6. Vesicula umbilicalis from the same orum. magnified: drawn by G. Guldberg; after it was detached from its connections. On the surface are seen small protuberances, which are indicated in the drawing by darker stripes and patches.

7. The 30 millim. Iong fuetus of Lagenorhynchus acutus. Gray. twice the natural size. Drawn by H. Bucher. jun. The foetus is enreloped in the amnion, in which fine ressels are seen; parts of the chorion and allantois are athering and rolled together. The dotted lines indicate where the amnion and the allantois were coherent.

8. The th millim. long fortus of Lagenorhychus acutus, Gray. Natural size. Drawn by H. Bucher; jun. The fortus is lying in the amnion. A portion of the other foxtal membranes is attached. The longitudinal stripes on the amnion are folds. The dotted. obliquely transverse line shows the place where the amnion and the allantois were attiched to each other. 

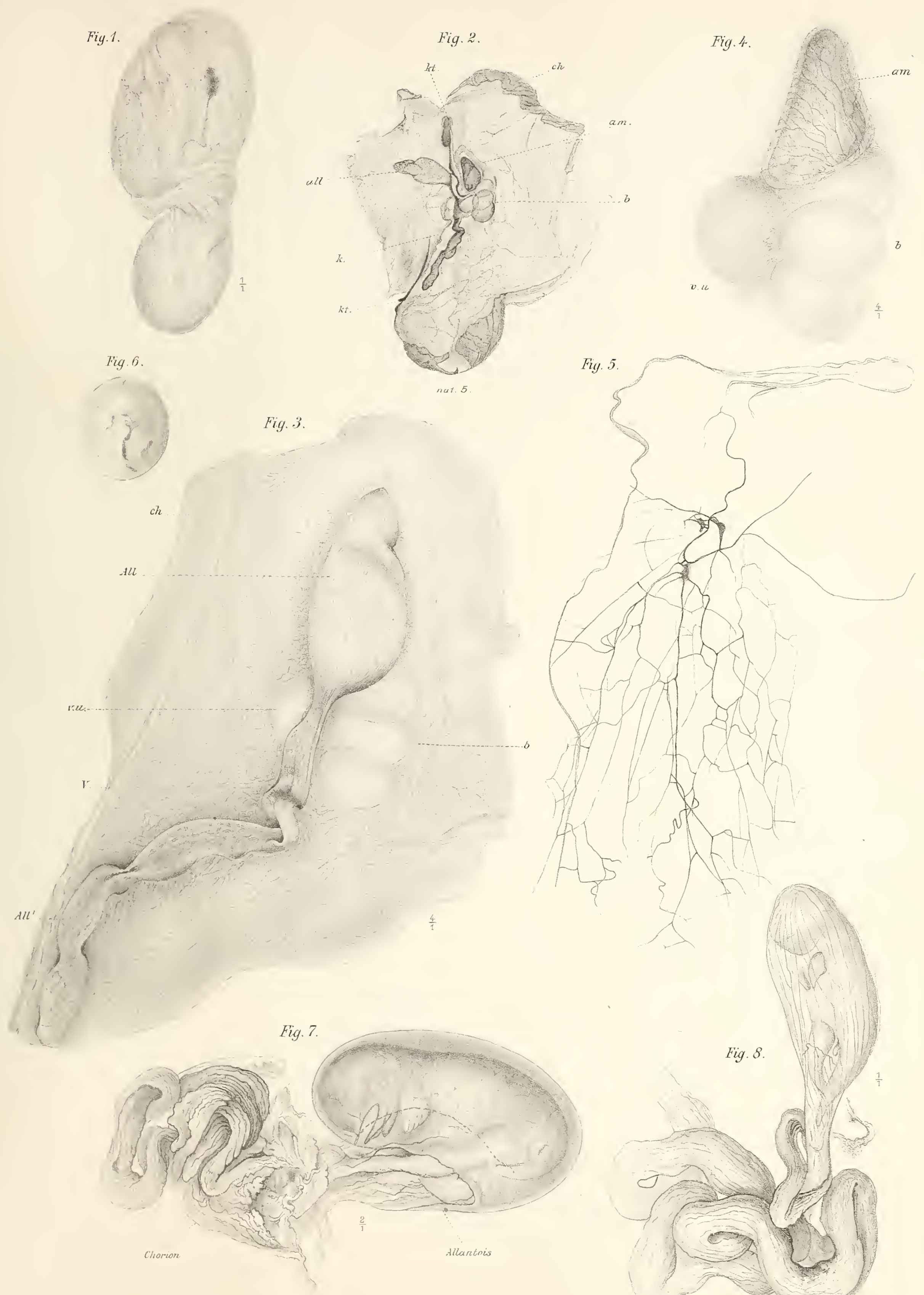

Plate VII. 


\section{Foetal membranes of Lagenorhynchus and Urea,}

Fig. 1. Tertical section through the chorion foetalis of the 75 millim. long ovum of Lagenorhynchus acutus, Gray (see Pl. YI. fig. 1). $E=$ chorionic epithelium; $B=$ connective tissue consisting of two layers with elongaterl, oral cells: $\boldsymbol{L}=$ mesenchyme, with fibrils of connectice tissue here and there: it contains capillaries, a few small reins and some wandering cells. $V_{c}=$ that part of the mesencliyme in which vacuole-like spaces occur; $\boldsymbol{M}^{1}=$ at more indifferent mesenchyme, with a few reins and wandering cells. The dotted lines, which appear like red points in the carmine-coloured specimen, probably arise from deposit of thicker albuminous matter.

2. Section of the allantois from the same orum (which contained the 8 millim. long embryo of Lagenorhynchus acutus, Gray). The contour lines drawn with an Abbes drawing-prism, Zeiss Obj. BB. Oc. 2. 'The section shows an narrow lumen, the cavity of the allantoic sac, a.l, in which the epithelium, a.e, is detached from the comnective tissue hasis, $a b$. The peripheral tissue, $a . d$, consists of spindle-shaper tissue cells. $m=$ the easily-coloured intercellular substance.

3. Section of the chorion fotalis of the 45 millim. long fretus of Lagenorlyynchus acutus, Gray; drawn with Abbes drawing-prism, Zeiss obj. a* oc. 3. The section shows a villous chorion with simple epithelium, $E$, which rests upon a thin layer of comnective tissue, beneath which is a narrow portion of mesenchyme, $M$, bounded within by the allantois, All.

4. Section through a thickening of the wall of the vesicula umbilicalis (Pl. VI, tig. 6). $i=$ interior, with "oagulated masses of albumen: $e=$ exterior'; $r=$ wall of resicle; $f=$ thickened portion of the wall of vesicle; $\mu{ }^{\circ}=$ proliferous tissue cells; $k=$ vessels; $o m=$ lumen of ductus omphalo-mesentericus with epithelial tegument, $\rho p$.

5. Transverse section of the chorion from one horn, from the 408 millim. long foetus of Orca gladiator. Natural size. $C h=$ chorion, with nmmerous longitudinal folds and small villi; all = allantoic cavity; am $=$ amniotic carity; $m s=$ partition wall formed by the allantois and amnion, where they touch each other; $v=$ transverse section of ressels in one corner of the partition wall.

6. rection of the chorion from the above named feetus of Orca gladiator, drawn with an Abbe's drawing-prism, Keiss obj. $a^{*}$ oc. 2. The rillous excrescences of the chorion are visible with their simple epithelium. ve $=$ villous excrescences: $e=$ chorionic epithelium: $l=$ connective tissue; $m=$ mesenchyme; $k, k=$ small ressels and capillaries in the rilli; $k^{*} k^{\prime \prime}=$ transverse section of larger vessels; $a l l=$ allantoic cavity; $a m=$ amniotic carity.

(Figs. 1, 5 and 6 are drawn by Olaf Bergh, medical student; tigs. 2, 3 and 4 by the author, G. Guldherg). 

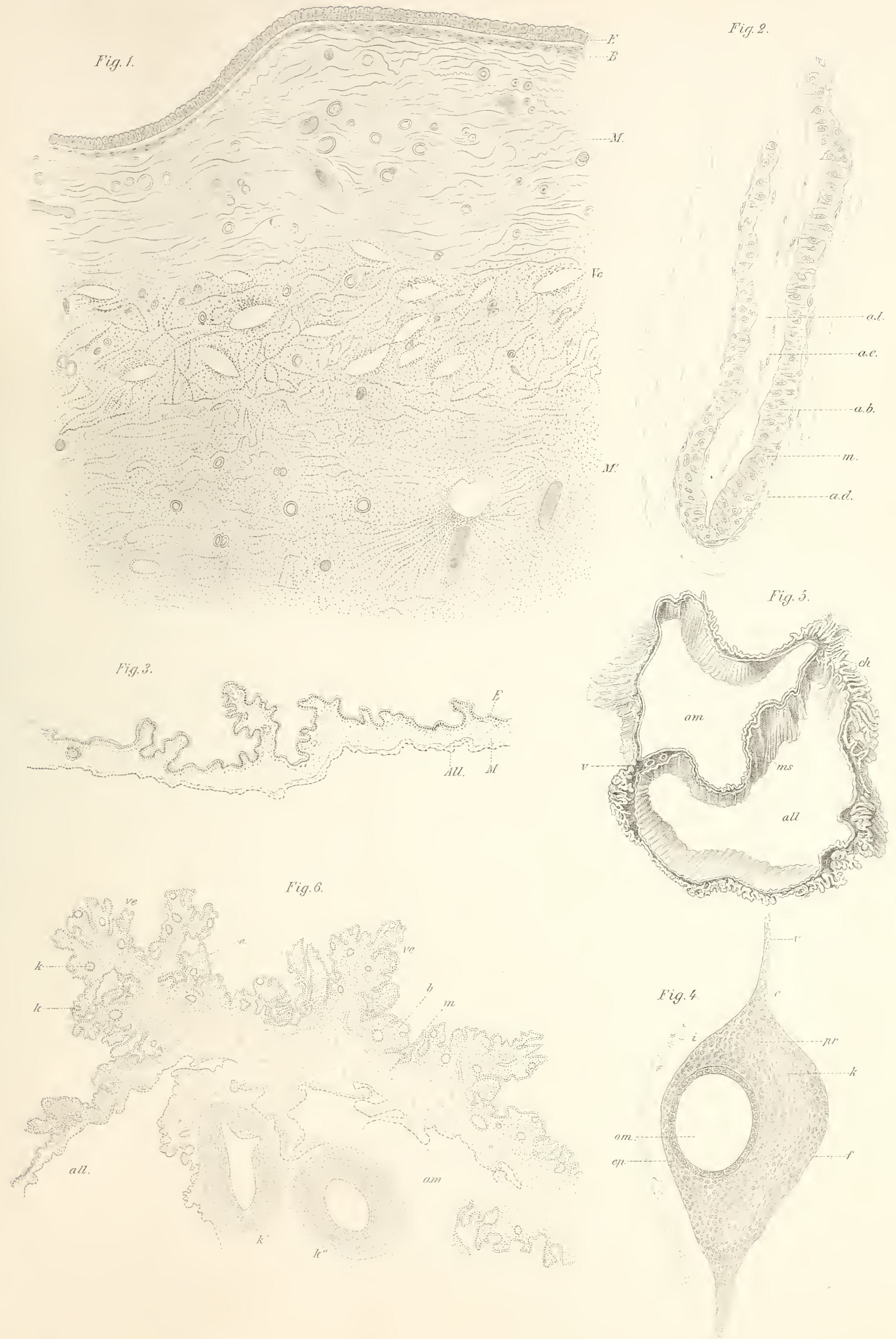







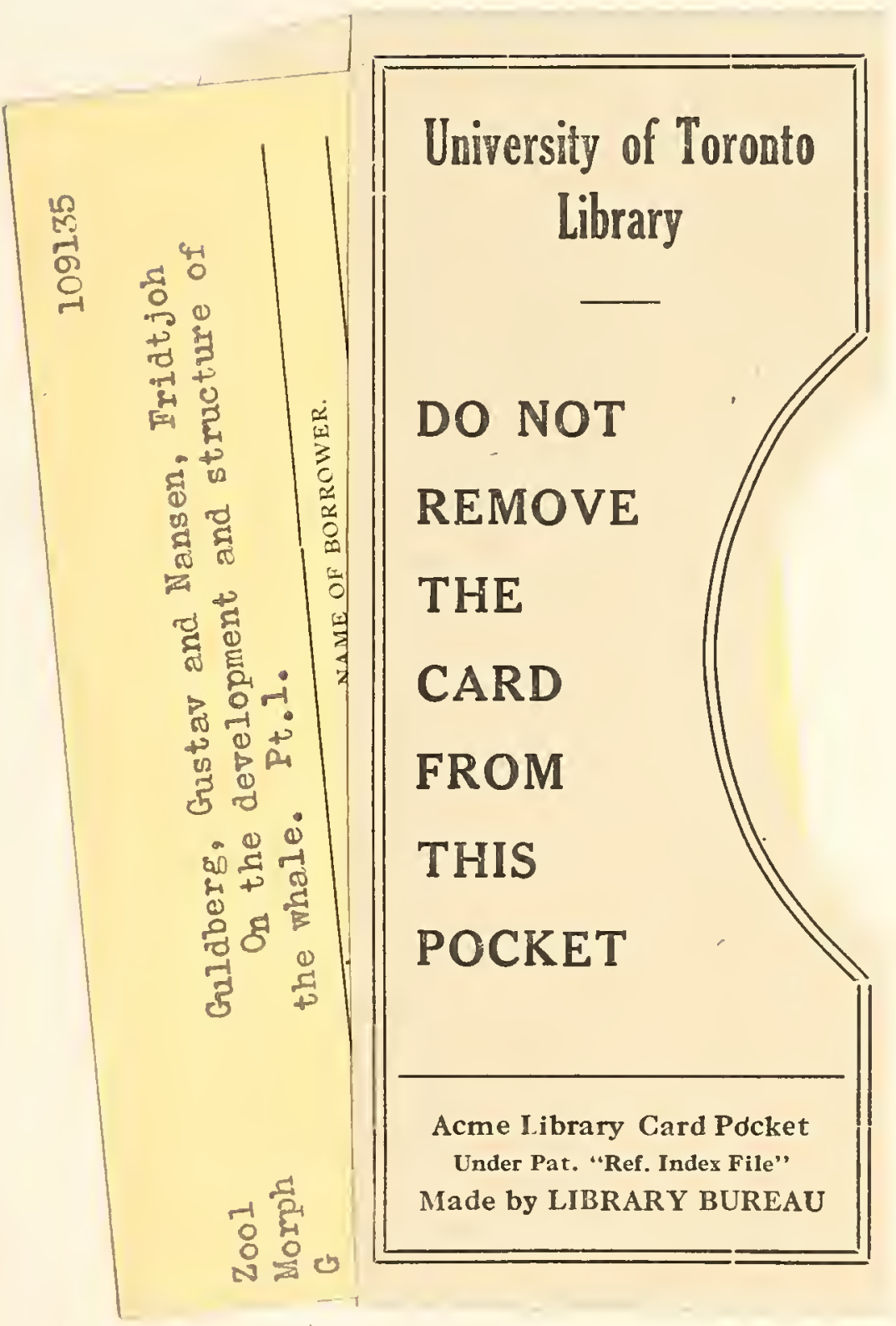




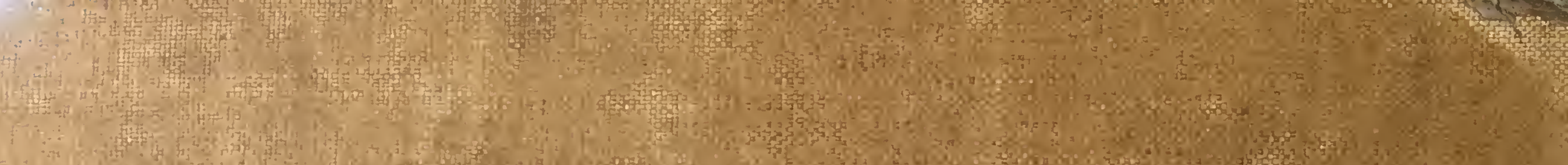

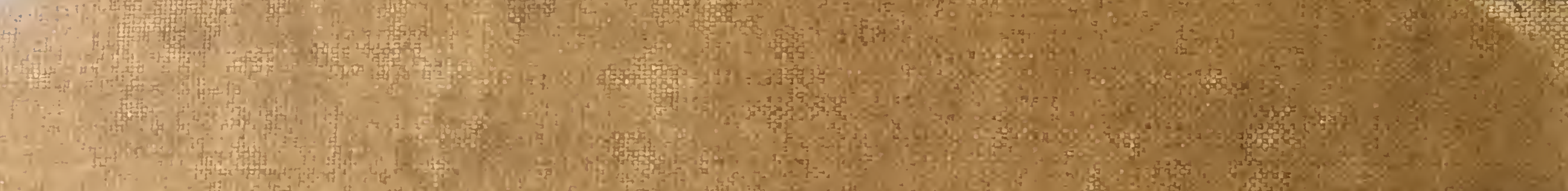

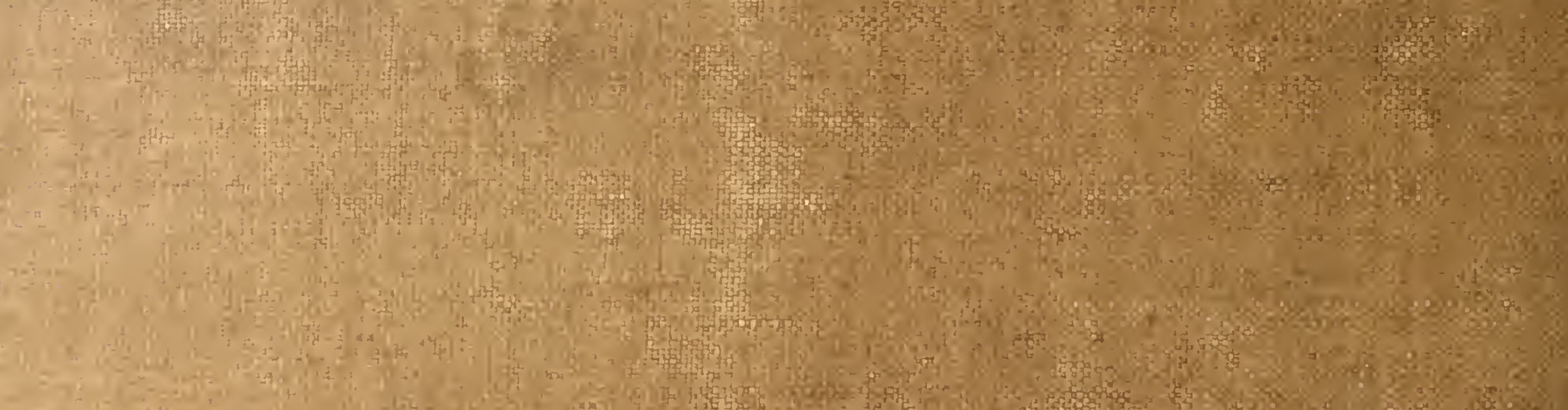

4 1. Q

10.

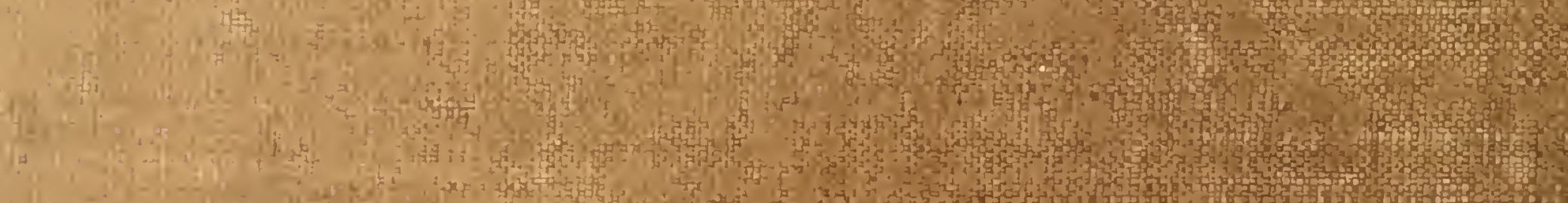

(7)

8.

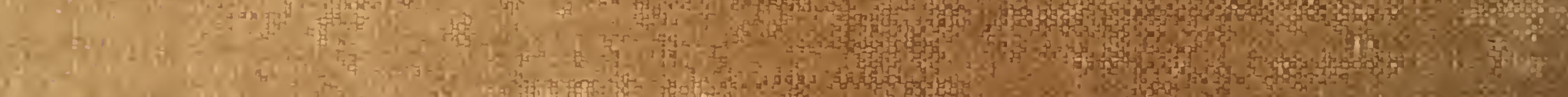

(1)

int

20.

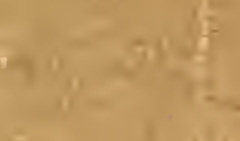

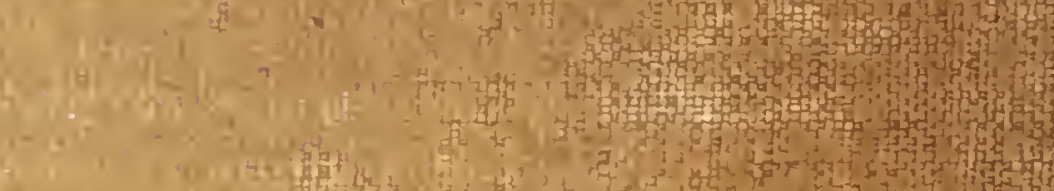

a chints

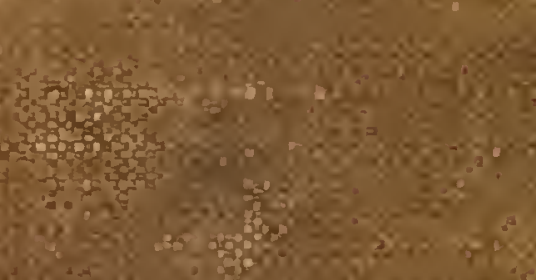

H.

C.

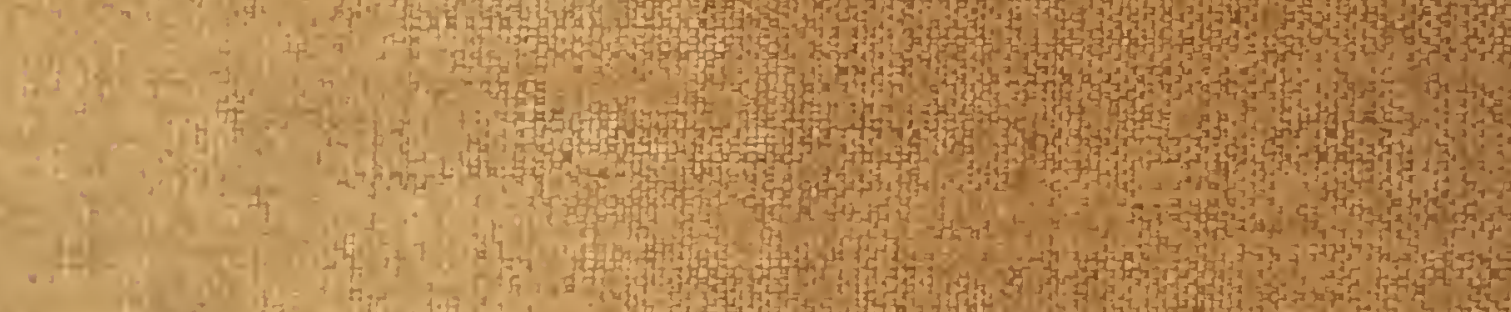

(1)

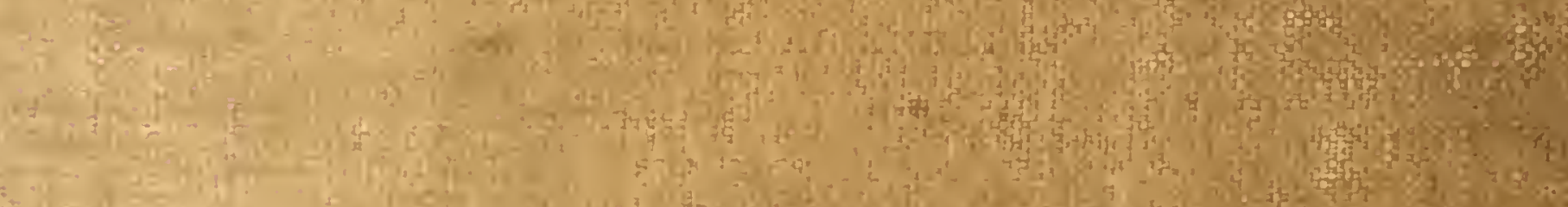

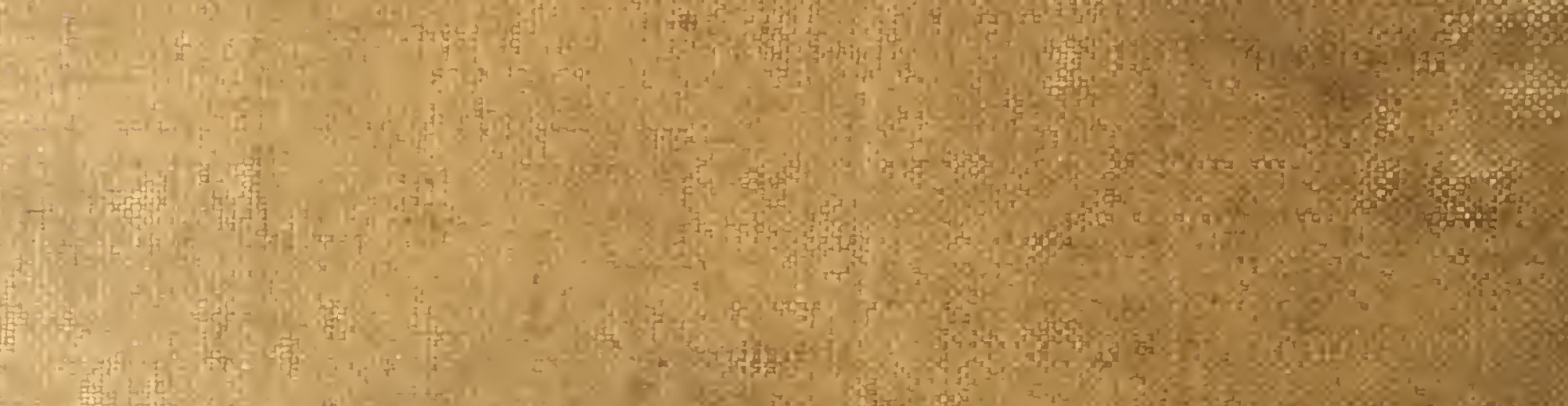

年 